\title{
Numerical Taxonomy of Some Nocardioform Bacteria
}

\author{
By M. GOODFELLOW \\ Department of Microbiology, The University Medical School, \\ Newcastle upon Tyne, NEI ${ }_{7} R U$
}

(Accepted for publication 9 August I97I)

\begin{abstract}
SUMMAR Y
A collection of 283 nocardioform bacteria was studied by means of $24 \mathrm{I}$ tests which included many biochemical, physiological and nutritional characters. The results were subjected to computer analysis in which two coefficients of association and two cluster-analysis techniques were used. Single linkage and average linkage cluster analysis gave almost identical results, but with the simple matching coefficient a few strains were grouped together on the basis of shared negative correlations. With the matching coefficient I 5 clusters were formed whereas with the similarity coefficient there were I8. In each analysis the seven major clusters corresponded to (I) Nocardia asteroides, (2) Nocardia caviae, (3) Nocardia brasiliensis, (4) Actinomadura madurae, (5) Actinomadura pelletieri, (6) Oerskovia turbata, (7) the rhodochrous complex. The data revealed many new characters which could be weighted for identification. The clusters and subgroups were therefore readily distinguished from one another by several unrelated phenotypic characters.
\end{abstract}

\section{INTRODUCTION}

Bacteria which produce a mycelium that fragments into rods and cocci have been referred to by the term nocardioform (Prauser, 1967). Many of these organisms are classified in the genus Nocardia, others as species of Mycobacterium. Nevertheless, great difficulty is found in characterizing nocardioform bacteria as so few good characters are available for identification. This paper presents detailed taxonomic information which shows that a large number of nocardioform organisms fall into only a few clusters, readily defined by several unrelated phenotypic characters. Some of the clusters appeared to warrant recognition as genera, others as species.

No taxonomist would consider the genus Nocardia to be well defined. The introduction to the genus in the 7 th edition of Bergey's Manual of Determinative Bacteriology (I957) is long, imprecise and rests heavily on the assumption that nocardiae form a well-defined mycelium which, sooner or later, fragments completely. Bacteriologists and mycologists have assigned to Nocardia all kinds of bacteria which exhibit fragmenting mycelia, often without regard to other criteria. Fragmentation is not always easy to recognize and may often be a strain characteristic. It is not surprising, therefore, that the genus is heterogeneous and contains species which should be transferred to such established genera as Micromonospora, Mycobacterium and Streptomyces or be included in the recently proposed genera Actinomadura (Lechevalier \& Lechevalier, 1970) and Oerskovia (Prauser, Lechevalier \& Lechevalier, I970). It is clear that the genus requires drastic taxonomic revision and that future changes need to be based upon evidence more substantial than that used in the past.

Forty-four species of Nocardia are described in the last edition of Bergey's Manual ( I957). 
Many of the species are inadequately defined and differentiation is difficult if not impossible. In diagnostic keys a lot of weight is given to acid-fastness, to pigmentation and to morphological characters, properties considered to have a diagnostic value for the genera Mycobacterium and Streptomyces. With the nocardiae these characters have frequently been shown to be unsuitable, and reliance on them has tended to confuse rather than clarify the classification of the genus. Gordon (1966a) and Gordon \& Mihm (1957, 1959a, 1962 a, b) have developed a battery of tests to define and differentiate between the five well-known pathogenic species of Nocardia, and they reduced a number of nomenspecies to synonyms of these. The intraspecific variation patterns and the quantitative relationships between even these better-known species remain obscure.

The variability that nocardiae show towards some of the biochemical and staining tests encouraged the application of other techniques in attempts to resolve the taxonomic difficulties. Representative strains have been used in phage-typing and serological studies (Prauser \& Falta, I968; Kwapinski, I970), in wall composition studies (Yamaguchi, I965; Lechevalier \& Lechevalier, 1971), and in the study of whole organism lipid patterns (Mordarska \& Mordarski, I969; Lechevalier, Horan \& Lechevalier, 197r). The results of studies such as these have allowed the separation of nocardiae into broad groups of related strains but a reliable classification of the genus remains to be generally accepted. It was for this reason that an extensive comparative study of a large number of phenotypic characters of nocardiae and closely related organisms was undertaken.

In systematic studies it is important that sufficient strains of each taxon be taken to provide reasonable assurance that specific patterns of reactions will be detected. A list of all the legitimately described species of Nocardia was therefore compiled (Buchanan, Holt \& Lessel, I966), and the test material included where possible the type strain of each species, and organisms thought to represent the range of variation shown within the species. It was not possible to obtain cultures of 13 of the species described in Bergey's Manual (1957). In addition to the named strains, nocardiae isolated from soil, silage, sea and fresh water, and other nocardioform bacteria of uncertain taxonomic status were studied. Prominent amongst the latter were strains received as Mycobacterium rhodochrous (Gordon, 1966b). Finally, marker strains representing genera taxonomically related to Nocardia were included for comparison.

In studies with diverse groups of bacteria there is the problem of the general relevance of characters. In this study, group formation was based upon as many good characters as it was practical to handle. It was hoped that the $24 \mathrm{I}$ characters chosen reflected the spectrum of an organism's potential phenotypic attributes. Several characters, notably some chemotaxonomic ones, known to have a diagnostic value (Lechevalier \& Lechevalier, 1971) were not studied because of the difficulty in collecting such data from a large number of bacteria. A few of the classical tests were included for continuity, and so were some of the characters found useful by Gordon (1967). There was, however, no conscious bias in test selection. Many of the tests were applied to nocardioform bacteria for the first time or, if used previously, had only been studied with a few strains. In particular, the bacteria were screened to see if they could use a range of sole carbon sources for their growth and energy requirements. Like pseudomonads, nocardioform bacteria are thought to be nutritionally versatile and able to use a wide range of organic compounds for their energy requirements (McClung, 1954; Clark \& Hittle, 1962). Recently Raymond, Jamison \& Hudson (1967) observed that nocardiae can oxidize methyl-substituted mono and dicyclic aromatic hydrocarbons, and Jones \& Edington (r968) isolated nocardiae from soil which were able to oxidize $n$-octane, $n$-dodecane and cyclohexane. The inclusion of such nutritional tests was considered to be 
justified because, as with the pseudomonads (Stanier, Palleroni \& Doudoroff, I966), some of these characters may have an important diagnostic value.

All the characters studied were given equal weight and the strains were classified on the basis of general similarity. Since nocardioform bacteria have not been subjected to an exhaustive systematic comparative study, there is no evidence on which to build a case for differential weighting. In a preliminary limited numerical taxonomic study I found that it was possible to detect clusters of nocardiae which could be defined by a few independent and highly correlated characters. During the course of this study other computer analyses based on Adansonian principles have been applied to the genus Nocardia with varying degrees of success (Cerbón, 1967; Tsukamura, 1969). An extended numerical taxonomic study in which the characters were given equal weight was therefore considered justified.

It was hoped that improved classification of the nocardioform bacteria would lead to the exclusion from the genus Nocardia of taxonomically unrelated forms and leave a homogeneous taxon, readily differentiated from allied taxa. Another aim was to try and resolve the taxonomic status of the Mycobacterium rhodochrous complex which to date has proved resistant to taxonomic analyses. In addition, it might be possible to ascertain the range of variation within clusters and the quantitative relationships between them. In this way heterogeneous clusters would be spotlighted?and provide the subject matter for further specialized studies. Finally, representatives could be chosen rationally to represent defined clusters for use in experiments too lengthy for routine work with many strains.

\section{Strains}

METHODS

Nearly all of the 283 organisms were received from public or private culture collections. They included the readily available type or neotype strains of the genus Nocardia. In addition to representatives of the better-known species, saprophytic strains of nocardiae isolated from a variety of habitats were studied. Details of the source, past histories,'culture collection numbers, etc., of all these strains are given in the results section (Tables 3 to I3). The nocardioform strains carried nine generic epithets. The Nocardia strains were received under 37 specific names. On arrival each strain was given a serial number $(\mathrm{N} \mathrm{I} \rightarrow \mathrm{N} n)$, and the name under which it was received retained.

Initially all the organisms were examined for purity and for their ability to grow on yeast extract agar (YEA). This basal medium proved to be suitable and all strains were maintained on YEA slopes at room temperature, at $4^{\circ}$ and at $-20^{\circ}$. For long-term storage the organisms were lyophilized.

\section{Collection of data}

For each strain 24I features were studied. All test media were inoculated from I4-day-old cultures grown at $30^{\circ}$ on YEA or in yeast extract broth. Unless otherwise stated test media were incubated at $30^{\circ}$ for 14 days. Tests were generally carried out once, but always repeated when inconclusive results were obtained. Many of the tests were performed in divided polystyrene Replidishes. Each dish is divided into 25 separate compartments and can be readily inoculated by means of a simple multipoint inoculator (Sneath \& Stevens, 1967). Tests which required prolonged incubation, or entailed production of gaseous or volatile compounds or the measurement of the zones of clearing of insoluble compounds were performed in tubes or Petri dishes. The 204 unit characters scored for computation are listed in Table I. The tests are described below. 
Table I. Unit characters for which all organisms were examined

No. of
states

Presence of

Mycelium

Permanent mycelium

Rods and cocci

Only rods

Only cocci

Aerial hyphae*

Diffusible exopigment

Acid-fast reaction*

Colony

Margin

Elevation

Pigmentation

Easy to emulsify

Suspension coarse

Production of acid from

L-Arabinose

D-Arabinose

D-Xylose

L-Rhamnose

D-Fructose

D-Galactose

D-Glucose (aerobically)

Mannose

Cellobiose

Lactose

Sucrose

Maltose

Trehalose

Melezitose

Raffinose

Glycogen

Inulin

Amygdalin

Arbutin

Salicin

Adonitol

Dulcitol

Glycerol

Mannitol

Sorbitol

Inositol

Glucose (anaerobically)

Ethanol

Dextrin

Hydrolysis of

Adenine*

Aesculin

Casein*

Cellulose

Chitin

DNA

Gelatin*

Guanine

Hippurate

Hypoxanthine*

Keratin*

No. of
states

Character states

Hydrolysis of

Tween 20

Tween 40

Tween 60

Tween 80

Tyrosine*

Xanthine*

Xylan

Character

states

Production of

Allantoinase*

Catalase, strong

$m$-Nitrophenoloxidase

$p$-Nitrophenoloxidase

Oxidase

Urease*

Reduction of nitrate

Benzidine test*

Utilization, as sole carbon source, of

The sugars, sugar alcohols

Starch

Glucosamine

Sodium acetate

Sodium- $n$-butyrate

Sodium propionate

Sodium- $n$-octoate

Adipic acid

Pimelic acid

Sebacic acid

Sodium succinate

Sodium- $H$-malate

Sodium malonate

Sodium benzoate

Testosterone

$m$-Hydroxybenzoic acid

$p$-Hydroxybenzoic acid

L- $\alpha$-Alanine

$D-\alpha$-Alanine

DL-nor-Leucine

L-Threonine

L-Tryptophan

L-Tyrosine

L-Proline

Betaine $\mathrm{HCl}$

Acetamide

Sodium lactate

Sodium tartrate

Sodium citrate

Sodium pyruvate

Benzamide

Sodium hippurate

Sodium gluconate

Protocatechuic acid

L-Serine

p-Cresol

$o$-Hydroxybenzaldehyde

D-Mandelic acid

Liquid paraffin

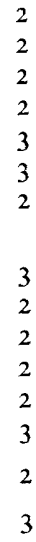

3

52

2

2

2

2

2

2

2

2

2

2

2

2

2

2

2

2

2

2

2

2

2

2

2

2

2

2

2

2

2

2

2

2

2

2

2

2

2 
Table I (cont.)

\begin{tabular}{|c|c|c|c|}
\hline Character & $\begin{array}{l}\text { No. of } \\
\text { states }\end{array}$ & Character & $\begin{array}{l}\text { No. of } \\
\text { states }\end{array}$ \\
\hline Utilization, as sole carbon and nitrogen & & Resistance to & \\
\hline source, of & & Phenyl ethanol* & 5 \\
\hline Acetamide & 2 & Potassium tellurite* & 5 \\
\hline Serine & 2 & Sodium azide* & 5 \\
\hline Trimethyldiamine & 2 & Sodium chloride* & 5 \\
\hline Resistance to & & Teepol* & 4 \\
\hline Lysozyme & 2 & Tetrazolium* & 3 \\
\hline Penicillin & 2 & Thallous acetate* & 4 \\
\hline Bismuth citrate* & 4 & Thermotolerance* & 6 \\
\hline Crystal violet* & 5 & & \\
\hline Phenol* & 4 & Acid tolerance* & 6 \\
\hline
\end{tabular}

Bacterium morphology and staining properties. Smears from YEA slopes showing good growth were prepared, Gram-stained by means of Hucker's modification (Society of American Bacteriologists, I957), and examined for the presence of a mycelium, fragmentation, pleomorphism, etc. On arrival all strains were stained by a modification of the ZiehlNeelson method (Gordon, 1967) and the degree of acid-fastness noted. Motility was detected in hanging drop preparations, and in Craigie tubes containing sloppy YEA (Society of American Bacteriologists, I957).

Colony characters. The morphology of the hyphae and their fragmentation were observed by means of a Watson Stereozoom microscope at $\times 50$ after I, 3 and 7 days growth on YEA plates. The same plates were examined after 7 and $\mathrm{I} 4$ days for colonial features, pigmentation, detection of water-soluble exopigments, aerial hyphae, etc. With butyrous or 'soft' growing nocardioform organisms aerial hyphae production tended to be sparse and could be seen only by focusing on the colony surface. Finally the texture of the colony and ease with which it could be emulsified were recorded.

Fermentation studies. The basal medium of Juhasz \& Bönicke (I965) was amended with $0.03 \%(\mathrm{w} / \mathrm{v})$ bromothymol blue. The concentration of the indicator was less than that recommended by Hugh \& Leifson (1953) but did not inhibit the growth of any strains. Inoculated tubes were incubated for three weeks and acid production detected by a change in colour of the medium. With glucose the test was done in duplicate, one tube being sealed with a I cm. layer of vaspar. Sterile sugars and sugar alcohols were added to the basal medium to give a final concentration of $I \%(w / v)$. Dulcitol, dextrin and inulin were steamed for $\mathrm{I} h$. on three successive days. The remaining carbohydrates were sterilized by filtration. The carbohydrates used are tabulated in Table $\mathrm{I}$.

Hydrolysis of organic compounds. The hydrolysis of adenine, xanthine, hypoxanthine, tyrosine, guanine $(0.2 \%, \mathrm{w} / \mathrm{v})$, keratin $(0.2 \%, \mathrm{w} / \mathrm{v})$ and xylan $(0.4 \%, \mathrm{w} / \mathrm{v})$ was detected in the basal medium described by Gordon (1967), and chitin degradation in the medium devised by Veldkamp (I955). The plates were heavily inoculated and observed for the disappearance of the insoluble compounds. Zones of clearing greater than $4 \mathrm{~mm}$. were scored as strong positives. Guanine and chitin plates were read weekly for five weeks, the rest for three weeks. The hydrolysis of casein and gelatin was examined by means of the medium and method described by Gordon (I967). The production of deoxyribonucleases was detected in YEA amended with $0.2 \%(\mathrm{w} / \mathrm{v})$ deoxyribonucleic acid, by means of the method of Jeffries, Holtman \& Guse (I957). Hippurate hydrolysis was studied in tubes containing the 
medium recommended by Gordon \& Horan (I968). After six weeks' incubation a positive result was indicated by the appearance of benzoic acid crystals after an equal volume of $50 \%$ sulphuric acid had been added to the medium. Degradation of cellulose strips in YE broth was also observed after six weeks incubation. Tweens $20,40,60$ and 80 were incorporated into the medium recommended by Sierra (1957) and the media examined for the production of extracellular lipases. Opacity around the areas of growth due to the precipitation of calcium salts was recorded as a positive result. These tests and the detection of aesculin hydrolysis (Sneath, 1966) were carried out in Replidishes.

Organic compounds as sole sources of carbon and energy for growth. Preliminary experiments were designed to find a suitable basal medium for these nutritional studies. Three Replidishes of each of the eight basal media were prepared, one amended with $\mathrm{I} \%(\mathrm{w} / \mathrm{v})$ glucose and a second with $0.1 \%(\mathrm{w} / \mathrm{v})$ sodium citrate. The third dish was the control and contained no carbon source. The basal media tested were those of Pridham \& Gottlieb (I948), McClung (1954), Gordon \& Mihm (I957), Jones \& Bradley (I964), Juhasz \& Bönicke (1965), Stanier, Palleroni \& Doudoroff (I966), Stevenson (I967) and Jones \& Edington (I968). The prepared dishes were inoculated with 25 randomly selected nocardioform organisms. Only two of the media consistently supported good growth of the test strains together with negligible background growth on control dishes. The basal medium of Stanier et al. (I966) was rejected in favour of that of Stevenson (1967), which is much easier to prepare.

The selected basal medium contained 'Bacto Yeast Nitrogen Base w/o amino acids' (Difco Laboratories) to which Ionagar and $10.0 \mathrm{mg}$. Casamino acids/l. were added. Before this mixture was dispensed $800 \mathrm{ml}$. amounts were neutralized with $200 \mathrm{ml}$. sterile $\mathrm{I} \%$ $(\mathrm{w} / \mathrm{v}) \mathrm{K}_{2} \mathrm{HPO}_{4}$. Most of the organic salts were sterilized separately by autoclaving and added to the basal medium at the appropriate concentration. If the thermostability of a compound was in doubt, sterilization was by filtration. The sugars and sugar alcohols were sterilized as before.

The inoculated Replidishes were scored visually after 7 and I4 days. There were two control plates; one contained the basal medium without any carbon source, the second basal medium plus $0.1 \%(\mathrm{w} / \mathrm{v})$ glucose. A positive result was registered if growth in the test dish was greater than in the control dish without the carbon source, and negative where growth was equal to or less than that on the control plate. Spurious negative results were spotted when test plates were compared with control plates containing glucose. Inconclusive results were rare, provisionally scored \pm , and repeated. For the first 40 tests duplicate dishes were prepared but the results were in such good agreement that this practice was discontinued.

The concentration of the different carbon sources in the basal medium varied. The final concentration was intended to be sufficient to avoid substrate exhaustion but not enough to inhibit the growth of any of the strains. The I02 high-purity compounds listed below were examined as sources of carbon and energy for growth.

(a) Carbohydrates and sugar derivatives $(\mathrm{I} \%, \mathrm{w} / \mathrm{v})$ : L-arabinose, D-arabinose, D-xylose, L-rhamnose, D-fructose, D-galactose, D-glucose, D-mannose, cellobiose, lactose, sucrose, maltose, trehalose, melezitose, raffinose, glycogen, inulin, amygdalin, arbutin, salicin, dextrin, starch, glucosamine, gluconate.

(b) Polyalcohols and glycols $(\mathrm{r} \%, \mathrm{w} / \mathrm{v})$ : adonitol, dulcitol, glycerol, mannitol, mesoinositol, sorbitol.

(c) Fatty acids $(0 \cdot \mathrm{I} \%, \mathrm{w} / \mathrm{v})$ : sodium formate, acetate, propionate, $n$-butyrate, $n$-octoate, $H$-malate, pelargonic acid. 
(d) Dicarboxylic acids $(0.1 \%, \mathrm{w} / \mathrm{v}): \mathrm{I}$, saturated: sodium oxalate, malonate, succinate, adipic acid, pimelic acid, sebacic acid; 2 , unsaturated: sodium fumarate.

(e) Aliphatic amino acids $(0 \cdot \mathrm{I} \%, \mathrm{w} / \mathrm{v}): \mathrm{D}-\alpha$-alanine, $\mathrm{L}-\alpha$-alanine, DL-arginine $\mathrm{HCl}$, DL-nor-leucine, L-threonine, DL-ornithine, L-serine.

( $f$ ) Amino acids with a ring structure $(0.1 \%$ w $/ v):$ L-tryptophan, D-tryptophan, Lproline, L-tyrosine.

(g) Amines $(0 \cdot 1 \%, \mathrm{w} / \mathrm{v})$ : histamine, putrescine.

(h) Hydroxyacids $(0 . \mathrm{I} \%, \mathrm{w} / \mathrm{v})$ : sodium citrate, lactate, D-tartrate.

(i) Aromatic acids, $0 \cdot \mathrm{I} \%(\mathrm{w} / \mathrm{v})$ : sodium hippurate, $o$-hydroxybenzoic acid, $m$-hydroxybenzoic acid, $p$-hydroxybenzoic acid, D-mandelic acid, L-mandelic acid, 0 -nitrobenzoic acid, phenylglyoxylic acid, protocatechuic acid, shikimic acid; $0.05 \%(\mathrm{w} / \mathrm{v})$ : anthranilic acid, genistic acid, nicotinic acid, phthalic acid, syringic acid, vanillic acid; $0.01 \%(\mathrm{w} / \mathrm{v})$ : quinic acid.

(j) Phenols and phenolic derivatives and homologues, $0.025 \%(\mathrm{w} / \mathrm{v})$ : catechol, $o$-nitrophenol, $m$-nitrophenol, $p$-nitrophenol; $0.05 \%$ (w/v): p-cresol.

(k) Steroids (o. I \%, w/v): indole-3-acetic acid, testosterone.

(l) Polynuclear aromatics $(0 \cdot 1 \%, \mathrm{w} / \mathrm{v})$ : naphthalene.

(m) Monobasic acid with the carboxyl group in the side-chain $(0.025 \%, \mathrm{w} / \mathrm{v})$ : cinnamic acid.

(n) Aromatic aldehydes, $0.025 \%(\mathrm{w} / \mathrm{v})$ : syringaldehyde; $0.05 \%(\mathrm{w} / \mathrm{v})$ : vanillin.

(o) Keto acids $(0 . \mathrm{I} \%$, w/v): sodium pyruvate.

( p) Miscellaneous non-nitrogenous aromatic compounds, $0 \cdot \mathrm{I} \%(\mathrm{w} / \mathrm{v})$ : sodium alginate benzoyl-formate, benzoate, mucic acid; $0.05 \%(\mathrm{w} / \mathrm{v})$ : ferulic acid, $o$-hydroxybenzaldehyde, p-hydroxybenzaldehyde; $0.025 \%(\mathrm{w} / \mathrm{v})$ : coumarin.

(q) Miscellaneous nitrogen compounds $(0.1 \%, \mathrm{w} / \mathrm{v})$ : acetamide, benzamide, benzylamine, betaine $\mathrm{HCl}$.

(r) Paraffin hydrocarbons ( $\mathrm{I} \%, \mathrm{w} / \mathrm{v})$ : liquid paraffin.

Organic compounds as sole sources of carbon and nitrogen for growth. The three compounds tested - acetamide, serine and trimethyldiamine - were added to the basal medium described by Tsukamura (1966).

Tolerance to chemical inhibitors, temperature and $p H$. In all these tests the basal medium was YEA. For the inhibition tests various concentrations of sodium azide, sodium chloride, bismuth citrate, crystal violet, phenol, potassium tellurite, phenyl ethanol, Teepol, tetrazolium and thallous acetate were added to the basal medium. The ability of strains to grow at $10^{\circ}, 35^{\circ}, 40^{\circ}, 45^{\circ}$ and $50^{\circ}$, and in media of $\mathrm{pH} 4$ to $\mathrm{pH} 10$, was examined. All these tests were carried out in Replidishes. After 14 days' incubation tests were scored as positive or negative, depending upon the presence of absence of growth. The sensitivity of strains to 5 i.u. of penicillin was examined with antibiotic discs. This test was carried out in plates and read after 7 days.

Biochemical tests. Catalase, oxidase (Steel, I96I) and cytochrome oxidase (Deibel \& Evans, I960) production was examined on I- to 5-day YEA cultures. The medium described by Tacquet (1962) was used to detect the formation of $m$-nitrophenoloxidase and $p$ nitrophenoloxidase. Allantoinase, nitratase and urease activity were detected by means of the media and methods of Gordon (1967), the results being recorded weekly for 4 weeks. Resistance to lysozyme was determined according to the method described by Gordon (I966a). 
Coding of features for computation

Most features existed in one of two mutually exclusive states, and were scored for computation by recording positive reactions as $I$ and negative as o. Pigmentation and colonial characters were divided into 2 to 5 mutually exclusive states; organisms were coded I for the particular character state they exhibited and o for the others. The additive method of Sokal \& Sneath (1963) was used to code multistate quantitative characters, tolerance to chemical inhibitors, $\mathrm{pH}$ and temperature, some of the hydrolysis tests and for the benzidine test. Inapplicable characters, such as the detection of pleomorphism in strains with a permanent mycelium, were designated $\mathrm{IO}_{9}$ (non comparable) and ignored in calculating similarity coefficients. Thirty-seven characters gave either all positive or all negative results and as they had no discriminating value they were not included for computation (Table 2). Each strain was therefore tested for 204 unit characters (Table I). All the results were entered onto standard IBM punch cards.

Table 2. Characters which have no discriminating value

Utilization, as sole carbon source, of:

Sodium alginate
Sodium formate
Sodium fumarate
Sodium oxalate
Pelargonic acid
$o$-Hydroxybenzoic acid
DL-Arginine HCl
DL-Ornithine
D-Tryptophan
Histamine
Putrescine
L-Mandelic acid
Anthranilic acid
Genistic acid
Nicotinic acid
Phthalic acid
Syringic acid
Vanillic acid
Quinic acid
Catechol

$o$-Nitrophenol
$m$-Nitrophenol
$p$-Nitrophenol
Indole-3 acetic acid
Naphthalene
Cinnamic acid
Syringaldehyde
Vanillin
Benzoylformate
Mucic acid
Ferulic acid
$p$-Hydroxybenzaldehyde
Coumarin
Resistance to
I $5 \%$ NaCl
pH 4
Biochemical
Catalase, weak

\section{Computation}

Because of the large amount of data, computation was carried out in two stages. In the first analysis the pathogenic strains, Nocardia asteroides, $N$. brasiliensis, $N$. caviae, $N$. madurae and $N$. pelletieri, were considered, and in the second the soft-growing nocardioform organisms. The overall similarity between strains was calculated in two ways - by the method devised by Sneath (I957) in which negative similarities are excluded, and by the method of Sokal \& Michener (1958) in which negative similarities are included. Thus, where $S$ is the similarity coefficient (usually expressed as a percentage), $n_{s p}$ and $n_{s n}$ the number of positive and negative similarities respectively, and $n_{d}$ the number of non-matching characters, then according to Sneath;

$$
S=n_{s p} /\left(n_{s p}+n_{d}\right)
$$

and according to Sokal and Michener,

$$
S=\left(n_{s p}+n_{s n}\right) /\left(n_{s p}+n_{s n}+n_{d}\right) .
$$

The organisms in each of the four unsorted similarity matrices so obtained were then rearranged into significant groups. Cluster analysis was carried out using two techniques: the 
single linkage method (Sneath, I957) and the unweighted average linkage method (Sokal \& Michener, 1958). All the calculations were carried out on an Elliot computer at Leicester University.

\section{Formation of clusters}

\section{RESULTS AND DISCUSSION}

Eighty-five per cent of 239 test strains could be assigned to one of I 5 clusters. The quantitative taxonomic relationships within and between the clusters are graphically illustrated in the sorted similarity matrices (Fig. I, 2). Dendrograms derived from the matrices, and based on unweighted average linkage cluster analysis, are shown in Fig. 3 to 6 . Nine major and six small minor clusters could be recognized at the $80 \%$ Similarity Level (S-level). For the sake of clarity, and where it was possible, the clusters were given the name most frequently carried by isolates within a cluster. Seven of the major clusters could thus be roughly equated with the species: Nocardia asteroides, $N$. caviae, $N$. brasiliensis, $N$. madurae, $N$. pelletieri, N. turbata and Mycobacterium rhodochrous. There were too few strains in the minor clusters for them to be designated in this way.

Cluster I. The Nocardia asteroides cluster. Taxonomically this was one of the more complex clusters where the 42 strains fell into one of the five subgroups (Table 3). The subgroups were defined at the $85 \%$ S-level or above. Over half the organisms were received as $N$. asteroides, and the others carried specific epithets often considered to be synonyms of this species. Subgroups I A, I B and I C contain strains which shared a high overall similarity. The most homogeneous subgroup comprises the six strains of $N$. farcinica which coalesced above the $90 \% \mathrm{~S}$-level. Included in subgroup I C is strain N34 (ATCC 33 I 8), the type species of the genus. Gordon \& Mihm (1957) considered that the names N. asteroides and N. farcinica referred to a single group, and proposed that the type species $N$. farcinica be accepted as a synonym of $N$. asteroides. In contrast Tsukamura (I969) found two major clusters of $N$. asteroides and redesignated the one which contained the type species $N$. farcinica. The strains $N$. asteroides ( 76 and $\mathrm{N} 79$ ) and $N$. blackwellii (NI22) were included by Tsukamura in the cluster $N$. farcinica. In the present study subgroup I C contains the type species, is distinct from the other subgroups, but includes none of the other common strains found in Tsukamura's $N$. farcinica cluster. Nocardia asteroides $(\mathrm{N} 76)$ is in subgroup I E, the remaining two strains in subgroup I A. Again two strains of $N$. asteroides (N I3 I and N I 40) are found in subgroups I A and I B respectively. Tsukamura (1969) allotted them to a single cluster, $N$. asteroides group Kyoto-I I. He also placed in this cluster $N$. corallina (N84), which was found by me to be a typical strain of Mycobacterium rhodochrous.

Subgroups I D and I E are small and relatively heterogeneous. All the Nocardia paraffinae strains fell into subgroup I D, which also contains the suggested working-type strain of N. asteroides, N317 (Sneath \& Skerman, 1966). Subgroup I E is only marginally included in cluster 1 .

Cluster 2. The Nocardia caviae cluster. Ten strains fell into one or other of the two subgroups (Table 4). Each subgroup is homogeneous and defined at or around the $90 \%$ S-level.

Cluster 3. This cluster contains eight strains (Table 5), is diffuse and, as it stands, of little taxonomic value. A high phenetic similarity is shared, however, by the two strains of Nocardia rhodnii and also by $N$. convoluta (N95) and $N$. pasteuroides. These two minor subgroupings may form nuclei around which additional strains may cluster.

Cluster 5. The Nocardia brasiliensis cluster. Ten strains joined above the $85^{\circ} \circ$ S-level to form a tight homogeneous group (Table 6). This cluster contains the working-type strain of 


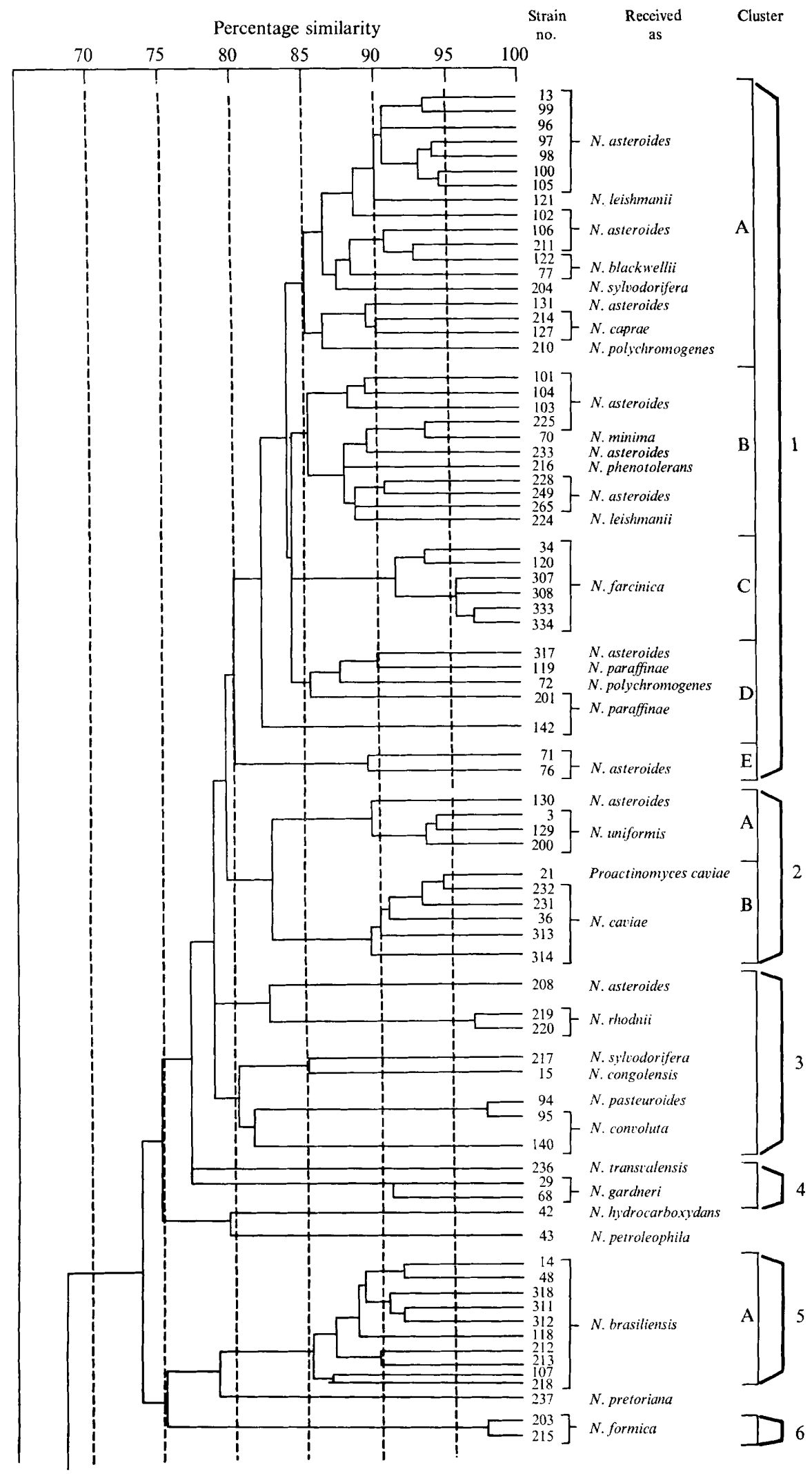

Fig. 3. Dendrogram of the relationships within and between clusters i to 6, negative matches included. 


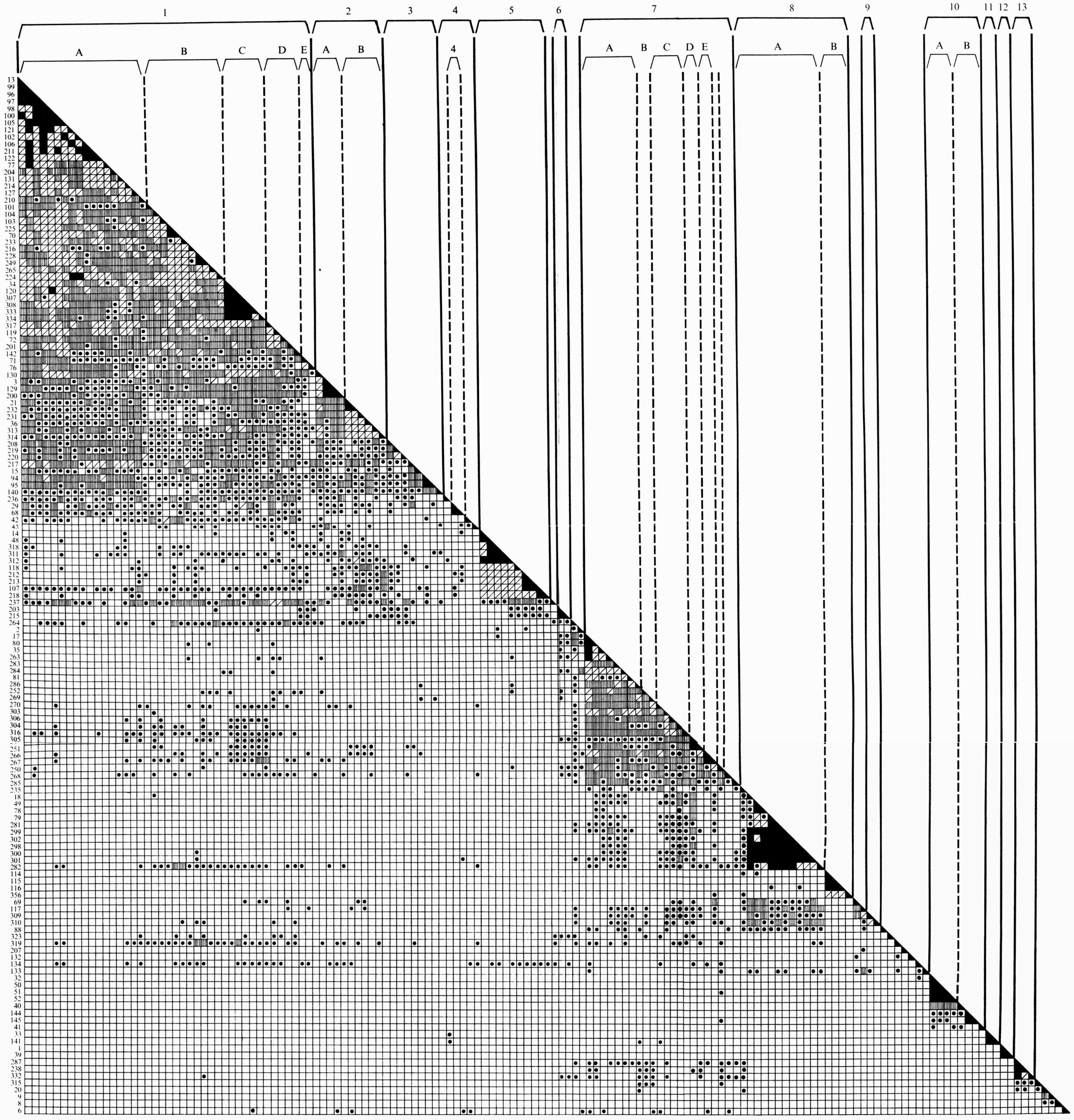

$100-90 \%$

$\square^{9085 \%}$

血 ${ }^{85} 80^{\circ}$.

$80-75 \%$

Fig. I. A sorted similarity matrix of the "hard" growing nocardioform strains. 


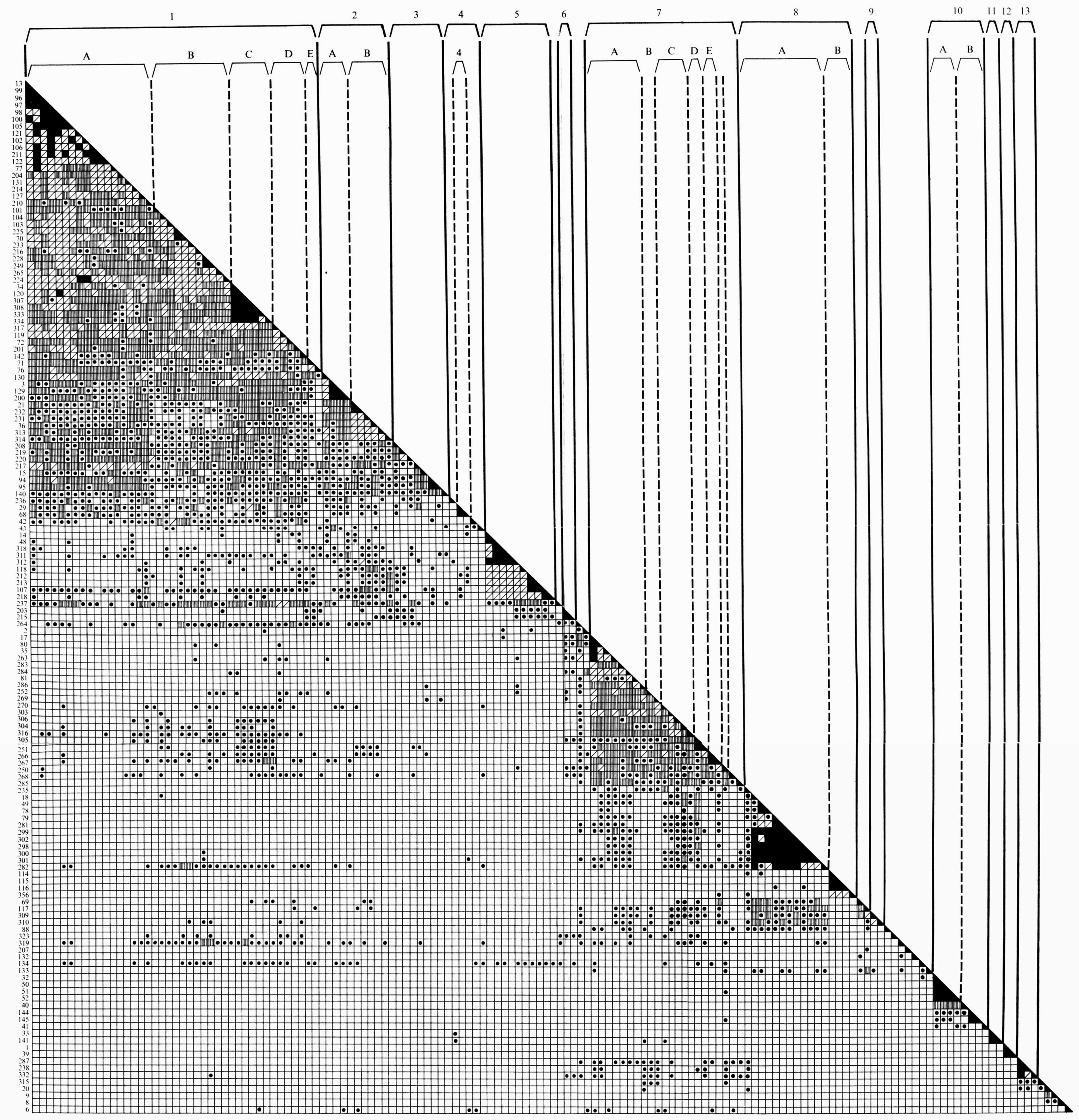

$100-90 \%$

$\square 90.85 \%$

血 ${ }^{85-80 \%}$

80-75\%

Fig. I. A sorted similarity matrix of the "hard" growing nocardioform strains. 


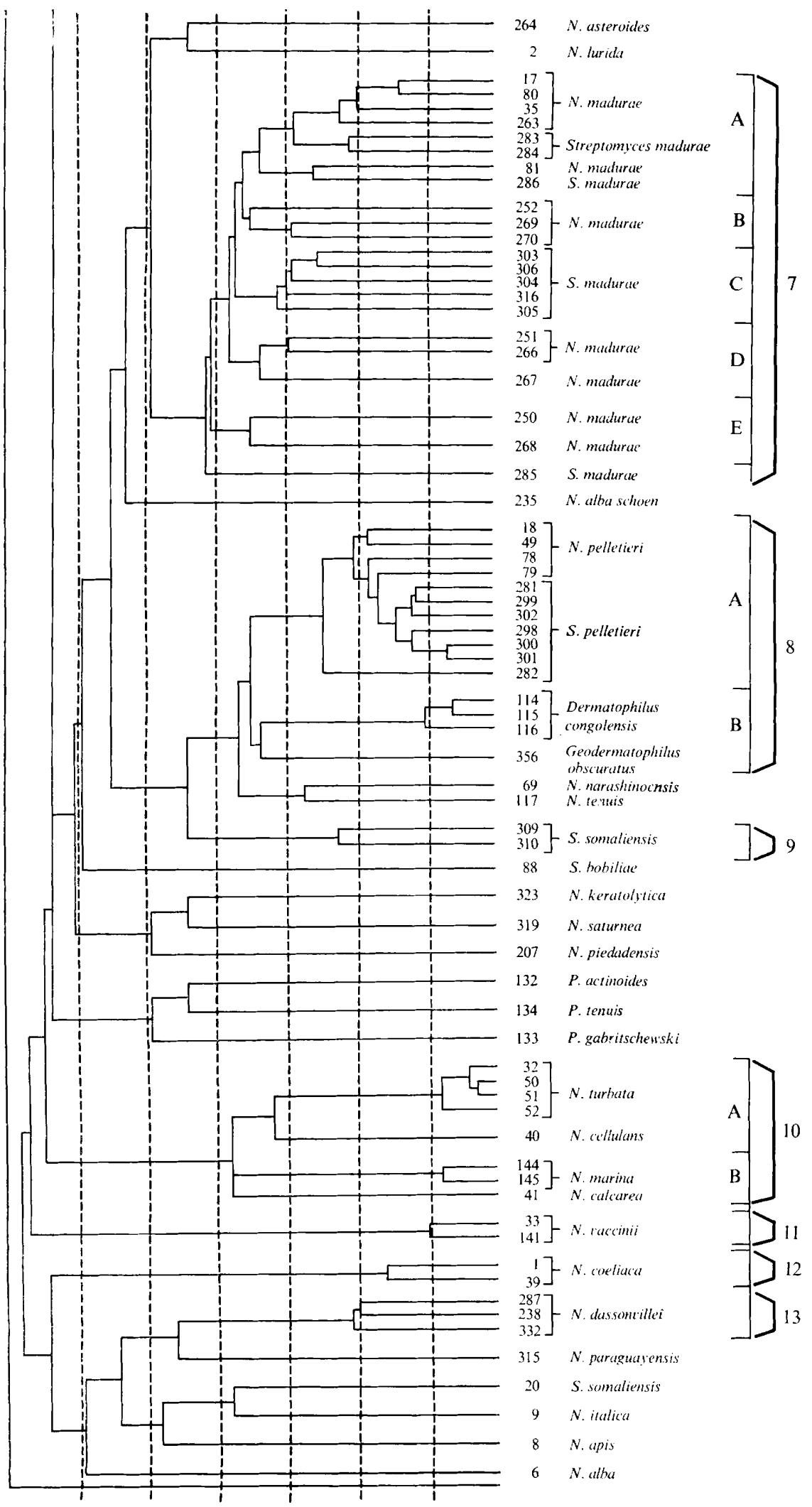

Fig. 4. Dendrogram of the relationships within and between clusters 7 to 13 , negative matches included. 
Percentage similarity

Strain Received Cluster

no. as

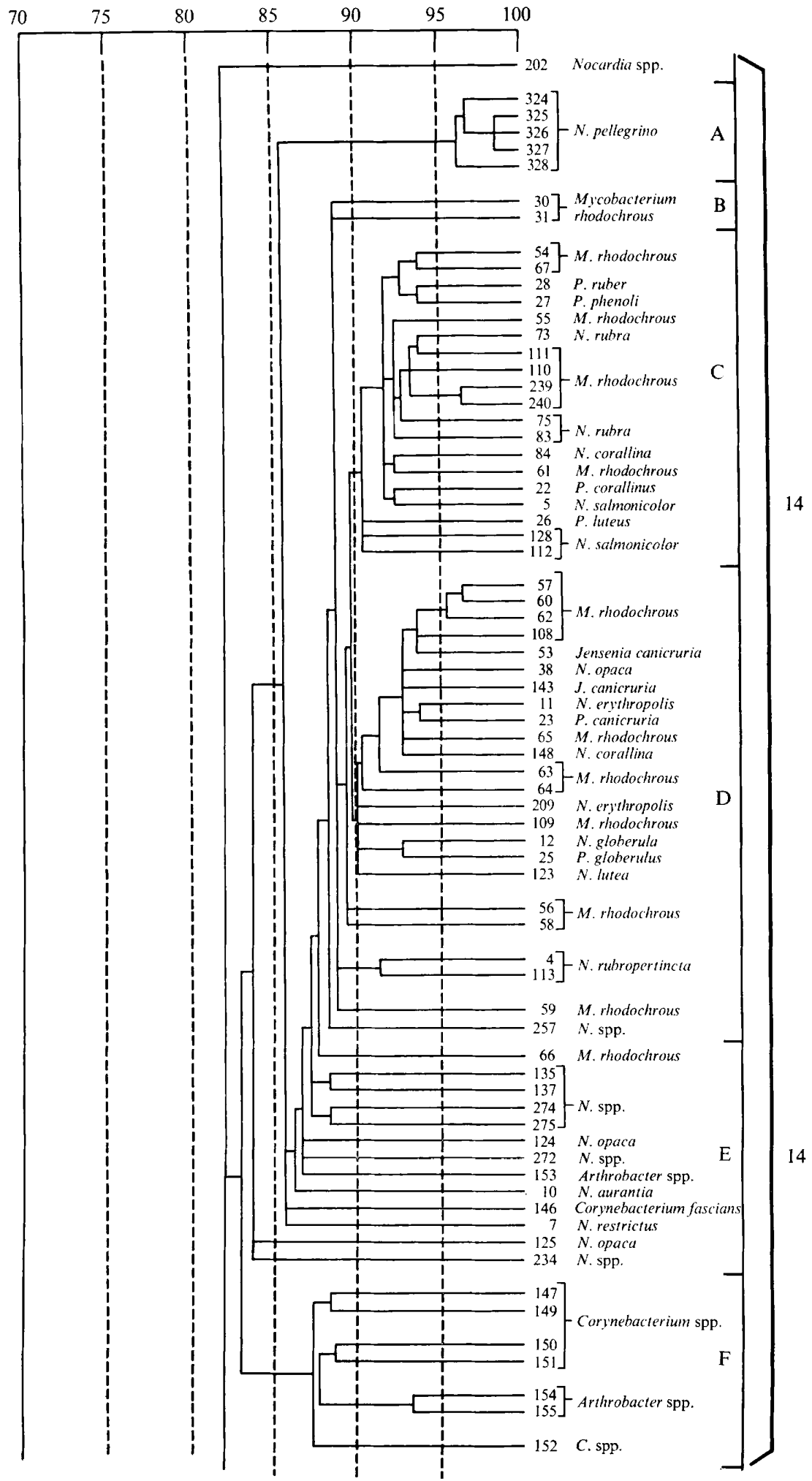

Fig. 5. Dendrogram of the relationships with the $M$. rhodochrous cluster, negative matches included. 


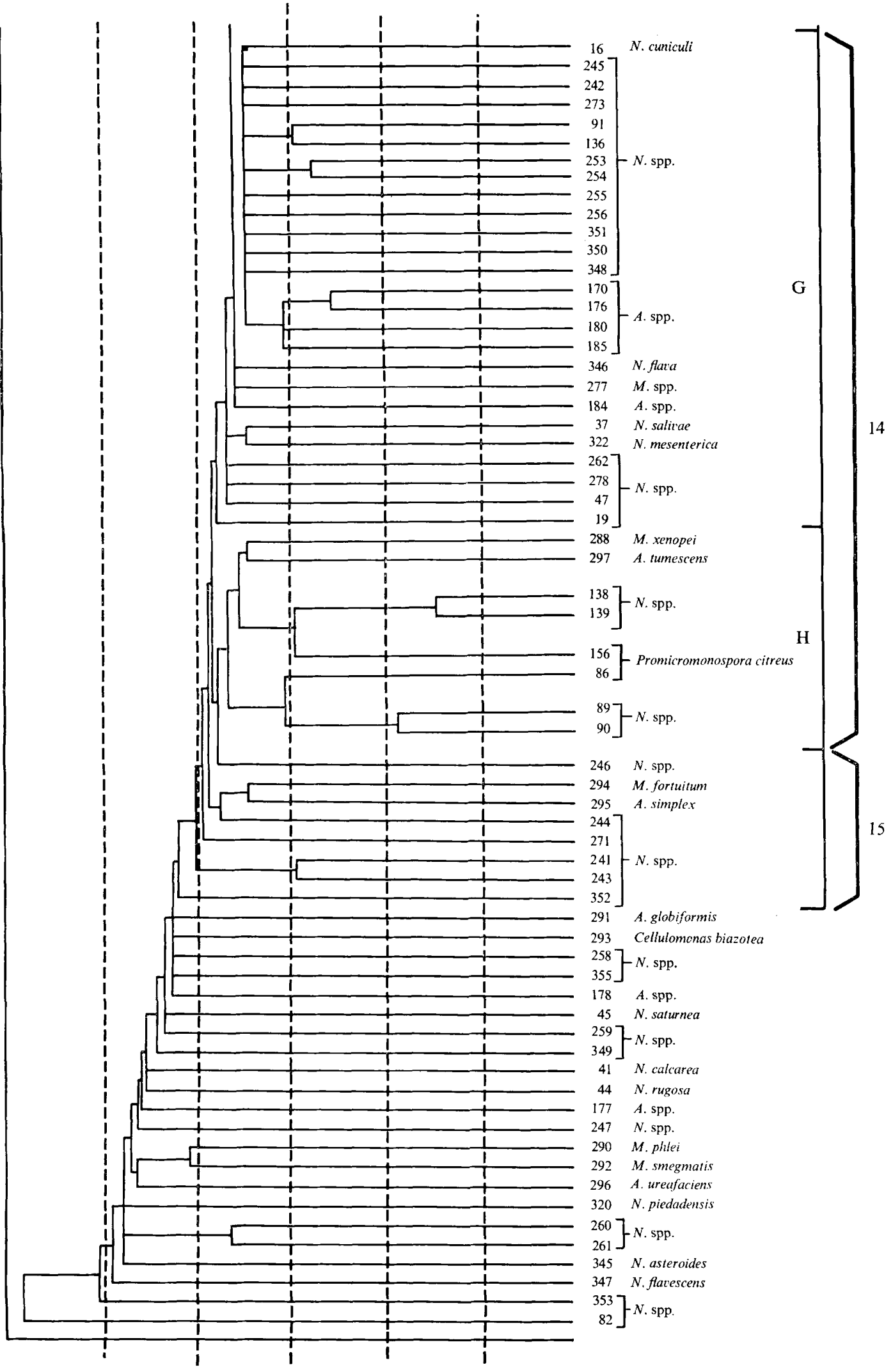

Fig. 6. Dendrogram of the relationships within cluster 15 and between the unplaced strains. 
$N$. brasiliensis and corresponds to the recognizable species bearing that specific name. Nocardia pretoriana $(\mathrm{N} 237)$ is loosely associated with, but not included in, this cluster.

Cluster 7. The Nocardia madurae cluster. Although all 22 strains included in this cluster (Table 7) were received as either $N$. madurae or Streptomyces madurae, the cluster is very diffuse. Thus while the strains were divided into five subgroups, no two strains shared a

\section{Table 3. Strains assigned to cluster I, the Nocardia asteroides group}

\section{Subgroup I A}

$N$. asteroides (Eppinger) Blanchard; NCTC 8595, strain Greece-Salonika; ATCC 14759. Isolated by R. H. Gorrill from pus of empyema (Nocardia sebivorans)

N. asteroides; Dr R. E. Gordon, Rutgers University, New Brunswick, U.S.A., w 3300 ; S. A. Waksman; A. T. Henrici

$N$. asteroides; Dr R. E. Gordon, N659 ( $N$. caprae)

N. asteroides; Dr R. E. Gordon, 6I 8; E. N. Azarowicz, 35; CBS 242.37; Polacci $N$. asteroides; Dr R. E. Gordon, 508; received from P. Thibault as $N$. eppingerii. Isolated from brain abscess

N. asteroides; Dr R. E. Gordon, 652 (N. phenotolerans); E. N. Azarowicz, I I0;

A. Gonzáles Ochoa, II39; A. L. Carrión

N. asteroides; Dr R. E. Gordon, 653; E. N. Azarowicz, I I I A. Gonzáles Ochoa, I028; D. Erikson. Type strain of $N$. rhodnii

N. asteroides; Dr R. E. Gordon, 9969; ATcC9969; C. W. Emmons, 9955; P. Hadley. Isolated from generalized actinomycosis

$N$. asteroides; Dr R. E. Gordon, A9504; ATCC9504. Isolated by O. Felsenfeld from Madura foot

$N$. asteroides var. crateriforme; CBS 242.37 ; Polacci

$N$. asteroides; Dr J. E. Thiemann, Lepetit S.p.A; Milan, Italy, s 545; PSA I 58; ATCC9504; R. E. Gordon, A9504. Isolated by O. Felsenfeld from Madura foot N. blackwellii (Erikson) Waksman \& Henrici; Dr S. T. Williams, Hartley Botanical Laboratories, University of Liverpool, England, E I 5; NCTC630 (Actinomyces blackwellii); J. McFadyean; J. T. Edwards. Isolated from hock joint of foal. ATCC 6846

N. blackwellii; CBS 272.53; ATCC 6846

N. caprae (Silberschmidt) Waksman \& Henrici; CBS 248.33; Institut

Pasteur, Paris

N. caprae; Dr J. E. Thiemann, $\mathbf{5} 469$; PSA 31 ; CBS

N. leishmanii Chalmers \& Christopherson; CBS 333.5I; R. Ciferri, 392

N. polychromogenes (Vallée) Waksman \& Henrici; Dr J. E. Thiemann, A4; PSA 36; CBS

N. sylvodorifera Castellani; ATCC 7372; A. Castellani (Arthrobacter sylvodoriferus). Type strain

\section{Subgroup I B}

$N$. asteroides; Dr R. E. Gordon, w $3410 ; \operatorname{NCTC}(N$. paraffinae)

$N$. asteroides; Dr R. E. Gordon, A8674 (N. minima); ATCC 8674; NCTC 3489;

H. L. Jensen. Type strain of Proactinomyces minimus

$N$. asteroides; Dr R. E. Gordon, W 3409 A ( $N$. polychromogenes); S. A. Waksman

$N$. asteroides; Dr G. L. Bullock, Eastern Fish Disease Lab., Kearneysville, U.S.A., L-IO.4. Isolated from fingerling Rainbow Trout (Salmo gairdneri)

$N$. asteroides; NCMB 1470; D. A. Conroy. Isolated from neon tetras (Hyphessobrycon innesi) with symptoms of piscine tuberculosis

$N$. asteroides; Dr R. Olds, Pathology Department, University of Cambridge, England, $\mathrm{CN} 750$. Isolated from milk of cow

N. asteroides subgroup; Dr T. Cross, University of Bradford, England, CUB I I8; FBA-W 28. Isolated from freshwater of Blelham Tarn

$N$. sp. asteroides type. Dr T. Cross, CUB 415; J. Lacey, A 747. From air sample while opening hay bales in open

N. leishmanii; Dr J. E. Thiemann, A 33; PSA 27; CBS

N. minima (Jensen) Waksman \& Henrici; Institute of Applied Microbiology, University of Tokyo, IAM0374

N. phenotolerans Werkman \& Patrick; Dr J. E. Thiemann, S547; PSA I6I ; IMRU 652; E. N. Azarowicz, I Io; A. Gonzáles Ochoa, I I39; A. L. Carrión (A. phenotolerans) 


\section{Table 3 (cont.)}

\section{Subgroup I C}

\begin{tabular}{|c|c|}
\hline N 34 & N. farcinica Trevisan; NC1C 4524. Cotype (Sneath \& Skerman, 1966) \\
\hline $\mathrm{NI} 20$ & $\begin{array}{l}N \text {. farcinica; CBS } 223.60 \text {; ATCC } 1378 \text { I. Isolated by Dr Mornet, from a case of bovine } \\
\text { farcy in Senegal }\end{array}$ \\
\hline $\begin{array}{c}\text { N307, } \\
308\end{array}$ & $\begin{array}{l}\text { N. farcinica; Professor F. Mariat, Institut Pasteur, Paris, } 738,735 . \text { Isolated from } \\
\text { cases of bovine farcy in Chad }\end{array}$ \\
\hline \multirow[t]{2}{*}{$\begin{array}{c}\text { N333, } \\
334\end{array}$} & $\begin{array}{l}\text { N. farcinica; Professor H. A. Lechevalier, Rutgers University, New Brunswick, } \\
\text { U.S.A. I } 223 \text {, I } 225\end{array}$ \\
\hline & Subgroup I D \\
\hline N317 & $\begin{array}{l}\text { N. asteroides; ATCC } 19247 \text {; R. E. Gordon, } 727 ; \text { L. Ajello, M I 70-6; W. M. Bowman. } \\
\text { Suggested working type (Sneath \& Skerman, 1966) }\end{array}$ \\
\hline NII & $\begin{array}{l}\text { N. paraffinae (Jensen) Waksman \& Henrici; CBS } 255 \cdot 58 \text {; Dr Borghans, Willemstad, } \\
\text { 13482. Isolated from a lesion of an ear }\end{array}$ \\
\hline $\mathrm{N} \mathrm{I} 42$ & N. paraffinae; Department of Agriculture, University of Sydney, 2 I 7 I \\
\hline N 20I & N. paraffinae; CBS 514.67 . Isolated from plaster work \\
\hline $\mathrm{N} 72$ & $\begin{array}{l}\text { N. polychromogenes; International Center for the Distribution of Type Cultures, } \\
\text { Lausanne, Switzerland. LA I610 }\end{array}$ \\
\hline
\end{tabular}

\section{Subgroup I E}

$N$. asteroides; LA I6I3; Institut Pasteur, Paris, 30 I

N. asteroides; Dr S. T. Williams, E 13 ; NCTC676I

\section{Table 4. Strains assigned to cluster 2, the Nocardia caviae group}

\section{Subgroup 2 A}

$\mathrm{NI} 30$

$N$. asteroides; CBS 226.38. Received as $N$. madurae by Pinoy.

N. uniformis Marton \& Szabo; NCIB9631; L. Silvestri

N. uniformis; CBS224.60; I Szabo

N. uniformis; Dr I Szabo, Laboratory of Soil Biology, Sopron, Hungary, I 849

\section{Subgroup 2 B}

Proactinomyces caviae Snijders; CCM I97; J. de Ley

N. caviae (Erikson) Gordon \& Mihm; NCTC 1934; E. P. Snijders; ATCC I4629. Isolated from an infected ear of a guinea pig. Cotype (Sneath \& Skerman, I966)

$N$. caviae; Dr R. Olds, CN 749. Isolated from a dachshund

N. caviae; Dr R. Olds, CN75I. Isolated from a corgi

N. caviae; Professor F. Mariat, 75I, $77 \mathrm{I}$

Table 5. Strains assigned to cluster 3

Nocardia asteroides; Dr J. E. Thiemann, A8; PSA 33; CBS

N. congolensis; NCTC 5I 75

$N$. convoluta Chalmers \& Christopherson; Dr A. Gonzáles Ochoa, Instituto de Salubridad y Enfermedades Tropicales, Mexico I 7, DF 98

N. convoluta; Dr J. Antheunisse, Landbouwhogeschool, Wageningen, Holland; ATCC 4275 ; H. J. Conn (Mycobacterium convolutum); P. H. H. Gray

N. pasteuroides; Dr A. Gonzáles Ochoa, 35

N. rhodnii (Erikson) Waksman \& Henrici; Professor C. da Silva Lacaz, Universidade de São Paulo, Brazil. Isolated from the gut of Rhodnius prolixus N. sylvodorifera Castellani; Dr J. E. Thiemann, s546; PSA I60; ATCC 7372, A. Castellani. Type strain

high phenetic similarity. The suggested working-type strain of the species (Sneath \& Skerman, I966) is found in subgroup $7 \mathrm{~A}$.

Cluster 8. The Nocardia pelletieri cluster. The strains are listed in Table 8 . They fell into two contrasting subgroups linked together just above the $80 \% \mathrm{~S}$-level. With a single 
exception the eleven strains received as either $N$. pelletieri or Streptomyces pelletieri coalesced at or above the $85 \% \mathrm{~S}$-level. The three strains of Dermatophilus congolensis form the centre of the second tight subgroup. The species Geodermatophilus obscuratus is included at the periphery of this subgroup. The association of the subgroups within a single cluster is probably more apparent than real.

Table 6. Strains assigned to cluster 5, the Nocardia brasiliensis group

NI4
N48
NIO7
NII 8
N2I
N2I3
N2I 8
N3I I
N3I
N3I 8

$\mathrm{N}$ I 7

N35

$\mathrm{N} 80$

N8I

N 263

$\mathrm{N} 283$,

284

$\mathrm{N} 286$

$\mathrm{N} 252$

N269,

270

N303

$\mathrm{N} 304$

N 305

N306

N 316

N 25 I

N266, 267

N 250

N 268

N 285

N. brasiliensis (Lindenberg) Pinoy; NCTC 10300; ATCC I9295

N. brasiliensis; Dr R. E. Gordon, 744; A. Gonzáles Ochoa, 409; ATcc9r 295

N. brasiliensis; Dr R. E. Gordon, N239I (Nocardia pretoriana); NCTC 239I

$N$. brasiliensis; CBS 438.64; A. H. Klokke, 300. Isolated from multiple sinus in right knee

$N$. brasiliensis; Dr J. E. Thiemann, s 580; PSA 2 I 3 ; IMRU 774

N. brasiliensis; Dr J. E. Thiemann, s 58I ; PSA 214 ; IMRU 848; J. D. Schneidau, Jun. 386 в; C. da Silva Lacaz, 85

N. brasiliensis; Professor C. da Silva Lacaz

N. brasiliensis; Professor F. Mariat, 768

N. brasiliensis; Professor F. Mariat, 337

N. brasiliensis; ATCC 19296; R. E. Gordon, 845; J. D. Schneidau, Jun., 38I ; A. Batista, 63I; Institut Pasteur, Paris, 337. Uncertain cotype (Sneath \& Skerman, 1966)

Table 7. Strains assigned to cluster 7 , the Nocardia madurae group

Subgroup $7 \mathrm{~A}$

N. madurae (Vincent) Blanchard; NCTC I070. Isolated from a case of Madura foot N. madurae; NCTC 5654; ATCC 19425. Isolated by J. T. Duncan from mycetoma of foot. Suggested working type (Sneath \& Skerman, 1966)

N. madurae; Dr S. T. Williams, E23; R. E. Gordon, 507; P. Thibault

N. madurae; Dr S. T. Williams, E 24; R. E. Gordon, 43I ; I. Christison; N. F. Conant, 2177; A. Gonzáles Ochoa, 4I5

$N$. madurae type; Dr T. Cross, cuB4IO; J. Lacey. Isolated from stored hay

Streptomyces madurae; Professor I. G. Murray, School of Tropical Medicine,

London, II $55 ; 759$

S. madurae; Professor I. G. Murray, 1056

\section{Subgroup 7 B}

N. madurae; Dr T. Cross, CUB I $30 ;$ J. Lacey; M. P. Lechevalier. Isolated from soil $N$. sp. madurae type; Dr T. Cross, CUB436, 437; J. Lacey A47I, A683. Isolated from moist barley grain

\section{Subgroup $7 \mathrm{C}$}

S. madurae; Professor F. Mariat, 364. Isolated from a case of Madura foot

S. madurae; Professor F. Mariat, 391

S. madurae; Professor F. Mariat, 373. From a case of mycetoma, Fort Lamy, Chad

S. madurae; Professor F. Mariat, 767

S. madurae; Professor F. Mariat, 384

\section{Subgroup $7 \mathrm{D}$}

N. madurae subgroup; Dr T. Cross, CuB I23; P. C. K. Austwick, v6973 C

$N$. sp. madurae type; Dr T. Cross, CuB 433-4; J. Lacey, A 151, 322. Isolated from sugar cane bagasse and hay respectively

Subgroup $7 \mathrm{E}$

N. madurae subgroup; Dr T. Cross, cuB I22; P. C. K. Austwick, v673 в (S. fradiae)

N. sp. madurae type; Dr T. Cross, 435; J. Lacey, A 337. Isolated from oat grain

S. madurae; I. G. Murray, 767 
Table 8. Strains assigned to cluster 8 , the Nocardia pelletieri group

Subgroup $8 \mathrm{~A}$

$N 18$
$N 49$
$N 78$
$N 79$
$N 281$,
282
N298,
299
N300,
302

$N 114$ to
I 6
N356

N. pelletieri (Laveran) Pinoy; NCTC J0000

N. pelletieri; Dr R. E. Gordon, 513; P. Thibault

N. pelletieri; Dr S. T. Williams, E21; R. E. Gordon, 408; J. M. Coffey, 47293

N. pelletieri; Dr S. T. Williams, E 22; R. E. Gordon, 610; E. N. Azarowicz, 10

Streptomyces pelletieri; Professor I. G. Murray, 1065, 1067

S. pelletieri; Professor F. Mariat, 726, 381

S. pelletieri; Professor F. Mariat, 385, 394, 729

Subgroup 8 B

Dermatophilus congolensis van Saceghem; Professor V. B. D. Skerman, University of Queensland, Australia, 530-2

Geodermatophilus obscuratus Luedemann; Dr G. M. Luedemann, Schering

Corporation, Bloomfield, New Jersey, D 20. Isolated from soil

Table 9. Strains assigned to cluster 10, the Nocardia turbata group

Subgroup io A

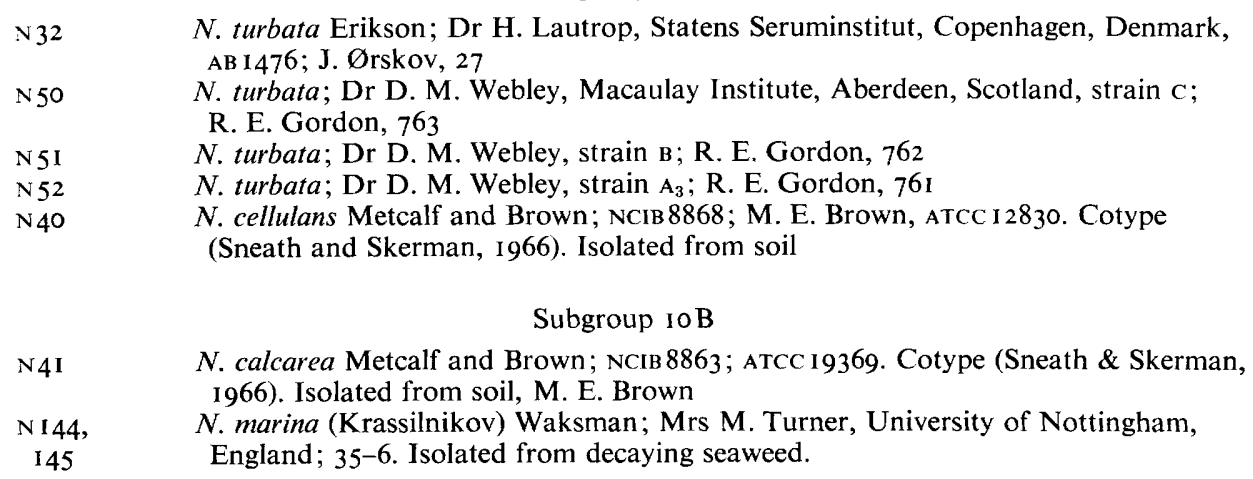

Cluster 10. The Nocardia turbata cluster. The strains in this cluster fell into two distinct and contrasting subgroups (Table 9). The four $N$. turbata strains unite above the $95 \% \mathrm{~S}$-level to form a tight centre to subgroup ro A. The type strain of $N$. cellulans is found at the periphery of this subgroup. Two strains of $N$. marina and the type strain of $N$. calcarea form the second fragmented subgroup.

Cluster 14. The Mycobacterium rhodochrous cluster. The 104 organisms in this cluster are assigned to subgroups (Table ro).

Homogeneous subgroups. Four of the subgroups contain strains which share a relatively high overall similarity. Subgroup I $4 \mathrm{~A}$ is formed by Nocardia pellegrino strains fused together above the $95 \%$ S-level. Two strains of Mycobacterium rhodochrous uniting just below the $90 \%$ S-level make the second subgroup. Strains bearing this name are also found in three of the other subgroups. Subgroup I4C contains I 9 strains linked above the $90 \% \mathrm{~S}$-level. It contains eight $M$. rhodochrous strains and organisms carrying seven specific epithets attached to either Nocardia or Proactinomyces. Twenty-four strains are assigned to the largest subgroup, ${ }_{14} \mathrm{D}$, also delineated above the $90 \% \mathrm{~S}$-level. Almost half were received as $M$. rhodochrous, the additional ones as eight species attributed to the genus Jensenia, Nocardia or Proactinomyces. 
Table Io. Strains assigned to cluster I4, the Mycobacterium rhodochrous group

Subgroup I4A

N324

N325 to

8

N30

N3I

N54

N 55

N6I

N67

NIIO

N II I

N239

$\mathrm{N} 240$

$\mathrm{N} 84$

N 73

N 75

N83

N 5

N II 2

N 128

$\mathrm{N} 22$

N26

$\mathrm{N} 27$

N 28

Nocardia pellegrino Pellegrino; ATCC 1 5998; G. Castelnuova; Institut Pasteur; L. Pellegrino

N. pellegrino; Professor G. Castelnuova, Instituto Superiore Di Sanita, Rome, 906 B, 107, 906, 350

\section{Subgroup I4B}

Mycobacterium rhodochrous (Zopf) Gordon \& Mihm; Dr R. E. Gordon, A I 2974 (Corynebacterium fascians); ATCC I2974; W. H. Burkholder, CF I7; P. E. Tilford

M. rhodochrous; Dr R. E. Gordon, W 2 I (Micrococcus rhodochrous); S. A.

Waksman; R. S. Breed

\section{Subgroup $14 \mathrm{C}$}

M. rhodochrous; ATCC13808; R. E. Gordon, 372 (Rhodococcus rhodochrous); R. S. Breed; Král collection

M. rhodochrous; Dr R. E. Gordon, 8I 7 (Mycobacterium sp.); N. M. McClung, B I6I A

$M$. rhodochrous; Dr R. E. Gordon, w 3408 (N. corallina); S. A. Waksman; ATCC 4273; H. J. Conn; P. H. H. Gray, O-3

M. rhodochrous; NCTC 10210

M. rhodochrous; Dr R. E. Gordon, w 3639 (N. rubra); S. A. Waksman; G. Giolitti

M. rhodochrous; Dr R. E. Gordon, 562 (Proactinomyces ruber); N. M. McClung; CBS

M. rhodochrous; NCTC 8727

$M$. rhodochrous; NCTC $857 \mathrm{I}$

N. corallina; (Bergey et al.) Waksman \& Henrici; Dr S. T. Williams, E4I ; CBS $197.57 ;$ ATCC 4273

N. rubra (Kruse) Chalmers \& Christopherson; Dr S. T. Williams, E 40; CBS

N. rubra; LA I 609

N. rubra; Dr S. T. Williams, E 40; CBS

N. salmonicolor (den Dooren de Jong) Waksman \& Henrici; NCIB970I

N. salmonicolor; Professor V. B. D. Skerman, I 2 I

N. salmonicolor; CBS I96.57

P. corallinus (Hefferan) Jensen; Dr M. Kocur, J. E. Purkyně University, Brno, CCM 3245, ATCC 4273 (N. corallina)

$P$. luteus Christopherson \& Archibald; CCM I98; J. de Ley

$P$. phenoli; M. Kocur, BS 278; NCIB9I60

$P$. ruber Krassilnikov; CCM 269

\section{Subgroup I4D}

Jensenia canicruria Bisset \& Moore; NCIB 8I 47; ATCC I 1048. Type strain

J. canicruria; Mrs M. Turner, 29. Type strain

M. rhodochrous; Dr R. E. Gordon, I 256 (N. restrictus); A. I. Laskin, 29I4. Isolated from soil

M. rhodochrous; Dr R. E. Gordon, I293s (Arthrobacter)

$M$. rhodochrous; Dr R. E. Gordon, 1257 (N. restrictus); A. I. Laskin; E. R. Squibb and Sons, 2915. Isolated from soil

M. rhodochrous; Dr R. E. Gordon, I240 (Corynebacterium rubrum); A. J. Crowle

M. rhodochrous; Dr R. E. Gordon, I 293 R (Arthrobacter sp.)

$M$. rhodochrous; Dr R. E. Gordon, 768 (P. opacus), D. M. Webley, T 14

$M$. rhodochrous; Dr R. E. Gordon, 463 (Mycobacterium sp.); T. C. Stadtman

$M$. rhodochrous; Dr R. E. Gordon, 417 (N. globerula); W. C. Haynes, B-I 306; ATCC 9356

$M$. rhodochrous; Dr R. E. Gordon, A 7698 (C. equi); ATCC 7698; H. W. Schoening

$M$. rhodochrous; Dr R. E. Gordon, A 4277 (N. erythropolis); ATCC4277; H. J.

Conn; P. H. H. Gray, 0-5. Type strain

M. rhodochrous; Dr R. E. Gordon, 494 (P. globerulus); P. H. H. Gray, M47

$N$. corallina; Mrs M. Turner, 83. Isolated from soil

N. erythropolis (Gray \& Thornton) Waksman \& Henrici; NCIB9158; M. Kocur,

BS 277 ( $P$. erythropolis). Cotype (Sneath \& Skerman, I966)

$N$. erythropolis; Dr J. E. Thiemann, A 2 ; PSA 68; CBS 
Table Io (cont.)

N. globerula (Gray) Waksman and Henrici; NCIB9159; M. Kocur, BS 279 ( $P$. globerulus); ATCC 19370. Cotype (Sneath \& Skerman, 1966) $N$. lutea Christopherson \& Archibald; CBS 334.5I; R. Ciferri, 373

N. opaca (den Dooren de Jong) Waksman \& Henrici; NCIB9409; D. M. Webley, strain T 16

N. rubropertincta (Hefferan) Waksman and Henrici; NCIB9664

N. rubropertincta; Professor V. B. D. Skerman, I34

Nocardia spp., Dr T. Cross, CUB 197. Isolated from Blelham Tarn

P. canicruria Jensen; CCM 277 ; P. H. H. Gray; ATCC 4277

P. globerulus Reed; Ссм 279; P. H. H. Gray

\section{Subgroup I $4 \mathbf{E}$}

$N$. restrictus Turfitt; NCIB 10027

N. aurantia; NCIB 9557; ATCC I 2674

$M$. rhodochrous; NCTC 8I 39

N. opaca; CBS 330.61, 331.61. Isolated by Dooren de Jong, 279, 292. Type strains

'Nocardia sp.' Dr J. Antheunisse, AC 338. Isolated from rhizosphere of grass

'Nocardia sp.' Dr J. Antheunisse, AC 339. Isolated from rhizosphere of grass

'Arthrobacter sp.' Mrs M. Turner, x 45. Isolated from seaweed

C. fascians (Tilford) Downson; Mrs M. Turner, 39

Nocardia sp.; Professor H. Veldkamp, University of Groningen, Holland, $4 \mathrm{X}$

Nocardia sp.; Dr P. Latter, Merlewood Research Station, Grange-over-Sands, England. I9/7 56/4. Isolated from Juncus sp. litter

Nocardia sp.; Dr P. Latter, 30/7 34/2; $\frac{3}{8} 36 /$ I 3. Isolated from soil on Signy Island

\section{Subgroup $14 \mathrm{~F}$}

'coryneform'; Mrs M. Turner, 65, 93. Isolated from soil

'coryneform'; Mrs M. Turner x I0, x 18, x 34 . Isolated from seaweed

'arthrobacter'; Mrs M. Turner, x 55-6. Isolated from seaweed

\section{Subgroup ${ }_{14} \mathrm{G}$}

N. cuniculi Snijders; NCTC 1935 (A. sumatrae)

N. flava (Krassilnikov) Waksman and Henrici; CBS, strain Vruggink Nocardia sp.; NCTC 7915

N. salivae Davis \& Freer; NCTC 10207. Holotype (Sneath \& Skerman, I966)

Nocardia sp.; Dr M. Goodfellow. Isolated from soil

Nocardia sp.; Professor H. Veldkamp, A 86. Isolated from soil

'Nocardia sp.'; Dr J. Antheunisse, AC 86 . Isolated from peaty soil

'arthrobacter'; Dr J. Went, ITBON, I I, Kemperbergerweg, Arnhem, Holland, I 80, I 845 . Isolated from acid forest soil

'arthrobacter'; Dr J. Went, 1 I 5, 88 $b_{2}, 338$. Isolated from alkaline forest soil

Nocardia sp.; Dr I. S. Bowie, Department of Microbiology, University of Otago, New Zealand, B 32, B 48. Isolated from soil

Nocardia sp.; Dr T. Cross, 193-6. Isolated from Blelham Tarn

Nocardia sp.; Dr T. Cross, сuв 364, J. Lacey, A 64I. Isolated from hay

Nocardia sp.; Dr P. Latter, 30/7, I 2. I I. Isolated from peat

Mycobacterium sp.; CBS, Myc. 50. Human source

Nocardia sp.; cBs, Carleton. Isolated from Anthoceros sp.

' $N$. mesenterica' (Orla-Jensen) Waksman \& Henrici; cBS

Nocardia sp.; Dr T. Watson, Hartley Botanical Laboratories, University of

Liverpool, England. Isolated from seawater

Nocardia sp.; Dr T. Watson. Isolated from sand dune soil 


\section{Table Io (cont.)}

\section{Subgroup $14 \mathrm{H}$}

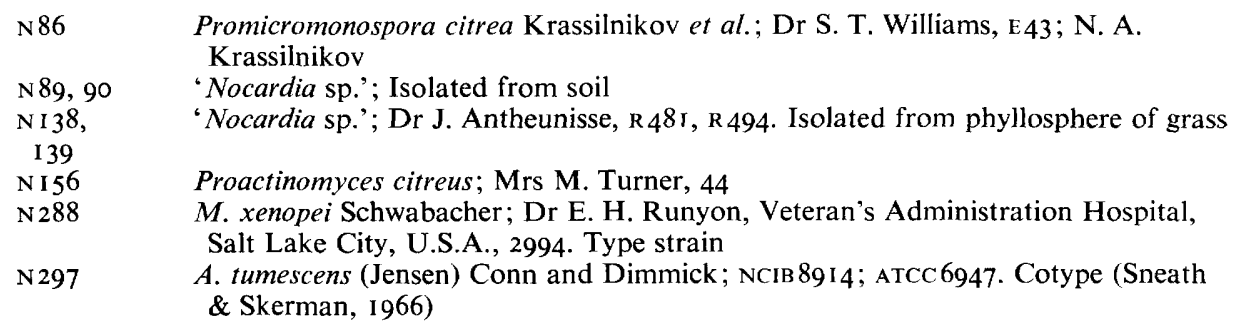

Table I I. Strains assigned to cluster 15

$\begin{array}{ll}\text { N24I } & \text { Nocardia sp.; Dr I. S. Bowie, B I4. Isolated from soil } \\ \text { N 243, } & \text { Nocardia sp.; Dr I. S. Bowie, B 40-I, B 3I. Isolated from soil } \\ \text { 244, 246 } & \\ \text { N 27I } & \text { Nocardia } \text { sp.; Dr P. Latter 4/2 33/I4. Isolated from Juncus sp. litter } \\ \text { N294 } & \text { Mycobacterium fortuitum Cruz; ATCC 684I ; Cruz. Cotype (Sneath \& Skerman, 1966) } \\ \text { N295 } & \text { Arthrobacter simplex (Jensen) Lochhead; NCIB 8929; ATCC 6946. Cotype (Sneath \& } \\ & \text { Skerman, I966) } \\ \text { N352 } & \text { Nocardia } \text { sp.; Dr T. Watson, B 19. Isolated from sea water }\end{array}$

Table I2. Strains assigned to the minor clusters

Cluster 4

\begin{tabular}{|c|c|}
\hline $\begin{array}{l}\text { N29 } \\
\text { N68 }\end{array}$ & $\begin{array}{l}\begin{array}{l}\text { Nocardia gardneri (Waksman) Waksman \& Henrici; IFO3385; ATCC } 9604 \\
\begin{array}{l}\text { N. gardneri; IAM0I05 } \\
\text { Cluster } 6\end{array}\end{array}\end{array}$ \\
\hline $\mathrm{N} 203$ & N. formica Harris \& Woodruff; ATCC I 48 I I ; NRRL 2470 \\
\hline N2I5 & N. formica; Dr J. E. Thiemann, s 542 ; PSA I 55 ; M. A. Merck, I 43 \\
\hline & Cluster 9 \\
\hline $\begin{array}{c}\text { N309 to } \\
310\end{array}$ & $\begin{array}{l}\text { Streptomyces somaliensis (Brumpt) Waksman \& Henrici; Professor F. Mariat, } \\
383,386 \\
\text { Cluster I I }\end{array}$ \\
\hline $\mathrm{N} 33$ & $\begin{array}{l}\text { N. vaccinii Demaree \& Smith; National Collection of Plant Pathogenic Bacteria, } \\
\text { Harpenden, England, NCPPB954; ATCC I I092. Holotype (Sneath \& Skerman, 1966) }\end{array}$ \\
\hline $\mathrm{N} I 41$ & $\begin{array}{l}\text { N. vaccinii; Dr J. Antheunisse; ATCC I I092; N. R. Smith, BG 19. Holotype (Sneath } \\
\text { \& Skerman, I 966). Stem galls on Vaccinium }\end{array}$ \\
\hline & Cluster 12 \\
\hline $\begin{array}{l}\text { NI } \\
\text { N39 }\end{array}$ & $\begin{array}{l}\text { N. coeliaca (Gray \& Thornton) Waksman \& Henrici; NCIB } 9574 ; \text { R. W. Traxler } \\
\text { N. coeliaca; NCIB 8939; M. Lumb; ATCC I 3I 8I. Holotype (Sneath \& Skerman, I966) }\end{array}$ \\
\hline & Cluster 13 \\
\hline $\mathrm{N} 238$ & $\begin{array}{l}\text { N. dassonvillei (Brocq-Rousseu) Liégard and Landrieu; NCTC I0489; R. E. Gordon, } \\
\text { I250; D. Taplin; ATCC } 232 \text { I9. Isolated from a case of erosive plantar disease }\end{array}$ \\
\hline $\mathrm{N} 287$ & N. dassonvillei; NCTC 10488; R. E. Gordon, 509; P. Thibault \\
\hline N332 & N. dassonvillei; Professor H. A. Lechevalier, C-CF \\
\hline
\end{tabular}

Heterogeneous subgroups. The four remaining subgroups were relatively heterogeneous. The named strains in subgroup $\mathrm{I}_{4} \mathrm{E}$ are Corynebacterium fascians, Nocardia aurantia, $N$. opaca, $N$. restrictus and a single strain of Mycobacterium rhodochrous. Additional strains, isolated from soil, were received as Nocardia spp. Subgroup $\mathrm{I}_{4} \mathrm{~F}$ contains soil isolates received as corynebacteria or arthrobacters. Subgroup I4G, defined just above the $80 \%$ 
$\mathrm{S}-$ level, is a large diffuse group. It also contains soil isolates and named strains received as $N$. cuniculi, $N$. flava, $N$. mesenterica and $N$. salivae. The final subgroup, $14 \mathrm{H}$, comprises eight strains loosely associated together. They include two strains of Promicromonospora citreus, and the marker strains Arthrobacter tumescens and Mycobacterium xenopei. The heterogeneous subgroups, as they stand, are of little taxonomic value.

Cluster I 5. This cluster is very diffuse and contains a diverse assemblage of organisms (Table I I). Included are the type strains of Arthrobacter simplex and Mycobacterium fortuitum, and organisms labelled Nocardia spp.

Clusters 4, 6, 9, II, I2 and I3. The minor clusters. Thirteen strains fall into one or other of the six minor clusters (Table I2). Little can be said about clusters which contain so few strains. They are, however, clearly separated from one another and from the established major clusters. The strains found in these clusters may therefore be foci around which future distinct clusters may form. Additional strains of Nocardia coeliaca, $N$. dassonvillei, $N$. gardneri, $N$. vaccinii and Streptomyces somaliensis will be studied when available.

The ungrouped strains. The 44 strains listed in Table I 3 cannot be placed into clusters defined at the $80 \%$ S-level. They include the type strains of Nocardia hydrocarboxydans, $N$. italica, $N$. lurida, $N$. petroleophila, $N$. piedadensis and $N$. saturnea, as well as strains named $N$. alba, $N$. apis, $N$. asteroides, $N$. flavescens, $N$. rugosa and $N$. tenuis. Some of these strains were undoubtably misidentified. Most of the marker strains of the genera Arthrobacter, Cellulomonas and Mycobacterium are also unplaced.

\section{Comparison of data using different similarity coefficients and cluster-analysis techniques}

The similarity coefficients considered so far included negative matches, and clustering was based on the unweighted average linkage cluster-analysis technique. Many of the strains, particularly Nocardia asteroides, $N$. madurae and $N$. pelletieri, gave negative responses to many of the tests. There is a danger that when similarity coefficients are based upon the matching coefficient, strains may be clustered together on negative correlations. The data were therefore re-examined and only positive matches scored. The data obtained from each of the two coefficients of association were analysed by single and unweighted average linkage cluster analysis. The matrices and dendrograms produced are large and too complicated to present here. They are available for consultation from the author.

It was found that both of the cluster-analysis techniques gave very similar results. When only positive matches were counted, however, 18 clusters were formed. They are delineated at the $75 \%$ S-level. The discrepancies between the results can be explained.

In the analysis using only positive matches, cluster 3 is not recovered. The two strains of Nocardia rhodnii, and the strain of $N$. convoluta and $N$. pasteuroides, respectively form two distinct minor clusters. The other strains which were included in cluster 3 are now unplaced. Subgroup 8A, which contained $N$. pelletieri strains, and subgroup $8 \mathrm{~B}$, composed of Dermatophilus and Geodermatophilus, are also recovered as distinct clusters in the second analysis. In the same way the subgroups of cluster io are recovered as two separate clusters. Finally several of the strains originally allocated to cluster 15 are unplaced. It would appear that, as anticipated, some of the high overall similarities found within clusters in the first analysis are based upon negative correlations. The original clusters 3 and I 5 are not taxonomically valuable and will not be considered further. In contrast subgroup $8 \mathrm{~A}$, containing $N$. pelletieri, and subgroup Io A, composed of $N$. turbata and $N$. cellulans, will be treated as major clusters. The two smaller subgroups, containing $N$. marina and Dermatophilus congolensis strains respectively, will be considered as minor clusters.

Most of the remaining subgroups defined by the matching coefficient were recovered 
Table 13. Strains which could not be assigned to any of the clusters

\begin{tabular}{|c|c|}
\hline N 291 & $\begin{array}{l}\text { Arthrobacter globiformis (Conn) Conn \& Dimmick; NCIB 8602; ATCC 4336. Cotype } \\
\text { (Sneath \& Skerman, I966) }\end{array}$ \\
\hline N 296 & $\begin{array}{l}\text { A. ureafaciens (Krebs \& Eggleston) Clark; NCIB 781 I ; NCTC 781 I ; ATCC 7562. Holo- } \\
\text { type (Sneath \& Skerman, 1966) }\end{array}$ \\
\hline $\begin{array}{l}\text { N } 177 \\
\quad 178\end{array}$ & 'Arthrobacter sp.'; Dr J. Went. From alkaline forest soil \\
\hline N 293 & $\begin{array}{l}\text { Cellulomonas biazotea (Kellerman et al.) Bergey et al., NCIB 8077; ATCC 486; } \\
\text { N. R. Smith, I } 27 . \text { Cotype (Sneath \& Skerman, 1966) }\end{array}$ \\
\hline N 290 & $\begin{array}{l}\text { Mycobacterium phlei Lehmann \& Neumann; NCTC 8I 5I ; G. Penso; ATCC } 19249 . \\
\text { Suggested working type (Sneath \& Skerman, I966) }\end{array}$ \\
\hline $\mathrm{N} 292$ & $\begin{array}{l}\text { M. smegmatis (Trevisan) Lehmann \& Neumann; NCTC 81 59; R. E. Gordon; W. } \\
\text { Hagan; Alvarez and Tavel. Cotype (Sneath \& Skerman, 1966) }\end{array}$ \\
\hline N6 & $\begin{array}{l}\text { Nocardia alba (Rossi-Doria) Chalmers \& Christopherson; NCIB 9702; K. } \\
\text { Wuhrmann }\end{array}$ \\
\hline N 235 & $\begin{array}{l}\text { N. alba Schoen; Dr I. Uesaka, Kyoto University, Kyoto, Japan, I I3; N. M. } \\
\text { McClung, I I 3; R. E. Gordon, } 506\end{array}$ \\
\hline N8 & N. apis; NCIB $9378 ;$ A. di Marco. Isolated from the intestine of Apis mellifera \\
\hline N 264 & N. sp. asteroides type; Dr T. Cross, CuB $412 ; \mathrm{J}$. Lacey, A 642. Isolated from straw \\
\hline N 345 & N. asteroides; Public Health Laboratories, Leicester, England \\
\hline N 347 & N. flavescens (Jensen) Waksman \& Henrici; CBS, strain Hoffman-La Roche \\
\hline $\mathrm{N} 42$ & N. hydrocarboxydans Nolof \& Hirsch; NCIB9436, strain Hirsch 70. ATCC I 5104 \\
\hline N9 & N. italica Spalla, Amici, Bianchi; NCIB 9386 \\
\hline N323 & N. keratolytica (Acton \& McGuire) Reiss \& Briggs; ATCC 12484 \\
\hline $\mathrm{N} 2$ & N. lurida; NCIB $960 \mathrm{r}$ \\
\hline N69 & N. narashinoensis Endo; IAMOI I 3 \\
\hline N31 5 & $\begin{array}{l}\text { N. paraguayensis Almeida; Professor F. Mariat, 355; IHM95I (Actinomyces } \\
\text { paraguayensis) }\end{array}$ \\
\hline $\mathrm{N} 43$ & $\begin{array}{l}N . \text { petroleophila Hirsch \& Engel; NCIB 9438, strain Hirsch; ATCC I 5777. Type } \\
\text { strain. From soil }\end{array}$ \\
\hline N 207 & $\begin{array}{l}\text { N. piedadensis Castellani; ATCC 15747; A. Castellani. Type strain. Probable cause } \\
\text { of Macroulcus perstans }\end{array}$ \\
\hline N320 & $\begin{array}{l}\text { N, piedadensis; Professor A. Castellani, Institute of Tropical Medicine, Lisbon, } \\
\text { Portugal }\end{array}$ \\
\hline N 237 & $\begin{array}{l}\text { N. pretoriana Pijper \& Pullinger; Dr I. Uesaka, 194; N. M. McClung; J. D. } \\
\text { Schneidau, Jun.; } 368 \text {. Isolated from mycetoma of chest }\end{array}$ \\
\hline N44 & N. rugosa A. di Marco; NCIB 8926 \\
\hline N45 & $\begin{array}{l}N . \text { saturnea Hirsch; NCIB } 9437 \text {, strain Hirsch } 71 \text {; ATCC I } 5809 . \text { Type strain. Isolated } \\
\text { as an air contaminant }\end{array}$ \\
\hline N319 & N. saturnea; ATCC I5778; P. Hirsch, 99. Type strain. Isolated from compost soil \\
\hline N II 7 & N. tenuis Castellani; CBS 260.35 \\
\hline N 236 & $\begin{array}{l}\text { N. transvalensis Pijper and Pullinger; Dr I. Uesaka, I93; N. M. McClung, 193; } \\
\text { J. D. Schneidau, Jun.; } 2392 ; \text { R. E. Gordon, 2392. Isolated from mycetoma of foot }\end{array}$ \\
\hline N 82 & Nocardia sp.; Dr S. T. Williams, E 32 \\
\hline $\mathrm{N} 202$ & Nocardia sp.; Leicester PHLs. Isolated from sputum \\
\hline $\mathrm{N} 258$ & $\begin{array}{l}\text { Nocardia sp.; Dr T. Cross, CUB } 353 ; \text { J. Lacey, A } 32 \text { I. Isolated from moist barley } \\
\text { grain }\end{array}$ \\
\hline $\mathrm{N} 247$ & Nocardia sp.; Dr I. S. Bowie, B42. From soil \\
\hline $\mathbf{N} 259$ & Nocardia sp.; Dr T. Cross, CUB $355 ;$ J. Lacey, A 333 . Isolated from hay \\
\hline $\begin{array}{l}\mathrm{N} 260 \\
261\end{array}$ & $\begin{array}{l}\text { Nocardia sp.; Dr T. Cross, CuB } 359,360 ; \mathrm{J} . \text { Lacey, A 409, A4Io. Isolated from } \\
\text { moist barley grain }\end{array}$ \\
\hline $\begin{array}{l}\text { N } 349, \\
353,355\end{array}$ & Nocardia sp.; Dr T. Watson, A 27, в 24, в 100. Isolated from beach sandy soil \\
\hline N 132 & $\begin{array}{l}\text { Proactinomyces actinoides (Smith) Krassilnikov; Professor V. D. Kuznetsov, } \\
\text { U.S.S.R. Research Institute for Antibiotics, Moscow, RIA } 644\end{array}$ \\
\hline N I 33 & P. gabritschewski (Berestnev) Krassilnikov; Professor V. D. Kuznetsov, RIA 642. \\
\hline N 134 & P. tenuis (Castellani) Krassilnikov; Professor V. D. Kuznetsov; RIA638 \\
\hline N 88 & $\begin{array}{l}\text { Streptomyces bobiliae (Waksman and Curtis) Waksman \& Henrici; Dr S. T. } \\
\text { Williams, A } 34\end{array}$ \\
\hline $\mathrm{v} 20$ & S. somaliensis; \\
\hline
\end{tabular}


when only positive matches were scored. They include the subgroups of cluster 2 , as well as four of the five subgroups of the Nocardia asteroides cluster. The single exception, subgroup I D, is placed at the periphery of subgroup I $A$ in the second analysis. With cluster I4 subgroups $\mathrm{I}_{4} \mathrm{E}$ and $\mathrm{I} 4 \mathrm{~F}$, known to be diffuse, are not recovered in their entirety. Most of these subgroups are, therefore, taxonomically significant. This is not so with the subgroups of cluster 7 . In the second analysis well-defined subgroups of $N$. madurae strains are not found.

\section{Description of clusters obtained by using only positive matches.}

In the extensive phenotypic characterization of strains several characters were found to have a descriptive or discriminatory value. This was readily apparent when the frequency of each test which was positive in each of the clusters had been calculated (Table I4). Some features were common to almost all of the clustered strains. They were all aerobic, Grampositive, formed a primary mycelium, grew on YEA at $25^{\circ}$ to $40^{\circ}$, at reactions ranging from $\mathrm{pH} 6$ to $\mathrm{pH} 8$, and they were not inhibited by $0.00000 \mathrm{I} \%(\mathrm{w} / \mathrm{v})$ crystal violet, $0.00 \mathrm{I} \%$ $(\mathrm{w} / \mathrm{v})$ sodium azide, $3 \%(\mathrm{w} / \mathrm{v})$ sodium chloride, $0.001 \%(\mathrm{w} / \mathrm{v})$ potassium tellurite, $0.00 \mathrm{I} \%$ $(\mathrm{v} / \mathrm{v})$ Teepol or $0 . \mathrm{I} \%(\mathrm{w} / \mathrm{v})$ tetrazolium. Strains were benzidine- and catalase-positive, reduced nitrate, produced acid from glucose but not from dulcitol, inulin, melezitose or raffinose, and used sodium acetate, butyrate, propionate and paraffin as a sole source of carbon and energy.

Cluster I. These strains formed a mycelium which fragmented into rods and cocci, produced a stroma which was usually pink or orange and carried at least a trace of white aerial hyphae. Most of the strains showed some degree of acid-fastness, nearly half produced a melanin-like pigment, and nearly all had irregular colonies with filamentous margins. They degraded urea and allantoin, were resistant to lysozyme, to $5 \%(\mathrm{w} / \mathrm{v})$ sodium chloride, and to the lower concentrations of the other inhibitors used. They hydrolysed aesculin and Tweens 20, 40 and 60, and produced acid from D-fructose, mannose, arbutin, dextrin and glycerol though generally their fermentative activity was limited. The screening of carbon and energy sources revealed unrecognized nutritional characters. For instance, most strains were able to grow well on sebacic acid and testosterone, and more than half on adipic acid, as well as on sodium- $H$-malate, pyruvate and succinate. Alternatively, the strains were unable to use amino or aromatic acids, phenol or phenolic derivatives as sole carbon sources.

Cluster 2. All strains in this cluster formed a mycelium which fragmented, were acid-fast, produced a brown exopigment and formed aerial hyphae which only rarely covered the creamy/white stroma. The colonies were irregular and margins filamentous. Aesculin, guanine, hypoxanthine, xanthine and most of the Tweens were hydrolysed and acid formed from $D$-fructose, mannose, arbutin, glycerol, mannitol and inositol. The strains grew in the presence of $7 \%(\mathrm{w} / \mathrm{v})$ sodium chloride, $0.01 \%(\mathrm{w} / \mathrm{v})$ bismuth citrate and $0.05 \%(\mathrm{w} / \mathrm{v})$ potassium tellurite. The spectrum of activity towards the biochemical and nutritional tests mirrored that shown by Nocardia asteroides strains.

Cluster 5. Nocardia brasiliensis strains formed a mycelium which fragmented into rods and cocci, produced a brown exopigment, were strongly acid-fast and produced aerial hyphae which frequently covered the orange/brown stroma in a white down. They were fermentatively active and acid was produced from D-arabinose, D-galactose, D-fructose, mannose, trehalose, arbutin, glycerol, mannitol and inositol. Exocellular proteases degraded casein, gelatin and keratin; aesculin, deoxyribonucleic acid, guanine, hypoxanthine and tyrosine were also readily degraded. Strains in this cluster had similar biochemical and nutritional properties to $N$. asteroides and $N$. caviae, but unlike them utilized sodium gluconate, Lproline and L-tyrosine as sole sources of carbon and energy. 
Cluster 7 . The strains in this cluster were not acid-fast, grew slowly producing a mycelium which generally did not fragment, nearly half formed a brown exopigment, but only a few formed aerial hyphae, and even then only feebly. The colonies were white/cream and the margins deeply filamentous. The Nocardia madurae strains formed acid from D-xylose, L-rhamnose, D-galactose, maltose, trehalose, arbutin, mannitol and less readily from adonitol and mannose. Casein, gelatin, keratin, aesculin, hypoxanthine, tyrosine and Tweens 20, 40 and 60 were readily degraded; adenine, guanine and deoxyribonucleic acid less so. Urea was also broken down but the strains showed no distinctive biochemical or nutritional properties.

Cluster $8 \mathrm{~A}$. The Nocardia pelletieri strains were slow growers, difficult to cultivate, formed a permanent mycelium and occasionally a characteristic red exopigment. Aerial hyphae were only feebly produced, and under strongly aerobic conditions a reddish, frequently deep red, stroma, though white mutants were not uncommon. Acid was produced from trehalose but from few other sugars, and casein, gelatin, keratin, deoxyribonucleic acid, hypoxanthine, tyrosine and chitin were degraded. The organisms grew on a range of carbon sources which included sebacic acid, sodium- $H$-malate, pyruvate, gluconate, citrate and L-proline but were inhibited by lysozyme and low concentrations of bismuth citrate, thallous acetate, tetrazolium and penicillin.

Cluster Io $A$. The Nocardia turbata strains were non-acid fast and formed a primary mycelium which fragmented into flagellated motile rods. The colonies were smooth, yellow, convex and had deeply filamentous margins. They were very active fermentatively, produced acid from glucose anaerobically and from most of the sugars and sugar alcohols examined, including cellobiose, sucrose, glycogen and amygdalin. Aesculin, casein, gelatin, keratin, chitin, deoxyribonucleic acid and Tweens 20, 40 and 60 were degraded and urea and allantoin broken down. The carbon utilization pattern was limited though growth occurred on sodium lactate and gluconate, and readily in media containing $7 \%(\mathrm{w} / \mathrm{v})$ sodium chloride, $0.4 \%$ $(\mathrm{v} / \mathrm{v})$ phenyl ethanol, $\mathrm{O} \cdot \mathrm{I} \%(\mathrm{w} / \mathrm{v})$ phenol and $0.0 \mathrm{r} \%(\mathrm{w} / \mathrm{v})$ bismuth citrate.

Cluster I4. Most of the strains in this large cluster formed a primary mycelium which soon fragmented into rods and cocci; aerial hyphae when produced were short and sparse. A few strains were weakly acid-fast, and most colonies were pink, orange or red, though this property was not stable. Acid was readily produced from maltose, D-fructose, mannose and glycerol and less so from sucrose, trehalose, arbutin and sorbitol. Most strains degraded Tweens 20, 40 and 60 and approximately half adenine, deoxyribonucleic acid, tyrosine, urea and allantoin. Sodium-D-tartrate and pyruvate were utilized by most of the organisms though a wide range of carbon sources were used by the cluster as a whole. The Mycobacterium rhodochrous strains were sensitive to lysozyme and penicillin but grew in the presence of $5 \%(\mathrm{w} / \mathrm{v})$ sodium chloride, $0.01 \%(\mathrm{w} / \mathrm{v})$ sodium azide, $0.4 \%(\mathrm{v} / \mathrm{v})$ phenyl ethanol and $0.0 \mathrm{I} \%$ $(\mathrm{w} / \mathrm{v})$ potassium tellurite.

The minor clusters. Unfortunately these clusters were represented by only two or three strains so that the weight which can be attached to character attributes they show is uncertain. Nevertheless the characters which might be important in describing these groups will be mentioned. The Nocardia gardneri strains of cluster 4 shared a relatively high general similarity with $N$. asteroides and this was reflected in their properties. They were acid-fast, formed a mycelium which fragmented, produced a brown exopigment and a moderate amount of white aerial hyphae. They formed acid from D-fructose, mannose, sucrose, maltose, arbutin, glycerol, sorbitol and dextrin and degraded Tweens 20, 40 and 60, and urea and allantoin. They grew in media which contained $3 \%(\mathrm{w} / \mathrm{v})$ sodium chloride, $0 \cdot \mathrm{I} \%(\mathrm{w} / \mathrm{v})$ phenol and the lower concentration of the other inhibitors, and utilized sodium acetate, citrate, butyrate, succinate, adipic and sebacic acids as sole carbon sources. 
The Nocardia formica strains of cluster 6 formed a mycelium which fragmented, a brown exopigment, a moderate amount of aerial hyphae; they were not acid-fast but were active fermentatively and biochemically. Nitrate, allantoin and urea were decomposed, and acid formed from D-fructose, D-galactose, lactose, maltose, trehalose, glycogen and inositol. Adenine, casein, gelatin, keratin, deoxyribonucleic acid, guanine, hypoxanthine and Tweens 20,40 and 60 were degraded, and the compounds listed for cluster 4 utilized as sole carbon sources.

The two Streptomyces somaliensis strains in cluster 9 had a permanent mycelium, were non-acid-fast and produced abundant white aerial hyphae some of which carried long chains of spores. Acid was produced from mannose, maltose and dextrin, and Tweens 20, 40 and 60, casein, gelatin, keratin and deoxyribonucleic acid were degraded. The organisms were sensitive to bismuth citrate, penicillin and lysozyme, and utilized sodium acetate, citrate, propionate, L-tyrosine and paraffin as sole sources of carbon.

Cluster I I contains the Nocardia vaccinii strains, which were acid-fast, formed a mycelium which fragmented, produced an exopigment, and a red stroma covered with white aerial hyphae. Acid was produced from L-arabinose, D-xylose, L-rhamnose, D-fructose, D-galactose, mannose, cellobiose, sucrose, trehalose, glycerol and mannitol. Cellulose, chitin, deoxyribonucleic acid, urea and Tweens 20, 40 and 60 were degraded. These strains were sensitive to penicillin, resistant to lysozyme and used sodium lactate, $H$-malate, malonate and octoate, as well as more commonly used carbon compounds.

The Nocardia coeliaca strains of cluster 12 were acid-fast, produced a mycelium which fragmented, abundant aerial hyphae and a brown diffusible exopigment. They formed acid from maltose, melezitose, salicin and ethanol as well as from all the sugars attacked by N. vaccinii. Adenine, gelatin, casein, guanine, hypoxanthine, tyrosine and xanthine were degraded. The strains broke down urea and allantoin, were not inhibited by lysozyme or penicillin, and utilized as sole carbon sources all the compounds used by $N$.asteroides and N. vaccinii.

The three Nocardia dassonvillei strains in cluster $\mathrm{I} 3$ were not acid-fast, formed a mycelium which fragmented into rods and cocci, produced an exopigment and abundant aerial hyphae some of which segmented into chains of spores. Acid was formed from L-arabinose, Dxylose, L-rhamnose, D-fructose, D-galactose, mannose, cellobiose, sucrose, maltose, glycogen, arbutin, glycerol and mannitol. All the organic compounds were hydrolysed with the exception of cellulose, chitin, Tween 80 and xylan. The organisms were sensitive to lysozyme and penicillin, and utilized a wide range of carbon sources as sole source of carbon, including sodium lactate and tartrate.

The four remaining minor clusters are those which were defined in the second computer analysis when positive matches alone were considered. One of them contains the Dermatophilus strains, which were unreactive to most of the tests but were recognized by the way in which the hyphae liberated motile coccoid elements. They degraded casein, gelatin, keratin, urea and allantoin.

The Nocardia marina strains were nonacid-fast, formed a mycelium which fragmented and produced yellow convex colonies with entire margins. Acid was produced from D-fructose, mannose, sucrose, maltose, trehalose, glycogen, mannitol and sorbitol, and adenine, cellulose, chitin, gelatin, keratin and Tweens 20, 40 and 60 degraded. They reduced nitrate, produced urease and allantoinase, grew on sodium acetate, propionate and lactate, and in the presence of $10 \%(\mathrm{w} / \mathrm{v})$ sodium chloride but were sensitive to penicillin and lysozyme.

The Nocardia rhodnii strains had many characters in common with $N$. asteroides. They were nonacid-fast, had a mycelium which fragmented and formed an orange stroma which 
Table 14. Percentage frequency of positive characters found in major clusters defined at the $80 \%$ similarity level

\begin{tabular}{|c|c|c|c|c|c|c|c|c|}
\hline & & $\begin{array}{l}\text { Nocardia } \\
\text { asteroides }\end{array}$ & $\begin{array}{c}N . \\
\text { caviae }\end{array}$ & $\begin{array}{l}\text { N. bra- } \\
\text { siliensis }\end{array}$ & $\begin{array}{c}N . \\
\text { madurae }\end{array}$ & $\begin{array}{l}\text { N. pel- } \\
\text { letieri }\end{array}$ & $\begin{array}{l}\quad N \\
N . \\
\text { turbata }\end{array}$ & $\begin{array}{l}\text { Aycobac- } \\
\text { terium } \\
\text { rhodoch- } \\
\text { rous }\end{array}$ \\
\hline Clust & $\ldots$ & I & 2 & 5 & 7 & $8 \mathrm{~A}$ & IOA & I4 \\
\hline No. & of strains tested & 42 & IO & I0 & 22 & I I & 5 & 104 \\
\hline I & Mycelium, formed & 100 & 100 & 100 & 100 & 100 & 100 & $8 \mathrm{I}$ \\
\hline 2 & Mycelium, temporary & 100 & 100 & 100 & 27 & 0 & 100 & 100 \\
\hline 3 & Rods and cocci found & 100 & 100 & 100 & 27 & 0 & 100 & 96 \\
\hline 4 & Cocci only & 0 & 0 & 0 & 0 & 0 & 0 & 4 \\
\hline 5 & Rods only & 0 & 0 & 0 & 0 & 0 & 0 & 0 \\
\hline 6 & Acid-fastness, weak & 70 & 100 & 100 & o & o & 0 & 19 \\
\hline 7 & Acid-fastness, strong & 46 & 50 & 100 & 0 & 0 & 0 & 10 \\
\hline 8 & Strains motile & 0 & 0 & 0 & 0 & 0 & 80 & 0 \\
\hline 9 & Aerial hyphae, sparse & 98 & 90 & 100 & 23 & 72 & 0 & 39 \\
\hline 10 & Aerial hyphae, moderate & 77 & 60 & 100 & 14 & 9 & 0 & 7 \\
\hline 11 & Aerial hyphae, abundant & 62 & 20 & 100 & 9 & 9 & 0 & 2 \\
\hline 12 & Colonies, white/grey & 17 & 100 & 0 & 100 & 9 & 0 & 36 \\
\hline 13 & Colonies, pink/orange/red & 77 & 0 & 70 & 0 & 90 & 0 & 57 \\
\hline 14 & Colonies, black & 0 & 0 & o & o & o & 0 & 0 \\
\hline 15 & Colonies, brown & 7 & o & 30 & 0 & o & 0 & 0 \\
\hline 16 & Colonies, yellow & 0 & 0 & 0 & 0 & 0 & 100 & 6 \\
\hline 17 & Exopigment, water soluble & 43 & 90 & 100 & $4 \mathrm{I}$ & 36 & 0 & 6 \\
\hline 18 & Colony margin, entire & 0 & 0 & 0 & 0 & 0 & 0 & 73 \\
\hline 19 & Colony margin, filamentous & 48 & 100 & 100 & 2 & 100 & 20 & 20 \\
\hline 20 & Colony margin, deeply filamentous & 52 & 0 & 0 & 98 & 0 & 80 & 7 \\
\hline 21 & Colonies easy to emulsify & 0 & 30 & 20 & 0 & o & 100 & 89 \\
\hline 22 & Suspension, coarse & 100 & 100 & 100 & 100 & 100 & o & 16 \\
\hline 23 & Colony elevation, flat/raised & 0 & 0 & 0 & 0 & 0 & o & I 2 \\
\hline 24 & Colony elevation, convex & 12 & 20 & 0 & 0 & 0 & 100 & 65 \\
\hline 25 & Colony elevation, irregular & 89 & 80 & 100 & 100 & 100 & 0 & 23 \\
\hline
\end{tabular}

Acid from:

$\begin{array}{ll}26 & \text { L-Arabinose } \\ 27 & \text { D-Arabinose } \\ 28 & \text { D-Xylose } \\ 29 & \text { L-Rhamnose } \\ 30 & \text { D-Fructose } \\ 3 \text { I } & \text { D-Galactose } \\ 32 & \text { Glucose, oxidative } \\ 33 & \text { Glucose, fermentative } \\ 34 & \text { Mannose } \\ 35 & \text { Cellobiose } \\ 36 & \text { Lactose } \\ 37 & \text { Sucrose } \\ 38 & \text { Maltose } \\ 39 & \text { Trehalose } \\ 40 & \text { Melezitose } \\ 4 \text { I } & \text { Raffinose } \\ 42 & \text { Glycogen } \\ 43 & \text { Inulin } \\ 44 & \text { Amygdalin } \\ 45 & \text { Arbutin } \\ 46 & \text { Salicin } \\ 47 & \text { Adonitol } \\ 48 & \text { Dulcitol } \\ 49 & \text { Glycerol }\end{array}$

Fermentation studies

$\begin{array}{rrrrrrr}0 & 0 & 0 & 45 & 0 & 100 & \text { I I } \\ 0 & 0 & 100 & 0 & 0 & 0 & 0 \\ 0 & 0 & 0 & 100 & 0 & 80 & 5 \\ 24 & 0 & 0 & 85 & 0 & 0 & 2 \\ 98 & 100 & 100 & 21 & 54 & 100 & 89 \\ 17 & 0 & 100 & 85 & 0 & 80 & 15 \\ 98 & 100 & 100 & 100 & 90 & 100 & 92 \\ 0 & 0 & 0 & 0 & 0 & 100 & 0 \\ 86 & 40 & 100 & 50 & 0 & 100 & 84 \\ 5 & 0 & 0 & 0 & 0 & 100 & 11 \\ 0 & 0 & 0 & 0 & 0 & 80 & 5 \\ 0 & 0 & 0 & 0 & 0 & 100 & 71 \\ 53 & 50 & 0 & 91 & 18 & 100 & 84 \\ 55 & 50 & 100 & 77 & 81 & 100 & 67 \\ 0 & 0 & 0 & 0 & 0 & 0 & 4 \\ 0 & 0 & 0 & 0 & 0 & 20 & 6 \\ 0 & 0 & 0 & 0 & 0 & 100 & 5 \\ 0 & 0 & 0 & 0 & 0 & 0 & 0 \\ 0 & 0 & 0 & 0 & 0 & 100 & 9 \\ 89 & 100 & 90 & 86 & 0 & 100 & 48 \\ 17 & 0 & 10 & 0 & 0 & 100 & 22 \\ 41 & 0 & 0 & 59 & 0 & 0 & 3 \\ 0 & 0 & 0 & 0 & 0 & 0 & 0 \\ 95 & 100 & 100 & 85 & 0 & 100 & 82\end{array}$


Table I4 (cont.)

Cluster

No. of strains tested

$\begin{array}{ll}50 & \text { Mannitol } \\ 51 & \text { Sorbitol } \\ 52 & \text { meso-Inositol } \\ 53 & \text { Ethanol } \\ 54 & \text { Dextrin }\end{array}$

55 Adenine, strong

56 Adenine, weak

57 Aesculin

58 Casein, strong

59 Casein, weak

60 Cellulose

6 I Chitin

62 DNA

63 Gelatin, strong

64 Gelatin, weak

65 Guanine

66 Hippurate

67 Hypoxanthine, strong

68 Hypoxanthine, weak

69 Keratin, strong

70 Keratin, weak

71 Tween 20

72 Tween 40

73 Tween 60

74 Tween 80

75 Tyrosine, strong

76 Tyrosine, weak

77 Xanthine, strong

78 Xanthine, weak

79 Xylan

80 L-Arabinose

8 I D-Arabinose

82 D-Xylose

83 L-Rhamnose

84 D-Fructose

85 D-Galactose

86 D-Glucose

87 Mannose

88 Cellobiose

89 Lactose

90 Sucrose

9I Maltose

92 Trehalose

93 Melezitose

94 Raffinose

95 Glycogen

96 Inulin

97 Amygdalin

98 Arbutin

\section{Table it (cont)}

Mycobac-
terium

Nocardia N. N.bra- N. N.pel- N. rhodochasteroides caviae siliensis madurae letieri turbata rous

$\begin{array}{rrrrrrr}\mathrm{I} & 2 & 5 & 7 & 8 \mathrm{~A} & \mathrm{IOA} & \mathrm{I} 4 \\ 42 & \mathrm{IO} & \mathrm{IO} & 22 & \mathrm{I} \mathrm{I} & 5 & \mathrm{I04} \\ 7 & 80 & 90 & 85 & 9 & 0 & 86 \\ 2 & \mathrm{IO} & 0 & 0 & 0 & 100 & 72 \\ 0 & 100 & 100 & 18 & 0 & 0 & 16 \\ 24 & 0 & 0 & 0 & 0 & 0 & 63 \\ 93 & 40 & 0 & 85 & 72 & 100 & 88\end{array}$

Hydrolysis tests

$\begin{array}{rrrrrrr}0 & 0 & 0 & 23 & 0 & 0 & 36 \\ 0 & 0 & 0 & 23 & 0 & 0 & 48 \\ 93 & 100 & 100 & 100 & 0 & 100 & 90 \\ 0 & 0 & 60 & 59 & 90 & 40 & 12 \\ 0 & 0 & 100 & 81 & 100 & 100 & 14 \\ 0 & 0 & 0 & 5 & 0 & 20 & 0 \\ 0 & 0 & 0 & 5 & 90 & 100 & 0 \\ 0 & 30 & 100 & 72 & 90 & 100 & 63 \\ 0 & 0 & 80 & 59 & 100 & 100 & 16 \\ 0 & 0 & 100 & 100 & 100 & 100 & 24 \\ 0 & 90 & 90 & 63 & 0 & 0 & 10 \\ 0 & 0 & 0 & 0 & 0 & 0 & 0 \\ 5 & 90 & 90 & 45 & 54 & 20 & 2 \\ 5 & 90 & 100 & 81 & 100 & 20 & 3 \\ 0 & 0 & 60 & 18 & 81 & 80 & 2 \\ 0 & 0 & 100 & 81 & 100 & 80 & 4 \\ 100 & 90 & 20 & 100 & 20 & 100 & 97 \\ 97 & 70 & 10 & 100 & 9 & 100 & 93 \\ 84 & 70 & 10 & 100 & 9 & 100 & 90 \\ 10 & 20 & 0 & 14 & 0 & 0 & 12 \\ 0 & 0 & 70 & 72 & 54 & 0 & 45 \\ 0 & 0 & 100 & 91 & 100 & 0 & 51 \\ 0 & 40 & 0 & 0 & 0 & 20 & 2 \\ 0 & 100 & 0 & 0 & 0 & 20 & 3 \\ 0 & 0 & 0 & 0 & 0 & 20 & 0\end{array}$

Sole carbon source

$\begin{array}{rrrrrrr}0 & 0 & 50 & 59 & 72 & 100 & 48 \\ 0 & 0 & 20 & 0 & 0 & 0 & \text { I } \\ 0 & 0 & 30 & 91 & 0 & 100 & 58 \\ 36 & 0 & 0 & 77 & 9 & 0 & 6 \\ 91 & 100 & 80 & 63 & 0 & 100 & 80 \\ 24 & 0 & 90 & 68 & 63 & 80 & 43 \\ 100 & 100 & 100 & 100 & 100 & 100 & 95 \\ 86 & 40 & 100 & 50 & 9 & 100 & 90 \\ 0 & 30 & 0 & 18 & 0 & 100 & 21 \\ 0 & 0 & 10 & 0 & 0 & 100 & 15 \\ 7 & 20 & 70 & 14 & 0 & 100 & 70 \\ 74 & 60 & 100 & 81 & 18 & 100 & 59 \\ 26 & 40 & 100 & 95 & 90 & 100 & 72 \\ 0 & 0 & 0 & 0 & 0 & 80 & 15 \\ 0 & 0 & 0 & 0 & 0 & 20 & 11 \\ 0 & 0 & 10 & 9 & 63 & 100 & 7 \\ 0 & 0 & 0 & 0 & 0 & 0 & 2 \\ 5 & 0 & 0 & 0 & 0 & 100 & 4 \\ 0 & 60 & 50 & 14 & 0 & 0 & 5\end{array}$


Table I4 (cont.)

Cluster $\quad \ldots$

No. of strains tested $\quad$...

99 Salicin

100 Adonitol

IO I Dulcitol

I02 Glycerol

103 Mannitol

104 Sorbitol

I05 meso-Inositol

106 Dextrin

107 Starch

I08 Glucosamine

109 Sodium acetate

I IO Sodium propionate

I I Sodium- $n$-butyrate

I 2 Sodium- $n$-octoate

I13 Sodium malonate

I 4 Sodium benzoate

I 5 Sodium succinate

I 6 Adipic acid

I 7 Pimelic acid

I 8 Sebacic acid

119 Sodium lactate

I20 Sodium- $H$-malate

I 2 I Sodium-D-tartrate

I22 Sodium citrate

123 Sodium hippurate

I 24 D- $\alpha$-Alanine

$125 \mathrm{~L}-\alpha$-Alanine

126 DL-nor-Leucine

127 L-Threonine

128 L-Serine

I 29 L-Tryptophan

130 L-Proline

I 3 I L-Tyrosine

$132 p$-Hydroxybenzoic acid

$133 m$-Hydroxybenzoic acid

I 34 D-Mandelic acid

I35 Protocatechuic acid

136 Testosterone

137 Sodium pyruvate

I38 Betaine $\mathrm{HCl}$

139 Acetamide

140 Benzamide

14 I $p$-Cresol

142 Paraffin

I43 Sodium gluconate

I44 $o$-Hydroxybenzaldehyde

I45 Trimethyldiamine

146 Serine

147 Acetamide

Nocardia N. N.bra- $\quad$ N. N.pel- $\quad$ N. $\quad \begin{gathered}\text { Mycobac- } \\ \text { terium } \\ \text { rhodoch- }\end{gathered}$ asteroides caviae siliensis madurae letieri turbata rous

\begin{tabular}{|c|c|c|c|c|c|c|}
\hline I & 2 & 5 & 7 & $8 \mathrm{~A}$ & $\mathrm{IOA}$ & 14 \\
\hline 42 & 10 & 10 & 22 & I I & 5 & 104 \\
\hline 10 & 20 & 30 & 0 & 0 & 100 & 33 \\
\hline 0 & 0 & 0 & 68 & 0 & 0 & 3 \\
\hline 0 & 0 & 0 & 0 & 0 & 0 & 7 \\
\hline 82 & 10 & 90 & $8 \mathrm{I}$ & 45 & 100 & 80 \\
\hline 53 & 100 & 90 & $8 \mathrm{I}$ & 9 & 20 & 73 \\
\hline 7 & 10 & 0 & 0 & 0 & 100 & 62 \\
\hline 2 & 90 & 100 & 5 & 0 & 0 & 21 \\
\hline 50 & 50 & 10 & 40 & 0 & 100 & 35 \\
\hline $4 I$ & 40 & 50 & I4 & 9 & 100 & 47 \\
\hline 0 & 50 & 90 & 28 & 0 & 40 & 37 \\
\hline 100 & 100 & 100 & $8 I$ & 100 & 100 & 79 \\
\hline 100 & 80 & 100 & 68 & 100 & 100 & 89 \\
\hline 100 & 100 & 100 & 72 & 100 & 0 & 83 \\
\hline 0 & 0 & 0 & 0 & 0 & 0 & 35 \\
\hline 0 & 0 & 0 & 0 & 0 & 0 & o \\
\hline 12 & 0 & 0 & 0 & 0 & 0 & 27 \\
\hline 100 & 100 & 80 & $8 \mathrm{I}$ & 63 & 0 & 73 \\
\hline 53 & 0 & 0 & 0 & 0 & 0 & 56 \\
\hline 0 & 0 & 10 & 0 & 9 & 0 & 42 \\
\hline 84 & 100 & 90 & 0 & 90 & 0 & 54 \\
\hline 0 & 0 & 0 & 0 & 0 & 100 & 55 \\
\hline 98 & 100 & IOO & 68 & 100 & 0 & 73 \\
\hline 0 & 0 & 0 & 0 & 0 & 0 & 90 \\
\hline I 2 & 50 & 90 & 45 & 90 & 0 & 69 \\
\hline 0 & 0 & 0 & 0 & 0 & 0 & 2 \\
\hline 0 & 0 & 10 & 9 & 9 & 0 & $4 I$ \\
\hline 0 & 60 & 50 & 9 & 36 & 0 & 40 \\
\hline 0 & 0 & 0 & 0 & 0 & 0 & 36 \\
\hline 0 & 0 & c & 0 & 0 & 0 & 9 \\
\hline 0 & 50 & 40 & 0 & 27 & 0 & 27 \\
\hline 0 & 0 & 0 & 0 & 0 & 0 & 0 \\
\hline 0 & o & 90 & 18 & 90 & 0 & 3 I \\
\hline 0 & 0 & 70 & 9 & 54 & 0 & $3 I$ \\
\hline 0 & 0 & 0 & 0 & 0 & 0 & 43 \\
\hline 14 & 0 & 0 & 0 & 0 & 0 & 3 I \\
\hline 0 & 0 & 0 & 0 & 0 & 0 & I \\
\hline 7 & 0 & 30 & 0 & 27 & 20 & 60 \\
\hline 82 & 100 & 0 & 0 & 0 & 0 & 57 \\
\hline 100 & 100 & 100 & 50 & 100 & 100 & 83 \\
\hline 0 & 0 & 0 & 0 & 0 & 0 & 2 \\
\hline 7 & IO & 0 & 0 & 0 & 0 & $5^{8}$ \\
\hline 0 & 0 & 0 & 0 & 0 & 0 & 8 \\
\hline 2 & 10 & 0 & 0 & 0 & 0 & 33 \\
\hline 100 & 90 & 100 & IOO & 90 & 100 & 84 \\
\hline 0 & 0 & 90 & 55 & $8 I$ & 100 & 62 \\
\hline 0 & 0 & 0 & 0 & 0 & 0 & 23 \\
\hline
\end{tabular}

Sole carbon and nitrogen source

$\begin{array}{rrrrrrr}0 & 0 & 0 & 5 & 0 & 0 & 2 \\ 0 & 0 & 70 & 0 & 0 & 0 & 0 \\ 14 & 0 & 50 & 14 & 0 & 0 & 31\end{array}$


Table 14 (cont.)

Cluster

No. of strains tested ...

\begin{tabular}{|c|c|c|c|c|c|c|}
\hline $\begin{array}{l}\text { Nocardia } \\
\text { asteroides }\end{array}$ & $\begin{array}{c}N . \\
\text { caviae }\end{array}$ & $\begin{array}{l}\text { N. bra- } \\
\text { siliensis }\end{array}$ & $\begin{array}{c}N . \\
\text { madurae }\end{array}$ & $\begin{array}{l}\text { N.pel- } \\
\text { letieri }\end{array}$ & $\begin{array}{c}\text { N. } \\
\text { turbata }\end{array}$ & $\begin{array}{c}\text { Mycobac- } \\
\text { terium } \\
\text { rhodoch- } \\
\text { rous }\end{array}$ \\
\hline I & 2 & 5 & 7 & $8 \mathrm{~A}$ & $10 \mathrm{~A}$ & 14 \\
\hline 42 & IO & 10 & 22 & I I & 5 & 104 \\
\hline
\end{tabular}

Growth on YEA containing:

\begin{tabular}{|c|c|}
\hline 148 & $3 \%(w / v) \mathrm{NaCl}$ \\
\hline 149 & $5 \%(\mathrm{w} / \mathrm{v}) \mathrm{NaCl}$ \\
\hline 150 & $7 \%(w / v) \mathrm{NaCl}$ \\
\hline $15 \mathrm{I}$ & $10 \%(w / v) \mathrm{NaCl}$ \\
\hline 152 & $0.001 \%(\mathrm{w} / \mathrm{v})$ sodium azide \\
\hline 153 & $0.01 \%(\mathrm{w} / \mathrm{v})$ sodium azide \\
\hline 154 & $0.02 \%(\mathrm{w} / \mathrm{v})$ sodium azide \\
\hline I 55 & $0.03 \%(w / v)$ sodium azide \\
\hline I 56 & $0.001 \%(\mathrm{w} / \mathrm{v})$ potassium tellurite \\
\hline 157 & $0.01 \%(\mathrm{w} / \mathrm{v})$ potassium tellurite \\
\hline 158 & $0.05 \%(\mathrm{w} / \mathrm{v})$ potassium tellurite \\
\hline 159 & $0.1 \%(\mathrm{w} / \mathrm{v})$ potassium tellurite \\
\hline 160 & $0.1 \%(v / v)$ phenyl ethanol \\
\hline I 6I & $0.2 \%(v / v)$ phenyl ethanol \\
\hline 162 & $0.3 \%(v / v)$ phenyl ethanol \\
\hline 163 & $0.4 \%(\mathrm{v} / \mathrm{v})$ phenyl ethanol \\
\hline 164 & $0.000001 \%(w / v)$ crystal violet \\
\hline 165 & $0.00001 \%(\mathrm{w} / \mathrm{v})$ crystal violet \\
\hline I 66 & $0.000 \mathrm{I} \%(\mathrm{w} / \mathrm{v})$ crystal violet \\
\hline I 67 & $0.00 \mathrm{I} \%(\mathrm{w} / \mathrm{v})$ crystal violet \\
\hline 168 & $0.001 \%(v / v)$ Teepol \\
\hline 169 & $0.005 \%(v / v)$ Teepol \\
\hline 170 & $0.01 \%(\mathrm{v} / \mathrm{v})$ Teepol \\
\hline 171 & $0.001 \%(\mathrm{w} / \mathrm{v})$ phenol \\
\hline 172 & $0.01 \%(w / v)$ phenol \\
\hline 173 & $0.1 \%(\mathrm{w} / \mathrm{v})$ phenol \\
\hline 174 & $0.0001 \%(\mathrm{w} / \mathrm{v})$ bismuth citrate \\
\hline 175 & $0.001 \%(\mathrm{w} / \mathrm{v})$ bismuth citrate \\
\hline 176 & $0.01 \%(\mathrm{w} / \mathrm{v})$ bismuth citrate \\
\hline 177 & $0.0001 \%(\mathrm{w} / \mathrm{v})$ thallous acetate \\
\hline 178 & $0.001 \%(\mathrm{w} / \mathrm{v})$ thallous acetate \\
\hline 179 & $0.01 \%(\mathrm{w} / \mathrm{v})$ thallous acetate \\
\hline 180 & $0.01 \%(\mathrm{w} / \mathrm{v})$ tetrazolium \\
\hline $18 r$ & $0.1 \%(w / v)$ tetrazolium \\
\hline 182 & Sensitivity to penicillin \\
\hline & Growth at: \\
\hline 183 & $\mathrm{pH} 5$ \\
\hline 184 & $\mathrm{pH} 6$ \\
\hline I 85 & $\mathrm{pH} 8$ \\
\hline 186 & $\mathrm{pH} 9$ \\
\hline I 87 & $\mathrm{pH}$ io \\
\hline I 88 & $50^{\circ}$ \\
\hline 189 & $45^{\circ}$ \\
\hline 190 & 40 \\
\hline 191 & $35^{\circ}$ \\
\hline 192 & $10^{\circ}$ \\
\hline
\end{tabular}

$\begin{array}{rrrrrrr}100 & 100 & 100 & 100 & 100 & 100 & 94 \\ 84 & 100 & 100 & 72 & 100 & 100 & 83 \\ 36 & 80 & 0 & 40 & 0 & 100 & 69 \\ 0 & 0 & 0 & 9 & 0 & 0 & 9 \\ 100 & 100 & 100 & 100 & 100 & 100 & 100 \\ 62 & 40 & 30 & 50 & 9 & 100 & 83 \\ 12 & 0 & 0 & 0 & 0 & 80 & 54 \\ 0 & 0 & 0 & 0 & 0 & 60 & 2 \\ 100 & 100 & 100 & 100 & 100 & 100 & 95 \\ 79 & 80 & 30 & 59 & 27 & 60 & 88 \\ 60 & 70 & 20 & 23 & 18 & 0 & 62 \\ 41 & 10 & 0 & 9 & 0 & 0 & 38 \\ 89 & 100 & 70 & 100 & 54 & 100 & 97 \\ 43 & 60 & 50 & 59 & 36 & 100 & 90 \\ 22 & 40 & 20 & 27 & 18 & 100 & 79 \\ 0 & 10 & 0 & 0 & 0 & 100 & 71 \\ 100 & 100 & 100 & 91 & 100 & 100 & 9 \mathrm{I} \\ 84 & 100 & 100 & 63 & 100 & 100 & 89 \\ 38 & 50 & 10 & 0 & 9 & 0 & 48 \\ 2 & 10 & 0 & 0 & 0 & 0 & 1 \mathrm{I} \\ 95 & 100 & 100 & 100 & 100 & 100 & 97 \\ 75 & 100 & 100 & 95 & 100 & 100 & 90 \\ 70 & 60 & 80 & 36 & 0 & 100 & 77 \\ 100 & 100 & 100 & 100 & 27 & 100 & 98 \\ 86 & 90 & 100 & 54 & 0 & 100 & 86 \\ 43 & 50 & 30 & 14 & 0 & 100 & 46 \\ 95 & 100 & 100 & 72 & 0 & 100 & 95 \\ 90 & 100 & 100 & 27 & 0 & 100 & 83 \\ 43 & 90 & 100 & 5 & 0 & 100 & 39 \\ 100 & 100 & 90 & 91 & 18 & 100 & 91 \\ 5 & 20 & 0 & 5 & 0 & 100 & 19 \\ 0 & 0 & 0 & 0 & 0 & 80 & 2 \\ 95 & 80 & 100 & 22 & 0 & 100 & 90 \\ 0 & 0 & 0 & 0 & 0 & 0 & 2 \\ 24 & 30 & 10 & 81 & 100 & 100 & 98 \\ & & & & & & \\ 2 & 0 & 0 & 0 & 0 & 0 & 2 \\ 98 & 100 & 100 & 72 & 100 & 40 & 94 \\ 100 & 100 & 100 & 8 \mathrm{I} & 8 \mathrm{I} & 100 & 95 \\ 98 & 100 & 100 & 50 & 27 & 100 & 86 \\ 62 & 100 & 30 & 23 & 0 & 20 & 79 \\ 31 & 10 & 0 & 5 & 27 & 0 & 3 \\ 64 & 60 & 20 & 45 & 90 & 0 & 9 \\ 100 & 90 & 90 & 100 & 100 & 100 & 90 \\ 100 & 100 & 100 & 100 & 100 & 100 & 89 \\ 26 & 30 & 60 & 0 & 9 & 100 & 83\end{array}$




\section{Table I4 (cont.)}

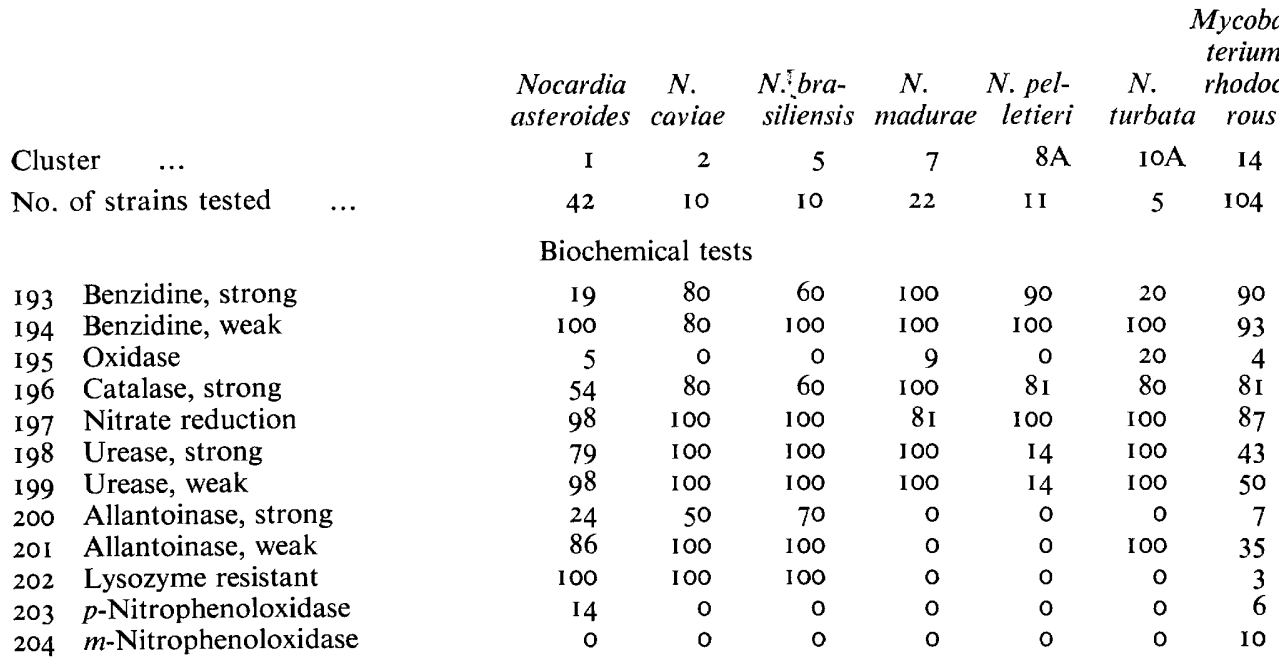

Table I5. Characters which serve to differentiate major clusters

\begin{tabular}{|c|c|c|c|c|c|c|c|}
\hline & $\begin{array}{l}\text { Nocardia } \\
\text { asteroides }\end{array}$ & $\begin{array}{c}N . \\
\text { caviae }\end{array}$ & $\begin{array}{l}N . \text { bra- } \\
\text { siliensis }\end{array}$ & $\begin{array}{l}\text { N. mad- } \\
\text { urae }\end{array}$ & $\begin{array}{l}\text { N. pel- } \\
\text { letieri }\end{array}$ & $\begin{array}{c}N . \\
\text { turbata }\end{array}$ & $\begin{array}{c}\text { Mycobac- } \\
\text { terium } \\
\text { rhodoch- } \\
\text { rous }\end{array}$ \\
\hline Cluster & I & 2 & 5 & 7 & $8 \mathrm{~A}$ & IOA & 14 \\
\hline No. of strains tested & 42 & IO & 10 & 22 & II & 5 & I04 \\
\hline 2 Mycelium, temporary & + & + & + & $d$ & - & + & + \\
\hline 6 Acid-fastness, weak & $d$ & + & + & - & - & - & - \\
\hline 8 Strains motile & - & - & - & - & - & + & - \\
\hline 9 Aerial hyphae, sparse & + & + & + & $d$ & $d$ & - & $d$ \\
\hline I 6 Colonies, yellow & - & - & - & - & - & + & - \\
\hline I7 Exopigment, water soluble & $d$ & t & + & $d$ & $d$ & - & - \\
\hline
\end{tabular}

Acid from:

$\begin{array}{ll}26 & \text { L-Arabinose } \\ 27 & \text { D-Arabinose } \\ 28 & \text { D-Xylose } \\ 29 & \text { L-Rhamnose } \\ 31 & \text { D-Galactose } \\ 33 & \text { D-Glucose, fermentative } \\ 35 & \text { Cellobiose } \\ 36 & \text { Lactose } \\ 37 & \text { Sucrose } \\ 38 & \text { Maltose } \\ 42 & \text { Glycogen } \\ 44 & \text { Amygdalin } \\ 46 & \text { Salicin } \\ 49 & \text { Glycerol } \\ 50 & \text { Mannitol } \\ 5 \text { I } & \text { Sorbitol } \\ 52 & \text { meso-Inositol }\end{array}$

Fermentation studies

$\begin{array}{lllllll}- & - & - & d & - & + & - \\ - & - & + & - & - & - & - \\ - & - & - & + & - & + & - \\ d & - & - & + & - & - & - \\ - & - & + & + & - & + & - \\ - & - & - & - & - & + & - \\ - & - & - & - & - & + & - \\ - & - & - & - & - & + & - \\ - & - & - & - & - & + & d \\ d & d & - & + & - & + & + \\ - & - & - & - & - & + & - \\ - & - & - & - & - & + & - \\ - & - & - & - & - & + & d \\ + & + & + & + & - & + & + \\ - & + & + & + & - & - & d \\ - & - & - & - & - & + & d \\ - & + & + & - & - & - & -\end{array}$


Cluster ...

No. of strains tested ...

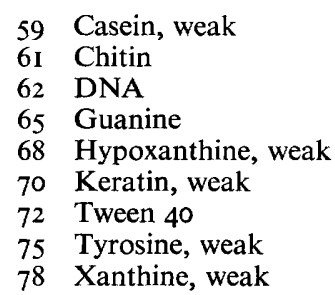

$\begin{aligned} 82 & \text { D-Xylose } \\ 85 & \text { D-Galactose } \\ 87 & \text { Mannose } \\ 88 & \text { Cellobiose } \\ 89 & \text { Lactose } \\ 90 & \text { Sucrose } \\ 93 & \text { Melezitose } \\ 95 & \text { Glycogen } \\ 97 & \text { Amygdalin } \\ 99 & \text { Salicin } \\ \text { I03 } & \text { Mannitol } \\ \text { 104 } & \text { Sorbitol } \\ \text { I05 } & \text { meso-Inositol } \\ \text { I08 } & \text { Glucosamine } \\ \text { I I } & \text { Sodium- } n \text {-butyrate } \\ \text { I I5 } & \text { Sodium succinate } \\ \text { I } 8 & \text { Sebacic acid } \\ \text { I 19 } & \text { Sodium lactate } \\ \text { I20 } & \text { Sodium- } H \text {-malate } \\ \text { I2 I } & \text { Sodium tartrate } \\ \text { I22 } & \text { Sodium citrate } \\ \text { I30 } & \text { L-Proline } \\ \text { I36 } & \text { Testosterone } \\ \text { I43 } & \text { Sodium gluconate }\end{aligned}$

I $507 \%(w / v)$ sodium chloride $163 \quad 0.4 \%(\mathrm{w} / \mathrm{v})$ phenyl ethanol

I $720.01 \%(\mathrm{w} / \mathrm{v})$ phenol

I $770.001 \%(\mathrm{w} / \mathrm{v})$ thallous acetate

I 82 Sensitivity to penicillin

199 Urease, weak

20 I Allantoinase, weak

202 Lysozyme resistant
Table 15 (cont.)

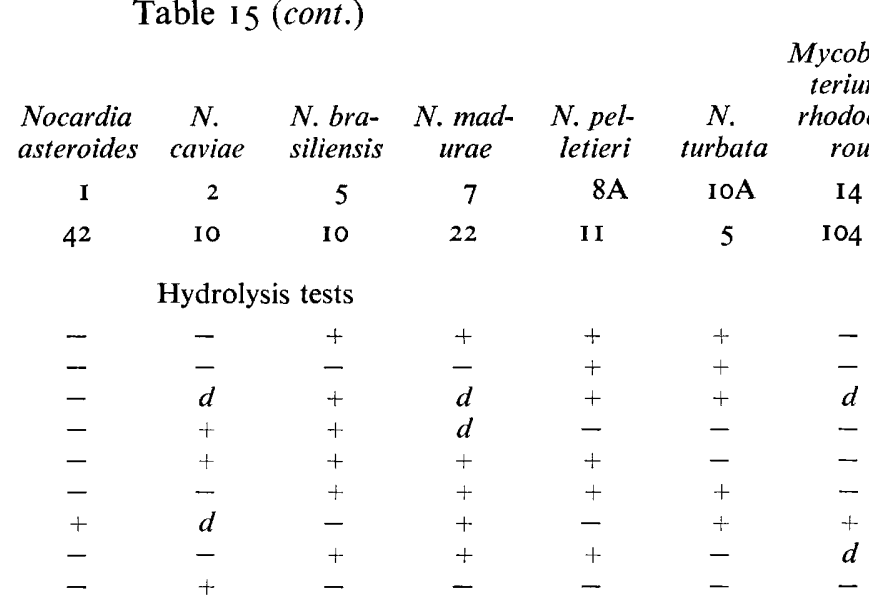

Sole carbon source

$\begin{array}{lllllll}- & - & d & + & - & + & d \\ d & - & + & d & d & + & d \\ + & d & + & d & - & + & + \\ - & d & - & - & - & + & d \\ - & - & - & - & - & + & - \\ - & d & d & - & - & + & d \\ - & - & - & - & - & + & - \\ - & - & - & - & d & + & - \\ - & - & - & - & - & + & - \\ - & d & d & - & - & + & d \\ d & + & + & + & - & d & d \\ - & - & - & - & - & + & d \\ - & + & + & - & - & - & d \\ - & d & + & d & - & d & d \\ + & + & + & d & + & - & + \\ + & - & + & + & d & - & d \\ + & - & + & - & + & - & d \\ - & - & - & - & - & + & d \\ + & + & + & d & + & - & d \\ - & - & - & - & - & - & + \\ - & d & + & d & + & - & d \\ - & - & + & d & + & - & d \\ + & + & - & - & - & - & d \\ - & - & + & d & + & + & d\end{array}$

Inhibition tests

$\begin{array}{lllllll}d & + & - & d & - & + & d \\ - & - & - & - & - & + & d \\ + & + & + & d & - & + & + \\ + & + & + & + & - & + & + \\ d & d & - & + & + & + & +\end{array}$

Biochemical tests

$\begin{array}{lllllll}+ & + & + & + & - & + & d \\ + & + & + & - & - & + & d \\ + & + & + & - & - & - & -\end{array}$


showed no trace of aerial hyphae. They produced acid from D-fructose, mannose, sucrose, maltose, trehalose, mannitol, sorbitol and ethanol, reduced nitrate, and degraded allantoin, urea and Tweens 20, 40,60 and 80. They used sodium acetate, $n$-butyrate, propionate, $n$ octoate, $\mathrm{H}$-malate, tartrate, adipic and sebacic acid as sole sources of carbon and energy but were inhibited by penicillin and lysozyme.

The final minor cluster contains Nocardia pasteuroides and $N$. convoluta (N95). These strains formed a mycelium which fragmented, and an orange stroma covered with white aerial hyphae. They formed acid from D-fructose, D-galactose, mannose, glycerol and mannitol, reduced nitrate and degraded Tweens 20,40 and 60 . The strains were resistant to lysozyme and penicillin and used sodium acetate, $n$-butyrate, propionate, succinate, pimelic acid, testosterone and $m$-hydroxybenzoic acid as sole sources of carbon and energy.

\section{Identification of major clusters.}

Characters considered to have a presumptive diagnostic value were extracted from Table I4. Some clusters encompassed a wide range of variation so it is not surprising that few unit characters were cluster-specific. Nevertheless there is sufficient consistency within clusters and differences between them for some characters to be weighted for identification. In selecting the distinguishing characters those which were $80 \%$ or more positive within a cluster were designated + , those $20 \%$ negative or below --, and those with values ranging between $21 \%$ and $79 \%$ were scored $d$ for doubtful. The 64 phenotypic characters most useful for differentiating between clusters are shown in Table I5. It can be seen that some of the tests used for the first time are found to strengthen differentiation between clusters. These include the chitin, deoxyribonucleic acid, guanine and keratin hydrolysis tests, and such nutritional characters as the use of sebacic acid and testosterone as sole sources of carbon and energy. Growth on sugar and sugar alcohols as sole carbon sources were not considered for inclusion in Table I 5 because the results of these tests were almost the same as those of the fermentation studies where the same carbohydrates were used.

By using the diagnostic characters all the isolates can be placed in the correct cluster. For

Table 16. Diagnostic table for the identification of nocardioform organisms

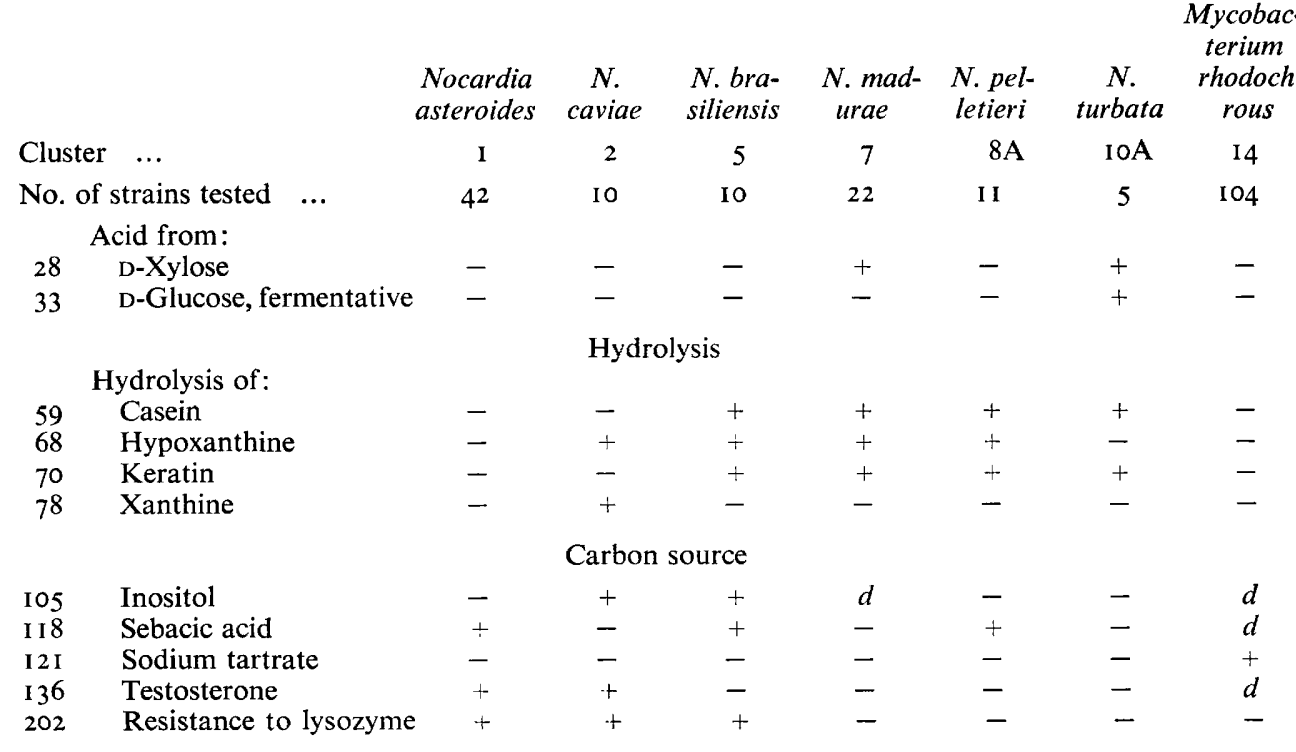


Table 17. Percentage frequency of positive characters found in subgroups of clusters $\mathrm{I}$ and 2

Cluster ...

Subgroup ...

No. of strains tested ...

I Mycelium, formed

2 Mycelium, temporary

3 Rods and cocci found

4 Cocci only

5 Rods only

6 Acid-fastness, weak

7 Acid-fastness, strong

8 Strains motile

9 Aerial hyphae, sparse

Io Aerial hyphae, moderate

I I Aerial hyphae, abundant

I 2 Colonies, white/grey

I3 Colonies, pink/orange/red

I4 Colonies, black

I5 Colonies, brown

I6 Colonies, yellow

17 Exopigment, water-soluble

I 8 Colony margin, entire

I9 Colony margin, filamentous

20 Colony margin, deeply filamentous

2 I Colonies easy to emulsify

2 Suspension, coarse

23 Colony elevation, flat/raised

24 Colony elevation, convex

25 Colony elevation, irregular

$$
100
$$

$$
\text { I }
$$
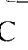

6

oo

100
100

100

100

o

0

100

100

100
0

100

0

0
100

0

0

0

0

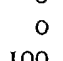

100

0

100

0

(1)

100

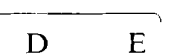

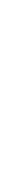

$\begin{array}{rr}A & \text { B } \\ 4 & 6 \\ 100 & 100 \\ 100 & 100 \\ 100 & 100 \\ 0 & 0 \\ 0 & 0 \\ 100 & 100 \\ 0 & 83 \\ 0 & 0 \\ 100 & 83 \\ 50 & 50 \\ 0 & 33 \\ 100 & 100 \\ 0 & 0 \\ 0 & 0 \\ 0 & 0 \\ 0 & 0 \\ 75 & 100 \\ 0 & 0 \\ 100 & 100 \\ 0 & 0 \\ 0 & 50 \\ 100 & 100 \\ 0 & 0 \\ 0 & 33 \\ 100 & 67\end{array}$

Acid from:

$\begin{array}{ll}26 & \text { L-Arabinose } \\ 27 & \text { D-Arabinose } \\ 28 & \text { D-Xylose } \\ 29 & \text { L-Rhamnose } \\ 30 & \text { D-Fructose } \\ 3 \text { I } & \text { D-Galactose } \\ 32 & \text { D-Glucose, oxidative } \\ 33 & \text { D-Glucose, fermentative } \\ 34 & \text { Mannose } \\ 35 & \text { Cellobiose } \\ 36 & \text { Lactose } \\ 37 & \text { Sucrose } \\ 38 & \text { Maltose } \\ 39 & \text { Trehalose } \\ 40 & \text { Melezitose } \\ 4 \text { I } & \text { Raffinose } \\ 42 & \text { Glycogen } \\ 43 & \text { Inulin } \\ 44 & \text { Amygdalin } \\ 45 & \text { Arbutin } \\ 46 & \text { Salicin } \\ 47 & \text { Adonitol } \\ 48 & \text { Dulcitol } \\ 49 & \text { Glycerol } \\ 50 & \text { Mannitol } \\ 51 & \text { Sorbitol } \\ & \end{array}$

Fermentation studies

$\begin{array}{rrr}0 & 0 & 0 \\ 0 & 0 & 0 \\ 0 & 0 & 0 \\ 45 & 20 & 0 \\ 100 & 90 & 100 \\ 22 & 30 & 0 \\ 100 & 90 & 100 \\ 0 & 0 & 0 \\ 95 & 60 & 100 \\ 0 & 10 & 0 \\ 0 & 0 & 0 \\ 0 & 0 & 0 \\ 39 & 70 & 34 \\ 39 & 10 & 0 \\ 0 & 0 & 0 \\ 0 & 0 & 0 \\ 0 & 0 & 0 \\ 0 & 0 & 0 \\ 0 & 0 & 0 \\ 95 & 80 & 67 \\ 12 & 20 & 0 \\ 95 & 0 & 0 \\ 0 & 0 & 0 \\ 95 & 90 & 67 \\ 6 & 0 & 34 \\ 0 & 6 & 0\end{array}$

$\begin{array}{rrrr}0 & 0 & 0 & 0 \\ 0 & 0 & 0 & 0 \\ 0 & 0 & 0 & 0 \\ 0 & 0 & 0 & 0 \\ 100 & 100 & 100 & 100 \\ 25 & 0 & 0 & 0 \\ 100 & 100 & 100 & 100 \\ 0 & 0 & 0 & 0 \\ 100 & 100 & 100 & 0 \\ 25 & 0 & 0 & 0 \\ 0 & 0 & 0 & 0 \\ 0 & 0 & 0 & 0 \\ 100 & 0 & 25 & 67 \\ 50 & 0 & 0 & 83 \\ 0 & 0 & 0 & 0 \\ 0 & 0 & 0 & 0 \\ 0 & 0 & 0 & 0 \\ 0 & 0 & 0 & 0 \\ 0 & 0 & 0 & 0 \\ 75 & 100 & 100 & 100 \\ 50 & 100 & 0 & 0 \\ 0 & 0 & 0 & 0 \\ 0 & 0 & 0 & 0 \\ 100 & 100 & 100 & 100 \\ 0 & 0 & 100 & 67 \\ 0 & 0 & 0 & 17\end{array}$


Table I 7 (cont.)

Cluster ...

No. of strains tested ...

$\begin{array}{ll}52 & \text { Inositol } \\ 53 & \text { Ethanol } \\ 54 & \text { Dextrin }\end{array}$

55 Adenine, strong

56 Adenine, weak

57 Aesculin

58 Casein, strong

59 Casein, weak

60 Cellulose

6I Chitin

62 DNA

63 Gelatin, strong

64 Gelatin, weak

65 Guanine

66 Hippurate

67 Hypoxanthine, strong

68 Hypoxanthine, weak

69 Keratin, strong

70 Keratin, weak

7 I Tween 20

72 Tween 40

73 Tween 60

74 Tween 80

75 Tyrosine, strong

76 Tyrosine, weak

77 Xanthine, strong

78 Xanthine, weak

79 Xylan
Subgroup ...

\begin{tabular}{|c|c|c|c|c|c|c|}
\hline \multicolumn{5}{|c|}{ I } & \multicolumn{2}{|c|}{2} \\
\hline A & B & $\mathrm{C}$ & $\mathrm{D}$ & $\mathrm{E}$ & A & B \\
\hline I 8 & I I & 6 & 5 & 2 & 4 & 6 \\
\hline 0 & 0 & 0 & 0 & 0 & 100 & 100 \\
\hline 39 & 0 & 0 & 0 & 50 & 0 & 0 \\
\hline 100 & 100 & 67 & 100 & 100 & 100 & 0 \\
\hline
\end{tabular}

Hydrolysis tests

$\begin{array}{rrrrrrr}0 & 0 & 0 & 0 & 0 & 0 & 0 \\ 0 & 0 & 0 & 0 & 0 & 0 & 0 \\ 95 & 90 & 100 & 100 & 100 & 100 & 100 \\ 0 & 0 & 0 & 0 & 0 & 0 & 0 \\ 0 & 0 & 0 & 0 & 0 & 0 & 0 \\ 0 & 0 & 0 & 0 & 0 & 0 & 0 \\ 0 & 0 & 0 & 0 & 0 & 0 & 0 \\ 6 & 0 & 0 & 50 & 0 & 75 & 0 \\ 0 & 0 & 0 & 0 & 0 & 0 & 0 \\ 0 & 0 & 0 & 0 & 0 & 0 & 0 \\ 0 & 0 & 0 & 0 & 0 & 75 & 0 \\ 0 & 0 & 0 & 0 & 0 & 0 & 0 \\ 0 & 0 & 0 & 25 & 50 & 75 & 0 \\ 0 & 0 & 0 & 25 & 50 & 100 & 0 \\ 0 & 0 & 0 & 0 & 0 & 0 & 0 \\ 0 & 0 & 0 & 0 & 0 & 0 & 0 \\ 100 & 100 & 100 & 100 & 100 & 100 & 83 \\ 100 & 100 & 84 & 100 & 100 & 100 & 33 \\ 95 & 90 & 34 & 100 & 100 & 100 & 33 \\ 12 & 20 & 0 & 0 & 0 & 0 & 50 \\ 0 & 0 & 0 & 0 & 0 & 0 & 0 \\ 0 & 0 & 0 & 0 & 0 & 0 & 0 \\ 0 & 0 & 0 & 0 & 0 & 75 & 17 \\ 0 & 0 & 0 & 0 & 0 & 100 & 100 \\ 0 & 0 & 0 & 0 & 0 & 0 & 0\end{array}$

Sole carbon source

$\begin{aligned} 80 & \text { L-Arabinose } \\ 8 \text { I } & \text { D-Arabinose } \\ 82 & \text { D-Xylose } \\ 83 & \text { L-Rhamnose } \\ 84 & \text { D-Fructose } \\ 85 & \text { D-Galactose } \\ 86 & \text { D-Glucose } \\ 87 & \text { Mannose } \\ 88 & \text { Cellobiose } \\ 89 & \text { Lactose } \\ 90 & \text { Sucrose } \\ 91 & \text { Maltose } \\ 92 & \text { Trehalose } \\ 93 & \text { Melezitose } \\ 94 & \text { Raffinose } \\ 95 & \text { Glycogen } \\ 96 & \text { Inulin } \\ 97 & \text { Amygdalin } \\ 98 & \text { Arbutin } \\ 99 & \text { Salicin } \\ \text { 100 } & \text { Adonitol } \\ \text { I0I } & \text { Dulcitol } \\ \text { 102 } & \text { Glycerol }\end{aligned}$

$\begin{array}{rrrrrrr}0 & 0 & 0 & 0 & 0 & 0 & 0 \\ 0 & 0 & 0 & 0 & 0 & 0 & 0 \\ 0 & 0 & 0 & 0 & 0 & 0 & 0 \\ 61 & 30 & 17 & 50 & 50 & 0 & 0 \\ 95 & 80 & 100 & 75 & 100 & 100 & 100 \\ 28 & 30 & 0 & 50 & 0 & 0 & 0 \\ 100 & 100 & 100 & 100 & 100 & 75 & 100 \\ 90 & 60 & 100 & 100 & 100 & 100 & 0 \\ 0 & 0 & 0 & 0 & 0 & 75 & 0 \\ 0 & 0 & 0 & 0 & 0 & 0 & 0 \\ 12 & 0 & 0 & 0 & 0 & 25 & 17 \\ 61 & 90 & 100 & 50 & 50 & 0 & 100 \\ 39 & 10 & 0 & 50 & 0 & 0 & 67 \\ 0 & 0 & 0 & 0 & 0 & 0 & 0 \\ 0 & 0 & 0 & 0 & 0 & 0 & 0 \\ 0 & 0 & 0 & 0 & 0 & 0 & 0 \\ 0 & 0 & 0 & 0 & 0 & 0 & 0 \\ 12 & 0 & 0 & 0 & 0 & 0 & 0 \\ 0 & 0 & 0 & 0 & 0 & 0 & 60 \\ 12 & 20 & 0 & 0 & 0 & 20 & 0 \\ 0 & 0 & 0 & 0 & 0 & 0 & 0 \\ 0 & 0 & 0 & 0 & 0 & 0 & 0 \\ 78 & 80 & 17 & 100 & 100 & 100 & 100\end{array}$


Table I7 (cont.)

Cluster ...

Subgroup ...

No. of strains tested ...

103 Mannitol

I04 Sorbitol

I05 meso-Inositol

106 Dextrin

I07 Starch

108 Glucosamine

I09 Sodium acetate

I IO Sodium propionate

II I Sodium- $n$-butyrate

II 2 Sodium- $n$-octoate

I13 Sodium malonate

II4 Sodium benzoate

II5 Sodium succinate

II6 Adipic acid

117 Pimelic acid

II8 Sebacic acid

119 Sodium lactate

120 Sodium- $H$-malate

I2 I Sodium-D-tartrate

I22 Sodium citrate

I23 Sodium hippurate

$124 \mathrm{D}-\alpha$-Alanine

125 L- $\alpha$-Alanine

126 DL-nor-Leucine

127 L-Threonine

128 L-Serine

129 L-Tryptophan

I30 L-Proline

I3I L-Tyrosine

$132 p$-Hydroxybenzoic acid

$133 m$-Hydroxybenzoic acid

134 D-Mandelic acid

135 Protocatechuic acid

136 Testosterone

137 Sodium pyruvate

I38 Betaine $\mathrm{HCl}$

I39 Acetamide

I40 Benzamide

I4I $p$-Cresol

142 Paraffin

I43 Sodium gluconate

I44 $p$-Hydroxybenzaldehyde

\begin{tabular}{|c|c|c|c|c|c|c|}
\hline & & I & & & & \\
\hline A & B & $\mathrm{C}$ & $\mathrm{D}$ & $\mathrm{E}$ & A & B \\
\hline 18 & I I & 6 & 5 & 2 & 4 & 6 \\
\hline 67 & 30 & 50 & 50 & 50 & 84 & 100 \\
\hline 12 & 0 & 0 & 25 & 0 & 0 & I 7 \\
\hline 0 & 0 & 0 & 0 & 50 & 100 & 83 \\
\hline $6 I$ & 50 & 0 & 50 & 100 & 100 & 17 \\
\hline 67 & 20 & 17 & 25 & 50 & 50 & 67 \\
\hline 0 & 0 & 0 & 0 & 0 & 0 & 83 \\
\hline 100 & 100 & 100 & 100 & 100 & 100 & 100 \\
\hline 100 & 100 & 100 & 100 & 100 & 50 & IOO \\
\hline 100 & 100 & 100 & 100 & 100 & 100 & 100 \\
\hline 0 & 0 & 0 & 0 & 0 & 0 & 0 \\
\hline 0 & 0 & 0 & 0 & 0 & 0 & 0 \\
\hline 0 & 0 & 0 & 100 & 0 & 0 & 0 \\
\hline 95 & 90 & 100 & 100 & 100 & 100 & 100 \\
\hline 73 & 30 & 0 & 100 & 100 & 0 & 0 \\
\hline 0 & 0 & 0 & 0 & 0 & 0 & 0 \\
\hline 95 & 80 & 17 & 100 & 100 & 100 & 100 \\
\hline 0 & 0 & 0 & 0 & 0 & 0 & 0 \\
\hline 100 & 80 & 100 & 100 & IOO & 100 & 100 \\
\hline 0 & 0 & 0 & 0 & 0 & 0 & 0 \\
\hline 6 & 20 & 0 & 50 & 0 & 0 & 83 \\
\hline 0 & 0 & 0 & 0 & 0 & 0 & 0 \\
\hline 0 & 0 & 0 & 0 & 0 & 0 & 0 \\
\hline 0 & 0 & 0 & 0 & 0 & 0 & 60 \\
\hline 0 & 0 & 0 & 0 & 0 & 0 & 0 \\
\hline 0 & 0 & 0 & 0 & 0 & 0 & 0 \\
\hline 0 & 0 & 0 & 0 & 0 & 0 & 83 \\
\hline 0 & 0 & 0 & 0 & 0 & 0 & 0 \\
\hline 0 & 0 & 0 & 0 & 0 & 0 & 0 \\
\hline 0 & 0 & 0 & 0 & 0 & 0 & 0 \\
\hline 0 & 0 & 0 & 0 & 0 & 0 & 0 \\
\hline 22 & 10 & 0 & 0 & 50 & 0 & 0 \\
\hline 0 & 0 & 0 & 0 & 0 & 0 & 0 \\
\hline 12 & IO & 0 & 0 & 0 & 0 & 0 \\
\hline 84 & 60 & 67 & 25 & 100 & 100 & 100 \\
\hline 100 & 100 & 100 & 100 & 100 & 100 & 100 \\
\hline 0 & 0 & 0 & 0 & 0 & 0 & 0 \\
\hline 12 & 0 & 0 & 0 & 0 & 0 & 0 \\
\hline 0 & 0 & 0 & 0 & 0 & 0 & 0 \\
\hline 6 & 0 & 0 & 0 & 0 & 25 & 0 \\
\hline 100 & 100 & 100 & 100 & 100 & 75 & 100 \\
\hline 0 & 0 & 0 & 0 & 0 & 0 & 0 \\
\hline 0 & 0 & 0 & 0 & 0 & 25 & 0 \\
\hline
\end{tabular}

Sole carbon and nitrogen source

I45 Trimethyldiamine

I 46 Serine

I47 Acetamide

$\begin{array}{rr}0 & 0 \\ 0 & 0 \\ 17 & 0\end{array}$

Inhibition tests

Growth on YEA containing:

$\begin{array}{rrrrrrr}100 & 100 & 100 & 100 & 100 & 100 & 100 \\ 90 & 60 & 84 & 100 & 100 & 100 & 100 \\ 6 \mathrm{I} & 30 & 0 & 50 & 100 & 75 & 83 \\ 0 & 0 & 0 & 0 & 0 & 0 & 0 \\ 100 & 100 & 100 & 100 & 100 & 100 & 100\end{array}$


Table 17 (cont.)

Cluster $\quad \ldots$
Subgroup $\quad \ldots$

No. of strains tested ...

$1530.01 \%(\mathrm{w} / \mathrm{v})$ sodium azide

$154 \quad 0.02 \%(\mathrm{w} / \mathrm{v})$ sodium azide

$155 \quad 0.03 \%(\mathrm{w} / \mathrm{v})$ sodium azide

I $56 \quad 0.001 \%(\mathrm{w} / \mathrm{v})$ potassium tellurite

I $57 \quad 0.01 \%(\mathrm{w} / \mathrm{v})$ potassium tellurite

I $58 \quad 0.05 \%(\mathrm{w} / \mathrm{v})$ potassium tellurite

I $59 \quad 0 . \mathrm{I} \%(\mathrm{w} / \mathrm{V})$ potassium tellurite

$1600.1 \%(\mathrm{v} / \mathrm{v})$ phenyl ethanol

I6I $0.2 \%(\mathrm{v} / \mathrm{v})$ phenyl ethanol

$1620.3 \%(v / v)$ phenyl ethanol

I $630.4 \%(\mathrm{v} / \mathrm{V})$ phenyl ethanol

$1640.000001 \%(\mathrm{w} / \mathrm{v})$ crystal violet

$1650.00001 \%(\mathrm{w} / \mathrm{v})$ crystal violet

$166 \quad 0.0001 \%(\mathrm{w} / \mathrm{v})$ crystal violet

I $67 \quad 0.001 \%(\mathrm{w} / \mathrm{v})$ crystal violet

I $680.001 \%(\mathrm{v} / \mathrm{v})$ Teepol

I $690.005 \%(v / v)$ Teepol

$170 \quad 0.01 \%(\mathrm{v} / \mathrm{v})$ Teepol

I $7 \mathrm{I} \quad 0.001 \%(\mathrm{w} / \mathrm{v})$ phenol

$1720.01 \%(\mathrm{w} / \mathrm{v})$ phenol

$173 \quad 0.1 \%(w / v)$ phenol

$1740.0001 \%(\mathrm{w} / \mathrm{v})$ bismuth citrate

$1750.001 \%(\mathrm{w} / \mathrm{v})$ bismuth citrate

I $76 \quad 0.01 \%(\mathrm{w} / \mathrm{v})$ bismuth citrate

$177 \quad 0.0001 \%(\mathrm{w} / \mathrm{v})$ thallous acetate

$1780.001 \%(\mathrm{w} / \mathrm{v})$ thallous acetate

I79 $0.01 \%(w / v)$ thallous acetate

I $80 \quad 0.01 \%(\mathrm{w} / \mathrm{v})$ tetrazolium

I $81 \quad 0.01 \%(w / v)$ tetrazolium

I 82 Sensitivity to penicillin

Growth at:

I 83 pH 5

184 pH 6

$185 \mathrm{pH} 8$

$186 \quad \mathrm{pH}_{9}$

I $87 \quad \mathrm{pH}$ io

I $8850^{\circ}$

$18945^{\circ}$

$19040^{\circ}$

I9I $35^{\circ}$

$19210^{\circ}$

\begin{tabular}{|c|c|c|c|c|c|c|}
\hline \multicolumn{5}{|c|}{ I } & \multicolumn{2}{|c|}{2} \\
\hline A & B & $\mathrm{C}$ & D & $E$ & A & B \\
\hline 18 & I I & 6 & 5 & 2 & 4 & 6 \\
\hline 90 & 20 & 34 & 0 & 100 & 50 & 50 \\
\hline 22 & 0 & 0 & 0 & 0 & 0 & 0 \\
\hline 0 & 0 & 0 & 0 & 0 & 0 & 0 \\
\hline 100 & 100 & 84 & 100 & 100 & 100 & 100 \\
\hline 95 & 70 & 50 & 25 & 100 & 50 & 100 \\
\hline 90 & 40 & 67 & 0 & 100 & 83 & 50 \\
\hline 84 & 0 & 0 & 0 & 100 & 17 & 0 \\
\hline 90 & 70 & 100 & 100 & 100 & 100 & 100 \\
\hline 61 & 30 & 0 & 25 & 100 & 0 & 100 \\
\hline 39 & 0 & 0 & 0 & 50 & 0 & 87 \\
\hline 0 & 0 & 0 & 0 & 0 & 0 & 0 \\
\hline 100 & 100 & 100 & 100 & 100 & 100 & 100 \\
\hline 100 & 80 & 100 & 100 & 100 & 100 & 100 \\
\hline 45 & 40 & 50 & 25 & 0 & 25 & 67 \\
\hline 0 & 0 & 17 & 0 & 0 & 0 & 17 \\
\hline 100 & 100 & 100 & 50 & 100 & 100 & 100 \\
\hline 84 & 50 & 100 & 25 & 100 & 100 & 100 \\
\hline 84 & 20 & 100 & 50 & 100 & 0 & 100 \\
\hline 100 & 100 & 100 & 100 & 100 & 100 & 100 \\
\hline 100 & 60 & 100 & 75 & 100 & 100 & 83 \\
\hline 39 & 0 & 100 & 0 & 50 & 0 & 83 \\
\hline 95 & 90 & 100 & 100 & 100 & 100 & 100 \\
\hline 95 & 70 & 100 & 100 & 100 & 100 & 100 \\
\hline 73 & 20 & 0 & 50 & 50 & 75 & 100 \\
\hline 96 & 100 & 100 & 100 & 100 & 100 & 100 \\
\hline 6 & 0 & 0 & 0 & 0 & 0 & 33 \\
\hline 0 & 0 & 0 & 0 & 0 & 0 & 0 \\
\hline 67 & 10 & 34 & 50 & 100 & 50 & 100 \\
\hline 0 & 0 & 0 & 0 & 0 & 0 & 0 \\
\hline I 2 & 70 & 0 & 25 & 0 & 75 & 0 \\
\hline 6 & o & 0 & 0 & 0 & 0 & 0 \\
\hline 0 & o & 84 & 0 & 0 & 0 & 0 \\
\hline 100 & 100 & 100 & 100 & 100 & 100 & 100 \\
\hline 100 & 100 & 84 & 100 & 100 & 100 & 100 \\
\hline 84 & 30 & 83 & 25 & 100 & 100 & 100 \\
\hline 50 & 20 & 0 & 0 & 0 & 25 & 0 \\
\hline 90 & 40 & 67 & 25 & 100 & 25 & 83 \\
\hline 100 & 100 & 100 & 100 & 100 & 75 & 100 \\
\hline 100 & 100 & 100 & 100 & 100 & 100 & 100 \\
\hline I 2 & 60 & 0 & 50 & 0 & 75 & 0 \\
\hline
\end{tabular}

193 Benzidine, strong

Biochemical tests

I94 Benzidine, weak

195 Oxidase

196 Catalase

197 Nitrate reduction

I98 Urease, strong

I99 Urease, weak

200 Allantoinase, strong

201 Allantoinase, weak

202 Lysozyme-resistant

$203 p$-Nitrophenoloxidase

$204 m$-Nitrophenoloxidase

$\begin{array}{rrrrrrr}17 & 20 & 17 & 50 & 0 & 50 & 100 \\ 100 & 100 & 100 & 100 & 100 & 100 & 100 \\ 0 & 20 & 0 & 0 & 0 & 0 & 0 \\ 34 & 50 & 0 & 50 & 0 & 100 & 67 \\ 95 & 90 & 100 & 100 & 100 & 100 & 100 \\ 90 & 90 & 17 & 50 & 100 & 100 & 100 \\ 95 & 100 & 100 & 100 & 100 & 100 & 100 \\ 28 & 0 & 0 & 50 & 50 & 25 & 67 \\ 84 & 64 & 100 & 100 & 100 & 100 & 100 \\ 100 & 100 & 100 & 100 & 100 & 25 & 100 \\ 22 & 0 & 0 & 0 & 50 & 0 & 0 \\ 0 & 0 & 0 & 0 & 0 & 0 & 0\end{array}$


instance, strains of Nocardia asteroides and N. brasiliensis are separated by 17 unit characters. In the past $N$. madurae and $N$. pelletieri strains have been difficult to distinguish, especially if the $N$. pelletieri strains had lost their red pigment. In Table 15 these taxa are separated by I 2 species specific characters.

Except with highly atypical or intermediate strains it is neither practical nor necessary to carry out so many tests to achieve accurate identification. A practical diagnostic table was prepared which contained only I I characters (Table I6). These tests were selected because they gave conclusive results, were easy and quick to perform, and could be carried out even in laboratories with limited resources and equipment. These characters will usually be sufficient for the correct identification of nocardioform organisms which belong to one of the clusters. When necessary the identification of difficult strains can be strengthened by drawing upon additional characters from Table 15.

\section{Identification of subgroups}

The percentage frequency with which each character was positive in the subgroups of clusters I and 2, Nocardia asteroides and $N$. caviae respectively, is shown in Table I7. Although the strains in cluster I shared a large number of the properties, particularly negative ones, there were characters which could be used to differentiate the subgroups (Table 18 ). It is notable that the $N$. farcinica strains could be distinguished from the other subgroups not only by the characters shown in Table 17 but also by their slow growth rate and intense acid-fastness.

Table I8. Distinguishing characters for the subgroups of cluster I, the N. asteroides group

\begin{tabular}{|c|c|c|c|c|c|c|}
\hline Subs & roup $\ldots$ & A & $\mathrm{B}$ & $\mathrm{C}$ & $\mathrm{D}$ & $\mathrm{E}$ \\
\hline No. & f strains tested $\ldots$ & 18 & II & 6 & 5 & 2 \\
\hline II & Aerial hyphae, abundant & + & $d$ & - & + & $d$ \\
\hline I 2 & Colonies, white/grey & - & - & + & - & - \\
\hline 13 & Colonies, orange/pink/red & + & + & - & $d$ & + \\
\hline I 5 & Colonies, brown & - & - & - & + & - \\
\hline 17 & Exopigment, water-soluble & $d$ & $d$ & - & $d$ & $d$ \\
\hline 38 & Acid from maltose & $d$ & $d$ & $d$ & + & - \\
\hline 47 & Acid from adonitol & + & - & - & - & - \\
\hline I I 4 & Carbon source sodium benzoate & - & - & - & + & - \\
\hline I 16 & Carbon source adipic acid & $d$ & $d$ & - & + & + \\
\hline I I 8 & Carbon source sebacic acid & + & - & - & + & + \\
\hline 147 & Carbon and nitrogen source acetamide & - & - & - & - & + \\
\hline & Inhibition tests, growth on YEA contair & & & & & \\
\hline 150 & $7 \%(\mathrm{w} / \mathrm{v}) \mathrm{NaCl}$ & $d$ & $d$ & - & $d$ & + \\
\hline 153 & $0.01 \%(w / v)$ sodium azide & + & - & $d$ & - & + \\
\hline I 58 & $0.01 \%(w / v)$ potassium tellurite & + & - & - & - & + \\
\hline
\end{tabular}

The subgroups in cluster 2 could also be differentiated by a battery of characters. The Nocardia caviae strains form acid from trehalose, but not from mannose, use sodium citrate, glucosamine and L-serine as sole carbon sources and are not inhibited by $0.2 \%(\mathrm{v} / \mathrm{v})$ phenyl ethanol or $0 . \mathrm{I} \%(\mathrm{w} / \mathrm{v})$ phenol. Alternatively only the $N$. uniformis strains hydrolysed deoxyribonucleic acid, guanine and hypoxanthine.

The distribution of characters to the subgroups of the largest cluster, the Mycobacterium rhodochrous cluster, is shown in Table 19. The characters which have a presumptive diagnostic value for differentiating the subgroups are shown in Table 20. Several of these characters were used to construct a practical diagnostic table which can be used for identification of $M$. rhodochrous strains (Table 2I). 
Table 19. Percentage frequency of positive characters found in subgroups of cluster $\mathrm{I} 4$

$\begin{aligned} & \text { Subgroup ... } \\ & \text { No. of strains tested ... } \\ & \text { I } \text { Mycelium, formed } \\ & 2 \text { Mycelium, temporary } \\ & 3 \text { Rods and cocci found } \\ & 4 \text { Cocci only } \\ & 5 \text { Rods only } \\ & 6 \text { Acid-fastness, weak } \\ & 7 \text { Acid-fastness, strong } \\ & 8 \text { Strains motile } \\ & 9 \text { Aerial hyphae, sparse } \\ & \text { I0 } \text { Aerial hyphae, moderate } \\ & \text { II } \text { Aerial hyphae, abundant } \\ & \text { I2 } \text { Colonies, white/grey } \\ & \text { I3 } \text { Colonies, pink/orange/red } \\ & \text { I4 } \text { Colonies, black } \\ & \text { I5 } \text { Colonies, brown } \\ & \text { I6 } \text { Colonies, yellow } \\ & \text { I7 } \text { Exopigment, water soluble } \\ & \text { I8 } \text { Colony margin, entire } \\ & \text { I9 } \text { Colony margin, filamentous } \\ & 20 \text { Colony margin, deeply filamentous } \\ & 2 \text { I } \text { Colonies easy to emulsify } \\ & 22 \text { Suspension, coarse } \\ & 23 \text { Colony elevation, flat/raised } \\ & 24 \text { Colony elevation, convex } \\ & 25 \text { Colony elevation, irregular }\end{aligned}$

$\begin{array}{rrrrrrrr}\text { A } & \text { B } & \text { C } & \text { D } & \text { E } & \text { F } & \text { G } & \text { H } \\ 5 & 2 & 19 & 24 & \text { I3 } & 7 & 26 & 8 \\ 100 & 100 & 100 & 100 & 100 & 0 & 72 & 76 \\ 100 & 100 & 100 & 100 & 100 & 0 & 72 & 76 \\ 100 & 100 & 89 & 100 & 100 & 100 & 78 & 76 \\ 0 & 0 & 0 & 0 & 0 & 0 & 12 & 0 \\ 0 & 0 & 11 & 0 & 0 & 0 & 8 & 25 \\ 0 & 0 & 21 & 46 & 0 & 0 & 20 & 0 \\ 0 & 0 & 16 & 17 & 0 & 0 & 12 & 0 \\ 0 & 0 & 0 & 0 & 0 & 0 & 0 & 0 \\ 80 & 0 & 53 & 46 & 23 & 29 & 39 & 13 \\ 0 & 0 & 0 & 4 & 8 & 0 & 16 & 13 \\ 0 & 0 & 0 & 0 & 0 & 0 & 8 & 0 \\ 0 & 0 & 0 & 59 & 23 & 57 & 43 & 63 \\ 100 & 100 & 100 & 42 & 77 & 28 & 51 & 0 \\ 0 & 0 & 0 & 0 & 0 & 0 & 0 & 0 \\ 0 & 0 & 0 & 0 & 0 & 0 & 0 & 0 \\ 0 & 0 & 0 & 0 & 0 & 14 & 8 & 38 \\ 0 & 0 & 11 & 4 & 15 & 0 & 8 & 13 \\ 0 & 0 & 79 & 100 & 85 & 100 & 62 & 38 \\ 100 & 100 & 21 & 0 & 15 & 0 & 27 & 25 \\ 0 & 0 & 0 & 0 & 0 & 0 & 12 & 38 \\ 100 & 100 & 100 & 100 & 100 & 100 & 59 & 100 \\ 0 & 0 & 0 & 0 & 0 & 0 & 55 & 0 \\ 80 & 0 & 0 & 17 & 23 & 0 & 0 & 13 \\ 20 & 100 & 63 & 71 & 54 & 57 & 72 & 76 \\ 0 & 0 & 37 & 13 & 23 & 43 & 27 & 13\end{array}$

Acid from:

Fermentation studies

L-Arabinose
D-Arabinose
D-Xylose
L-Rhamnose
D-Fructose
D-Galactose
D-Glucose, oxidative
D-Glucose, fermentative
Mannose
Cellobiose
Lactose
Sucrose
Maltose
Trehalose
Melezitose
Raffinose
Glycogen
Inulin
Amygdalin
Arbutin
Salicin
Adonitol
Dulcitol
Glycerol
Mannitol
Sorbitol
meso-Inositol
Ethanol
Dextrin

$\begin{array}{rrrrrrrr}0 & 0 & 0 & 0 & 15 & 0 & 12 & 63 \\ 0 & 0 & 0 & 0 & 0 & 0 & 0 & 0 \\ 0 & 0 & 0 & 0 & 0 & 0 & 8 & 38 \\ 0 & 0 & 0 & 0 & 8 & 0 & 4 & 0 \\ 100 & 100 & 100 & 100 & 100 & 100 & 66 & 110 \\ 0 & 0 & 0 & 4 & 22 & 0 & 23 & 63 \\ 100 & 100 & 100 & 100 & 100 & 100 & 70 & 100 \\ 0 & 0 & 0 & 0 & 0 & 0 & 0 & 0 \\ 100 & 100 & 100 & 92 & 85 & 100 & 55 & 100 \\ 100 & 0 & 0 & 0 & 0 & 0 & 4 & 63 \\ 0 & 0 & 0 & 0 & 8 & 0 & 4 & 38 \\ 100 & 100 & 80 & 92 & 100 & 14 & 35 & 100 \\ 100 & 100 & 100 & 100 & 92 & 14 & 47 & 88 \\ 100 & 100 & 90 & 92 & 77 & 29 & 31 & 50 \\ 0 & 0 & 0 & 0 & 0 & 0 & 4 & 38 \\ 0 & 0 & 0 & 0 & 0 & 0 & 8 & 38 \\ 0 & 0 & 0 & 0 & 0 & 0 & 0 & 63 \\ 0 & 0 & 0 & 0 & 0 & 0 & 0 & 0 \\ 0 & 0 & 0 & 0 & 15 & 0 & 16 & 38 \\ 0 & 5 & 37 & 71 & 31 & 0 & 56 & 88 \\ 0 & 50 & 48 & 50 & 39 & 0 & 12 & 38 \\ 0 & 0 & 0 & 0 & 23 & 0 & 0 & 0 \\ 0 & 0 & 0 & 0 & 0 & 0 & 0 & 0 \\ 100 & 100 & 100 & 100 & 92 & 100 & 12 & 63 \\ 100 & 100 & 100 & 100 & 92 & 100 & 16 & 50 \\ 100 & 100 & 100 & 100 & 100 & 72 & 8 & 13 \\ 0 & 0 & 0 & 38 & 23 & 14 & 20 & 0 \\ 100 & 100 & 100 & 100 & 69 & 14 & 20 & 13 \\ 100 & 100 & 100 & 100 & 76 & 29 & 59 & 100\end{array}$


Table I9 (cont.)

Subgroup ...

No. of strains tested ...

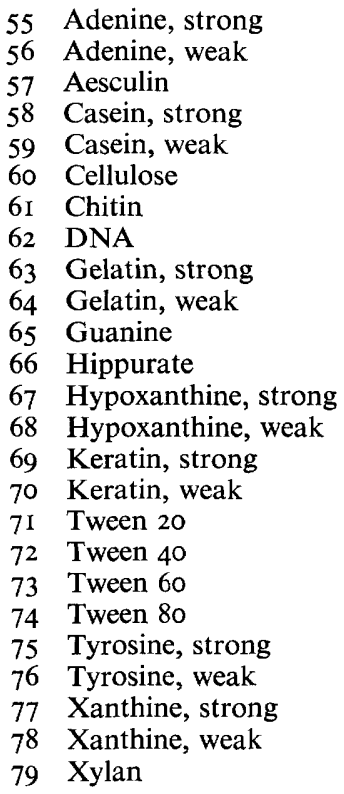

$$
\begin{array}{lllllllll}
\text { A } & \text { B } & \text { C } & \text { D } & \text { E } & \text { F } & \text { G } & \text { H }
\end{array}
$$

Hydrolysis tests

$\begin{array}{rrrrrrrr}0 & 0 & 53 & 67 & 54 & 0 & 16 & 0 \\ 100 & 100 & 69 & 71 & 62 & 0 & 20 & 0 \\ 100 & 100 & 95 & 100 & 92 & 100 & 84 & 88 \\ 0 & 0 & 0 & 0 & 8 & 15 & 8 & 100 \\ 0 & 0 & 0 & 0 & 8 & 57 & 8 & 100 \\ 0 & 0 & 0 & 0 & 0 & 0 & 0 & 0 \\ 0 & 0 & 0 & 0 & 0 & 0 & 0 & 0 \\ 0 & 100 & 42 & 92 & 69 & 86 & 50 & 88 \\ 0 & 0 & 0 & 0 & 0 & 86 & 16 & 63 \\ 0 & 0 & 0 & 0 & 0 & 86 & 39 & 100 \\ 0 & 0 & 0 & 0 & 23 & 100 & 4 & 0 \\ 0 & 0 & 5 & 0 & 0 & 0 & 0 & 0 \\ 0 & 0 & 0 & 0 & 8 & 14 & 0 & 0 \\ 0 & 0 & 0 & 0 & 8 & 14 & 4 & 0 \\ 0 & 0 & 0 & 0 & 0 & 0 & 0 & 25 \\ 0 & 0 & 0 & 0 & 0 & 0 & 13 & 38 \\ 100 & 100 & 100 & 100 & 100 & 100 & 90 & 100 \\ 100 & 100 & 100 & 100 & 100 & 100 & 74 & 100 \\ 100 & 100 & 100 & 100 & 100 & 100 & 74 & 76 \\ 100 & 0 & 21 & 4 & 0 & 0 & 8 & 13 \\ 100 & 50 & 100 & 38 & 46 & 57 & 16 & 0 \\ 100 & 50 & 100 & 59 & 46 & 72 & 16 & 0 \\ 0 & 0 & 0 & 0 & 8 & 14 & 0 & 0 \\ 0 & 0 & 0 & 0 & 8 & 14 & 4 & 0 \\ 0 & 0 & 0 & 0 & 0 & 0 & 0 & 0\end{array}$

Sole carbon source

\begin{aligned} 80 & L-Arabinose \\ 8 I & D-Arabinose \\ 82 & D-Xylose \\ 83 & L-Rhamnose \\ 84 & D-Fructose \\ 85 & D-Galactose \\ 86 & D-Glucose \\ 87 & Mannose \\ 88 & Cellobiose \\ 89 & Lactose \\ 90 & Sucrose \\ 91 & Maltose \\ 92 & Trehalose \\ 93 & Melezitose \\ 94 & Raffinose \\ 95 & Glycogen \\ 96 & Inulin \\ 97 & Amygdalin \\ 98 & Arbutin \\ 99 & Salicin \\ I00 & Adonitol \\ I01 & Dulcitol \\ 102 & Glycerol \\ I03 & Mannitol \\ I04 & Sorbitol \\ 105 & meso-Inositol \\ 106 & Dextrin \\ 107 & Starch \\ \hline & \end{aligned}


Subgroup ...

No. of strains tested ...

108 Glucosamine

109 Sodium acetate

IIO Sodium propionate

I I I Sodium- $n$-butyrate

112 Sodium-n-octoate

I13 Sodium malonate

II Sodium benzoate

115 Sodium succinate

116 Adipic acid

I 8 Sebacic acid

I 19 Sodium lactate

120 Sodium- $H$-malate

I I Sodium- $D$-tartrate

I22 Sodium citrate

123 Sodium hippurate

124 D- $\alpha$-Alanine

125 L- $\alpha$-Alanine

126 DL-nor-leucine

I27 L-Threonine

128 L-Serine

129 L-Tryptophan

130 L-Proline

I3 I L-Tyrosine

I32 $p$-Hydroxybenzoic acid

I33 $m$-Hydroxybenzoic acid

I34 D-Mandelic acid

135 Protocatechuic acid

136 Testosterone

137 Sodium pyruvate

138 Betaine $\mathrm{HCl}$

I39 Acetamide

I40 Benzamide

$141 \quad p$-Cresol

142 Paraffin

143 Sodium gluconate

I44 o-Hydroxybenzaldehyde
I17 Pimelic acid

Table 19 (cont.)

$\begin{array}{rrrrrrrr}\text { A } & \text { B } & \text { C } & \text { D } & \text { E } & \text { F } & \text { G } & \text { H } \\ 5 & 2 & 19 & 24 & \text { I3 } & 7 & 26 & 8 \\ 0 & 0 & 48 & 84 & 54 & 0 & 4 & 90 \\ 0 & 100 & 100 & 92 & 92 & 72 & 46 & 100 \\ 100 & 100 & 100 & 100 & 100 & 100 & 74 & 38 \\ 100 & 100 & 100 & 92 & 100 & 100 & 60 & 4 \\ 100 & 0 & 80 & 34 & 23 & 0 & 23 & 0 \\ 0 & 0 & 0 & 0 & 0 & 0 & 0 & 0 \\ 0 & 50 & 80 & 13 & 23 & 100 & 0 & 0 \\ 100 & 100 & 95 & 100 & 85 & 72 & 23 & 0 \\ 100 & 50 & 100 & 88 & 70 & 0 & 12 & 0 \\ 0 & 50 & 100 & 63 & 46 & 14 & 8 & 0 \\ 0 & 100 & 100 & 92 & 62 & 0 & 20 & 0 \\ 100 & 100 & 100 & 88 & 39 & 0 & 8 & 38 \\ 0 & 100 & 100 & 100 & 92 & 86 & 35 & 50 \\ 100 & 0 & 0 & 4 & 15 & 14 & 0 & 13 \\ 100 & 100 & 100 & 88 & 77 & 100 & 16 & 38 \\ 0 & 0 & 0 & 0 & 8 & 0 & 4 & 0 \\ 0 & 100 & 64 & 59 & 85 & 0 & 12 & 13 \\ 0 & 100 & 16 & 92 & 85 & 0 & 27 & 13 \\ 100 & 50 & 90 & 42 & 39 & 0 & 0 & 0 \\ 0 & 0 & 0 & 8 & 31 & 14 & 4 & 13 \\ 0 & 50 & 5 & 59 & 70 & 14 & 8 & 0 \\ 0 & 0 & 0 & 0 & 0 & 0 & 0 & 0 \\ 0 & 50 & 48 & 50 & 46 & 0 & 16 & 13 \\ 100 & 50 & 100 & 17 & 23 & 0 & 0 & 13 \\ 0 & 100 & 80 & 92 & 39 & 0 & 4 & 0 \\ 100 & 100 & 80 & 4 & 8 & 0 & 35 & 0 \\ 0 & 0 & 0 & 0 & 0 & 0 & 4 & 0 \\ 100 & 100 & 100 & 84 & 62 & 28 & 20 & 25 \\ 100 & 0 & 100 & 96 & 69 & 0 & 23 & 0 \\ 100 & 100 & 100 & 100 & 100 & 100 & 59 & 38 \\ 0 & 0 & 0 & 0 & 0 & 0 & 8 & 0 \\ 100 & 100 & 95 & 88 & 77 & 29 & 4 & 25 \\ 100 & 0 & 16 & 0 & 0 & 0 & 0 & 0 \\ 100 & 100 & 100 & 29 & 0 & 0 & 4 & 0 \\ 100 & 100 & 100 & 96 & 92 & 100 & 59 & 76 \\ 0 & 100 & 80 & 96 & 92 & 43 & 23 & 76 \\ 100 & 50 & 37 & 21 & 39 & 0 & 4 & 0 \\ & & & & & & & \end{array}$

Sole carbon and nitrogen source

145 Trimethyldiamine

I46 Serine

147 Acetamide

Growth on YEA containing:

Inhibition tests

I $48 \quad 3 \%(w / v) ~ N a C l$

I $495 \%(w / v) ~ N a C l$

I $50 \quad 7 \%(w / v) ~ N a C l$

I 5 I $10 \%(\mathrm{w} / \mathrm{v}) \mathrm{NaCl}$

I $52 \quad 0.001 \%(\mathrm{w} / \mathrm{v})$ sodium azide

I $53 \quad 0.01 \%(\mathrm{w} / \mathrm{v})$ sodium azide

I $54 \quad 0.02 \%(w / v)$ sodium azide

$155 \quad 0.03 \%(\mathrm{w} / \mathrm{v})$ sodium azide

I $56 \quad 0.001 \%(\mathrm{w} / \mathrm{v})$ potassium tellurite

I $57 \quad 0.01 \%(\mathrm{w} / \mathrm{v})$ potassium tellurite

I $58 \quad 0.05 \%(\mathrm{w} / \mathrm{v})$ potassium tellurite

I 59 $0.1 \%(\mathrm{w} / \mathrm{v})$ potassium tellurite

160

$\begin{array}{rrrrrrrr}100 & 100 & 100 & 100 & 100 & 100 & 78 & 100 \\ 100 & 0 & 100 & 92 & 100 & 100 & 50 & 88 \\ 100 & 0 & 85 & 80 & 85 & 86 & 47 & 50 \\ 80 & 0 & 5 & 0 & 15 & 57 & 4 & 13 \\ 100 & 100 & 100 & 100 & 100 & 100 & 100 & 100 \\ 0 & 0 & 80 & 100 & 85 & 43 & 39 & 76 \\ 0 & 0 & 42 & 84 & 77 & 14 & 20 & 38 \\ 0 & 0 & 5 & 71 & 39 & 14 & 8 & 25 \\ 100 & 100 & 100 & 100 & 100 & 100 & 82 & 100 \\ 100 & 100 & 100 & 84 & 100 & 100 & 70 & 88 \\ 100 & 0 & 100 & 63 & 92 & 57 & 31 & 25 \\ 100 & 0 & 74 & 8 & 77 & 29 & 28 & 0 \\ 100 & 100 & 100 & 100 & 100 & 100 & 96 & 100\end{array}$


Table I9 (cont.)

\begin{tabular}{|c|c|}
\hline Subg & up $\quad \ldots$ \\
\hline No. & strains tested \\
\hline I $6 \mathrm{I}$ & $0.2 \%(\mathrm{v} / \mathrm{v})$ phenyl ethanol \\
\hline 162 & $0.3 \%(\mathrm{v} / \mathrm{v})$ phenyl ethanol \\
\hline 163 & $0.4 \%(v / v)$ phenyl ethanol \\
\hline 164 & $0.000001 \%(w / v)$ crystal violet \\
\hline 165 & $0.0000 \mathrm{I} \%(\mathrm{w} / \mathrm{v})$ crystal violet \\
\hline 166 & $0.0001 \%(\mathrm{w} / \mathrm{v})$ crystal violet \\
\hline 167 & $0.001 \%(w / v)$ crystal violet \\
\hline 168 & $0.001 \%(v / v)$ Teepol \\
\hline 169 & $0.005 \%(v / v)$ Teepol \\
\hline 170 & $0.01 \%(\mathrm{v} / \mathrm{v})$ Teepol \\
\hline 171 & $0.001 \%(w / v)$ phenol \\
\hline 172 & $0.01 \%(w / v)$ phenol \\
\hline 173 & $0.1 \%(\mathrm{w} / \mathrm{v})$ phenol \\
\hline 174 & $0.0001 \%(\mathrm{w} / \mathrm{v})$ bismuth citrate \\
\hline 175 & $0.001 \%(\mathrm{w} / \mathrm{v})$ bismuth citrate \\
\hline 176 & $0.01 \%(w / v)$ bismuth citrate \\
\hline 177 & $0.0001 \%(\mathrm{w} / \mathrm{v})$ thallous acetate \\
\hline 178 & $0.001 \%(\mathrm{w} / \mathrm{v})$ thallous acetate \\
\hline 179 & $0.01 \%(w / v)$ thallous acetate \\
\hline 180 & $0.01 \%(w / v)$ tetrazolium \\
\hline I $8 I$ & $0 \cdot I \%(w / v)$ tetrazolium \\
\hline 182 & Sensitivity to penicillin \\
\hline & rowth at: \\
\hline 183 & $\mathrm{pH} 5$ \\
\hline I 84 & $\mathrm{pH} 6$ \\
\hline 185 & $\mathrm{pH} 8$ \\
\hline 186 & $\mathrm{pH} 9$ \\
\hline 187 & $\mathrm{pH}$ \\
\hline 188 & $50^{\circ}$ \\
\hline 189 & $45^{\circ}$ \\
\hline 190 & $40^{\circ}$ \\
\hline I9I & $35^{\circ}$ \\
\hline 192 & $10^{\circ}$ \\
\hline
\end{tabular}

$\begin{array}{rrrrrrrr}\text { A } & \text { B } & \text { C } & \text { D } & \text { E } & \text { F } & \text { G } & \text { H } \\ 5 & 2 & 19 & 24 & 13 & 7 & 26 & 8 \\ 100 & 100 & 100 & 100 & 100 & 86 & 62 & 100 \\ 100 & 0 & 100 & 96 & 85 & 29 & 47 & 88 \\ 0 & 0 & \text { I } & 58 & 31 & 0 & 35 & 25 \\ 100 & 100 & 100 & 100 & 100 & 100 & 66 & 100 \\ 100 & 100 & 100 & 100 & 100 & 100 & 55 & 100 \\ 100 & 50 & 80 & 46 & 54 & 57 & 23 & 25 \\ 0 & 0 & 42 & 0 & 15 & 0 & 8 & 0 \\ 100 & 100 & 100 & 100 & 100 & 100 & 100 & 100 \\ 100 & 100 & 100 & 100 & 100 & 100 & 62 & 88 \\ 100 & 100 & 90 & 100 & 100 & 14 & 43 & 88 \\ 100 & 100 & 100 & 100 & 100 & 100 & 100 & 100 \\ 100 & 100 & 100 & 100 & 100 & 57 & 59 & 100 \\ 100 & 100 & 80 & 55 & 46 & 0 & 8 & 63 \\ 100 & 100 & 100 & 100 & 100 & 100 & 82 & 100 \\ 100 & 100 & 100 & 100 & 100 & 57 & 50 & 88 \\ 100 & 100 & 58 & 29 & 62 & 0 & 8 & 76 \\ 100 & 100 & 100 & 100 & 100 & 100 & 66 & 100 \\ 0 & 50 & 16 & 4 & 15 & 100 & 16 & 38 \\ 0 & 0 & 0 & 0 & 0 & 0 & 8 & 0 \\ 100 & 100 & 100 & 100 & 92 & 100 & 82 & 100 \\ 0 & 0 & 0 & 0 & 0 & 0 & 4 & 13 \\ 100 & 100 & 100 & 100 & 100 & 100 & 78 & 88\end{array}$

$\begin{array}{rrrrrrrr}0 & 0 & 0 & 8 & 0 & 0 & 0 & 0 \\ 100 & 100 & 100 & 100 & 100 & 100 & 86 & 76 \\ 100 & 100 & 100 & 100 & 100 & 100 & 86 & 88 \\ 100 & 100 & 100 & 84 & 92 & 100 & 62 & 76 \\ 100 & 100 & 100 & 84 & 62 & 86 & 39 & 38 \\ 0 & 0 & 0 & 4 & 0 & 0 & 0 & 0 \\ 0 & 0 & 11 & 4 & 8 & 0 & 20 & 0 \\ 100 & 50 & 100 & 92 & 92 & 0 & 62 & 63 \\ 100 & 100 & 100 & 96 & 100 & 100 & 66 & 88 \\ 100 & 100 & 100 & 84 & 92 & 100 & 22 & 76\end{array}$

Biochemical tests

$\begin{array}{ll}193 & \text { Benzidine, strong } \\ 194 & \text { Benzidine, weak } \\ 195 & \text { Oxidase } \\ 196 & \text { Catalase } \\ 197 & \text { Nitrate reduction } \\ 198 & \text { Urease, strong } \\ 199 & \text { Urease, weak } \\ 200 & \text { Allantoinase, strong } \\ 201 & \text { Allantoinase, weak } \\ 202 & \text { Lysozyme resistant } \\ 203 & p \text {-Nitrophenoloxidase } \\ 204 & m \text {-Nitrophenoloxidase }\end{array}$

$\begin{array}{rrrrrrrr}100 & 100 & 100 & 100 & 100 & 100 & 100 & 25 \\ 100 & 100 & 100 & 100 & 100 & 100 & 100 & 100 \\ 20 & 0 & 0 & 0 & 0 & 29 & 4 & 0 \\ 100 & 100 & 100 & 100 & 77 & 86 & 59 & 25 \\ 100 & 100 & 100 & 88 & 92 & 86 & 70 & 88 \\ 0 & 50 & 0 & 84 & 85 & 14 & 39 & 25 \\ 0 & 100 & 0 & 84 & 92 & 14 & 59 & 25 \\ 0 & 0 & 0 & 4 & 23 & 14 & 8 & 0 \\ 0 & 100 & 0 & 59 & 85 & 14 & 27 & 25 \\ 0 & 0 & 0 & 0 & 0 & 0 & 12 & 0 \\ 100 & 0 & 0 & 0 & 8 & 14 & 0 & 0 \\ 0 & 50 & 42 & 4 & 0 & 0 & 0 & 0\end{array}$

\section{CONCLUSIONS}

The test strains were recovered in a few defined clusters. Jones \& Bradley (I964) and Cerbón (1967) in their numerical taxonomic studies did not obtain well-defined groups, although this was probably due to inadequate strain selection. Tsukamura (1969) examined more strains, which clustered well, but many of the unit characters he used were ineffective for differentiating nocardiae, and recent studies by P. V. Kurup \& J. A. Schmitt (personal 
Table 20. Distinguishing characters for the subgroups of cluster 14, the Mycobacterium rhodochrous group

\begin{tabular}{|c|c|c|c|c|c|c|c|c|c|}
\hline Subgro & & A & B & $\mathrm{C}$ & D & $\mathrm{E}$ & $\mathbf{F}$ & G & $\mathrm{H}$ \\
\hline No. of & strains tested $\ldots$ & 5 & 2 & 19 & 24 & 13 & 7 & 26 & 8 \\
\hline I & Mycelium, formed & + & + & + & + & + & - & $d$ & $d$ \\
\hline 13 & Colonies, pink/orange/red & + & + & + & $d$ & + & $d$ & $d$ & - \\
\hline 19 & Colony margin, filamentous & + & + & - & - & - & - & $d$ & $d$ \\
\hline & Acid from: & & & & & & & & \\
\hline 35 & Cellobiose & + & - & - & - & - & - & - & $d$ \\
\hline 37 & Sucrose & + & + & + & + & + & - & $d$ & + \\
\hline 49 & Glycerol & + & + & + & + & + & + & - & $d$ \\
\hline $5 \mathrm{I}$ & Sorbitol & + & + & + & + & + & $d$ & - & - \\
\hline & Hydrolysis of: & & & & & & & & \\
\hline 56 & Adenine, weak & + & + & $d$ & $d$ & $d$ & - & - & - \\
\hline 58 & Casein, strong & - & - & - & - & - & - & - & + \\
\hline 62 & DNA. & - & + & $d$ & + & $d$ & + & $d$ & + \\
\hline 65 & Guanine & - & - & - & - & $d$ & + & - & - \\
\hline 74 & Tween 80 & + & - & - & - & - & - & - & - \\
\hline 75 & Tyrosine, strong & + & $d$ & + & $d$ & $d$ & $d$ & - & - \\
\hline & Sole carbon source: & & & & & & & & \\
\hline 108 & Glucosamine & - & - & $d$ & + & $d$ & - & - & - \\
\hline 109 & Sodium acetate & - & + & + & + & + & $d$ & $d$ & + \\
\hline II 2 & Sodium- $n$-octoate & + & - & + & $d$ & $d$ & - & $d$ & - \\
\hline II 4 & Sodium benzoate & - & $d$ & + & - & $d$ & + & - & - \\
\hline 116 & Adipic acid & + & $d$ & + & + & $d$ & - & - & - \\
\hline 117 & Pimelic acid & - & $d$ & + & $d$ & $d$ & - & - & - \\
\hline 118 & Sebacic acid & - & + & + & + & $d$ & - & - & - \\
\hline 119 & Sodium lactate & - & + & + & + & $d$ & - & - & $d$ \\
\hline 120 & Sodium- $H$-malate & - & + & + & + & + & + & $d$ & $d$ \\
\hline I2I & Sodium- $D$-tartrate & - & - & - & - & - & - & - & - \\
\hline 125 & L- $\alpha$-Alanine & - & + & - & + & + & - & $d$ & - \\
\hline I 26 & DL-nor-Leucine & + & $d$ & + & $d$ & $d$ & - & - & - \\
\hline I3I & L-Tyrosine & + & $d$ & + & - & $d$ & - & - & - \\
\hline 132 & $p$-Hydroxybenzoic acid & - & + & + & + & $d$ & - & - & - \\
\hline I33 & $m$-Hydroxybenzoic acid & + & + & + & - & - & - & $d$ & - \\
\hline 136 & Testosterone & + & - & + & + & $d$ & - & $d$ & - \\
\hline 140 & Benzamide & + & - & - & - & - & - & - & - \\
\hline I4I & $p$-Cresol & + & + & + & $d$ & - & - & - & - \\
\hline I44 & $o$-Hydroxybenzaldehyde & + & $d$ & $d$ & - & $d$ & - & - & - \\
\hline & Inhibited by: & & & & & & & & \\
\hline 150 & $7 \%(w / v) \mathrm{NaCl}$ & + & - & + & + & + & + & $d$ & $d$ \\
\hline I53 & $0.01 \%(w / v)$ sodium azide & - & - & + & + & + & $d$ & $d$ & $d$ \\
\hline 162 & $0.3 \%$ (v/v) phenyl ethanol & + & - & + & + & + & $d$ & $d$ & + \\
\hline & Biochemical tests & & & & & & & & \\
\hline 199 & Urease, weak & - & + & - & + & + & - & $d$ & su \\
\hline 201 & Allantoinase, weak & - & + & - & $d$ & + & - & $d$ & $d$ \\
\hline 203 & $p$-Nitrophenoloxidase & + & - & - & - & - & - & - & \\
\hline
\end{tabular}

communication, 197I) have included only the strongly mycelial or 'hard' growing nocardiae. The distribution of nocardioform bacteria to 15 distinct clusters was, therefore, encouraging.

The five well-known pathogenic species of Nocardia were recovered in and characterize five of the major clusters. Cluster I contained Nocardia asteroides strains and cultures bearing nine specific names already reduced to synonyms of that species (Gordon \& Mihm, I957, I959 $a, 1962 b$ ). With the exception of $N$. farcinica these nomenspecies are undoubtably 
Table 21. Diagnostic table for the identification for the subgroups of cluster I4, the Mycobacterium rhodochrous group

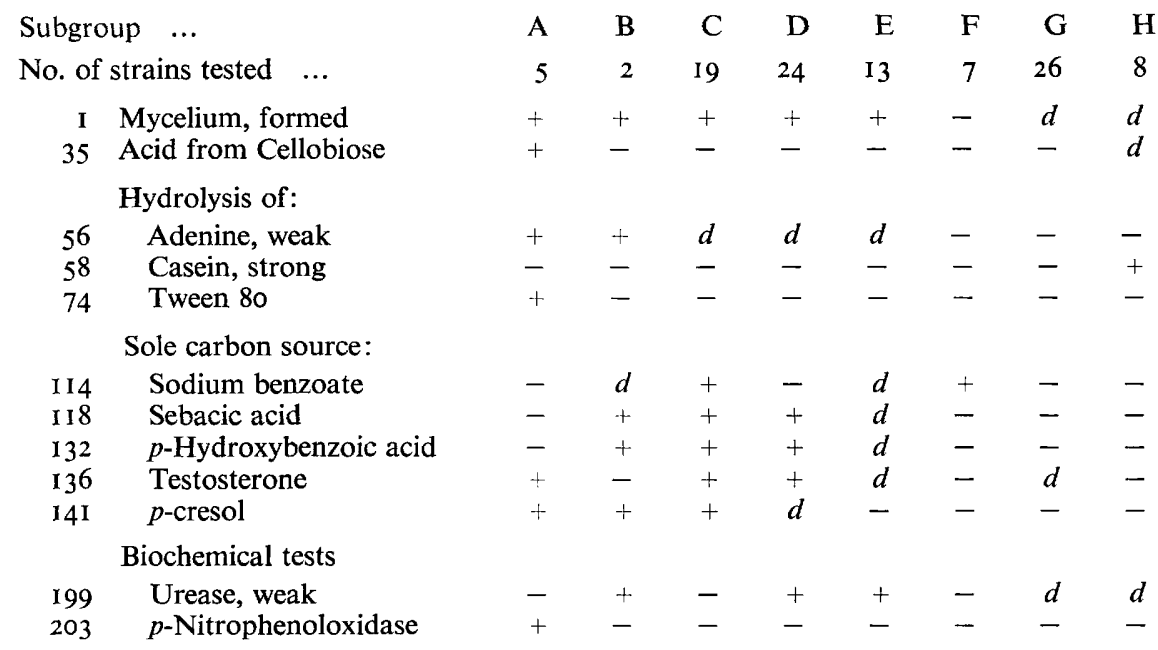

historical legacies based upon a few strains which were inadequately characterized. The strains in the $N$. asteroides cluster exhibited a common set of characters but also showed a high degree of variability under the test conditions. Nocardia asteroides was also found to be heterogeneous in work based upon morphological and biochemical criteria (Georg, Ajello, McDurmont \& Hosty, I96I ; Cerbón, I967), on physiological characters (Mariat, 1965), and on serological properties (Kwapinski, 1970; Pier \& Fichtner, 197I). P. V. Kurup \& J. A. Schmitt (personal communication, I97I) divided $N$. asteroides into four subgroups, whereas Tsukamura (I969) divided it into two major clusters one of which he designated $N$. farcinica. The results of the present study confirm that $N$. asteroides can be divided into homogeneous subgroups which can be defined and identified by characters extracted from the data. Further work is required to throw more light on the taxonomic status of these subgroups.

Subgroup I $\mathrm{C}$ is of particular interest for it contains the type species of the genus, including what may be the original type strain, Nocardia farcinica, ATCC 3318. The other strains in this subgroup were isolated from cases of bovine farcy in West Africa. Gordon \& Mihm (1962 $b$ ) considered $N$. farcinica to be a synonym of $N$. asteroides, but Mariat (1963) and Magnusson \& Mariat (I968) considered that $N$. farcinica should be given independent specific status. The present results and those of Tsukamura (1969) confirm that $N$. farcinica strains fall into a group which can be separated from those containing $N$. asteroides strains. Subgroup I C could not, however, be directly equated with Tsukamura's $N$. farcinica cluster. The respective groups did contain strain ATCC 33 I 8 , but several bacteria considered to be $N$. farcinica by Tsukamura (I969) were found in subgroups I A and I C. Tsukamura (1969) did not study any of the slow-growing, strongly acid-fast $N$. farcinica from West Africa, bacteria which have been considered to be mycobacteria because they contain mycolic acids (Chamoiseau \& Asselineau, 1970; Lechevalier et al. 197I). It seems probable that $N$. farcinica strains from West Africa are different from other strains bearing this name. If so it is puzzling that strain ATCC 3318, allegedly Nocard's original isolate, shares such a high general similarity with the slow growing $N$. farcinica strains from West Africa. It may be that in this case cluster formation has been influenced by factors such as growth rate. Recently Sneath (1968) has described a method of calculating phenetic similarities which takes into account differences which can be 
explained by factors such as the unequal growth rates of strains. This programme will be applied to the test data and the results will show whether cluster formation in subgroup I C has been affected by growth rate.

The Nocardia caviae and N. brasiliensis strains fell into tight clusters, a result which is in good agreement with those of Tsukamura (1969). The distinction between each of these species, and between them and $N$. asteroides, is maintained. Additional work is required to see whether $N$. uniformis should be considered as a synonym of $N$. caviae or whether it forms a distinct group lying between $N$. caviae and $N$. asteroides. The $N$. asteroides, $N$. caviae and $N$. brasiliensis clusters unite to form an aggregate group, sharply differentiated from the other major clusters at the $75 \% \mathrm{~S}$-level. These three species, therefore, share a high phenetic similarity, have a wall composition of type IV (Lechevalier, Lechevalier \& Becker, 1966), contain a characteristic lipid (Mordarska \& Mordarski, I969) and have strong serological affinities (Kwapinski, 1970). The three clusters form the core of the genus Nocardia, and $N$. caviae and $N$. brasiliensis can be considered to be taxospecies.

The Nocardia madurae and N. pelletieri strains are found in two major clusters which join the nocardia clusters only at a low level of similarity. These species have been transferred to the genus Streptomyces (Mackinnon \& Artagaveytia-Allende, I956; Mariat, 1958, 1962) but Gordon (1966a) retained them as Nocardia. Nocardia pelletieri and N. madurae strains can be separated from $N$. asteroides, $N$. caviae and $N$. brasiliensis on the phenetic evidence, serologically (Kwapinski, 1970), and they have a wall composition of type III (Lechevalier et al. 1966) They share a low phenetic similarity with Streptomyces spp. which have a wall composition of type I (Lechevalier et al. 1966). The results of the numerical taxonomic study therefore lend strong support to the proposal that $N$. madurae and $N$. pelletieri be placed in the new genus Actinomadura (Lechevalier \& Lechevalier, 1970). This genus was defined exclusively on morphological and chemotaxonomic evidence and many of these characters are difficult to detect. In the present work it was possible to distinguish the $N$. madurae and $N$. pelletieri clusters from one another, and from the other nocardioform clusters by a battery of repeatable characters which were easy to observe.

The phenetic similarity between Actinomadura madurae and $A$. pelletieri is not high. Since $A$. pelletieri strains grew very slowly the low similarity may be a function of growth rates and not be due to a large difference in the properties of the two species. The application of the vigour and pattern programme (Sneath, 1968) will show whether this is so. It is interesting to find that the $A$. madurae cluster is heterogeneous. Further taxonomic work is needed on A.madurae strains; perhaps strains from different habitats fall into distinct groups. Lechevalier \& Lechevalier (1970) included Nocardia dassonvillei in the genus Actinomadura. This proposal cannot be strongly supported by the present results because the $N$. dassonvillei cluster is sharply separated from all the other clusters although it is true that the highest similarity shown by the $N$. dassonvillei strains is with $A$. madurae strains.

The Nocardia turbata strains share a high phenetic similarity and are quite distinct from the other clusters. Sukapure et al. (1970) found that turbata strains did not fit into any previously described genera. Their inclusion in the new genus Oerskovia (Prauser et al. 1970) is strongly supported.

In my preliminary studies Mycobacterium rhodochrous strains formed a distinct cluster readily delineated from other clusters containing nocardioform bacteria. The $M$. rhodochrous cluster is recovered in this enlarged study and contains strains carrying over 30 specific names. Gordon \& Mihm (I959b, I96I) and Gordon (I966b) also found that the alleged differences between species of 'soft' growing nocardioform strains were tenuous and reduced many of the names to synonyms of $M$. rhodochrous. Additional species continue to be identi- 
fiable with $M$. rhodochrous (Mitchell \& Shewan, 1968) and Nocardia pellegrino can now be added to them. Castelnuova, Bellezza, Duncan \& Asselineau (1964) and Juhasz \& Bönicke ( I965) also placed $N$. pellegrino strains into the same group as Nocardia corallina, N. rubra and certain $M$.rhodochrous strains. The $M$.rhodochrouscluster is heterogeneous and can be divided into subgroups which can be defined and identified by a group of characters. There is no reliable way of equating clusters or subgroups with orthodox taxonomic ranks. Numerical taxonomists generally adjust the level of similarity to meet their own concept of species. Further work is required to find out whether the homogeneous subgroups - I4 A which contains $N$. pellegrino, ${ }_{4} 4 \mathrm{C}$ which includes $N$. corrallina, $N$. rubra and $N$. salmonicolor, I4D which includes $N$. erythropolis, $N$. rubropertincta and Jensenia canicruria, and I4F which contains arthrobacter and corynebacteria strains - can be equated with taxospecies or biotypes. In this context it is interesting that Adams, Adams \& Brownell (1970) considered $J$. canicruria to be a synonym of $N$. erythropolis but different from $M$. rhodochrous strains.

Although the Mycobacterium rhodochrous group constitutes a recognizable taxonomic entity its generic location is still unsettled. Mycobacterium rhodochrous strains show a closer phenetic relationship with Nocardia asteroides, $N$. caviae and $N$. brasiliensis than with strains of Runyon's group IV mycobacteria. Recently Lechevalier et al. (I97I) have found that $M$. rhodochrous strains contain nocardomycolic acids but the fast growing mycobacteria show the presence of mycolic acids. It would appear that the $M$. rhodochrous group shows a greater taxonomic affinity to Norcardia than to Mycobacterium and could be provisionally placed in the genus Nocardia. Further work is needed to see if the rhodochrovs group deserves recognition as a genus, and to establish the relationship of the taxon with diphtheroid bacteria, particularly arthrobacter.

The taxonomic status of the minor clusters and of the unclustered strains is not clear. Some of these bacteria may be nuclei around which future species of Nocardia will cluster, others are strains which are misplaced in the genus. The former include the minor clusters containing Nocardia gardneri and $N$. vaccinii, and the strains of $N$. hydrocarboxydans, $N$. narashinoensis and $N$. petroleophila. Alternatively the $N$. formica, $N$. italica and $S$. somaliensis strains are phenetically distinct, contain major amounts of L-2,6-diaminopimelic acid, and should be placed in the genus Streptomyces. The taxonomic position of strains such as N. coeliaca, N. lurida, N. rugosa, N. saturnea and Cellulomonas biazotea is still confused.

One of the advantages of numerical taxonomy is that the clusters which are defined have a high information content. Each cluster can be examined for discriminating features that can be weighted for identification. In the present study it was possible to construct a diagnostic table for the identification of the main clusters of nocardioform bacteria. In the case of the Nocardia asteroides and Mycobacterium rhodochrous clusters tables were devised for the identification of the subgroups. Several features are needed to define each cluster or subgroup, so that no one character is either sufficient or necessary to identify an isolate. The clusters are therefore operationally polythetic and can accommodate a degree of strain variability thereby reducing the chances of variants of a species being defined as new species. Classical tests such as acid-fastness, pigmentation and paraffin utilization were found not to have a high differentiating power, a result which emphasizes the danger of creating taxa on the basis of a few subjectively chosen characters. Alternatively some of the tests which had not been performed before did have a high diagnostic value. They include the utilization of some of the carbon compounds as sole sources of carbon and energy, and keratin and deoxyribonucleic acid hydrolysis. Although many of the carbon compounds did not support growth their failure to do so is open to several interpretations, such as complexing of the compounds in the medium or because the strains were sensitive to the toxic effects of the 
compounds at the concentrations used, or because the bacteria were unable to synthesize the enzymes necessary for metabolizing the compounds. It was noted that the results of some of the tests did not agree with those obtained by Tsukamura (1969). Now that significant groups of nocardioform bacteria have been obtained the search for additional simple reproducible phenotypic characters which can be weighted for identification can be intensified.

In conclusion, it can be said that the results confirm that the earlier taxonomy of the nocardioform bacteria was illogical. They also show that most of the nocardioform bacteria fall into one or other of several large recognizable groups and it is hoped that additional isolates will be allocated to the correct group by using the relevant diagnostic table. It should be stressed, however, that the results of this study, which are useful and many, represent only a first step towards characterizing the phenotypes of nocardioform bacteria. Future studies can, for the first time, be carried out on strains which have a recognized taxonomic identity. The genus Nocardia can no longer be considered a taxon of convenience.

I thank Professor P. H. A. Sneath for his keen interest in and warm encouragement of this work. I am indebted to Mr M. Sackin for his invaluable help with the computation and also to the many scientists who generously contributed strains.

The Medical Research Council kindly awarded me a Research Studentship tenable at the M.R.C. Microbial Systematics Unit, Leicester University, where most of this work was done.

\section{REFERENCES}

Adams, M. M., Adams, J. N. \& Brownell, G. H. ( I970). The identification of Jensenia canicruria Bisset and Moore as a mating type of Nocardia erythropolis (Gray and Thornton) Waksman and Henrici. International Journal of Systematic Bacteriology 20, I33-147.

Bergey's Manual of Determinative Bacteriology (1957), $7^{\text {th }}$ edn. Edited by R. S. Breed, E. G. D. Murray and N. R. SMITH. London: Baillière Tindall \& Cox.

Buchanan, R. E., Holt, J. G. \& Lessel, E. F. (1966). Index Bergeyana. Edinburgh: Livingstone.

Castelnuovo, G., Bellezza, G., Duncan, M. E. \& Asselineau, J. (1964). Étude sur les mycobactéries et les nocardiae. I: Constitution antigénique. II: Relations sérologique entre mycobactéries et nocardiae. III: Sensibilité aux phages. Annales de L'institut Pasteur 107, 824-844.

Cerbón, J. (1967). Taxonomic analysis of Nocardia. Revista latino-americana de microbiologia y parasitologia $9,65-68$.

Chamoiseau, G. \& Asselineau, J. (1970). Examen des lipides d'une souch de Nocardia farcinica: présence d'acides mycoliques. Compte rendu hebdomadaire des de l'Académie des Sciences D 270, 2603-2604.

ClaRK, J. B. \& HittLe, L. L. (1962). The utilization of various carbon compounds by Nocardia corallina and Nocardia asteroides. Proceedings of the Oklahoma Academy of Sciences 43, 249-254.

Deibel, R. H. \& Evans, J. B. (1960). Modified benzidine test for the detection of cytochrome-containing respiratory systems in micro-organisms. Journal of Bacteriology 79, 356-360.

Georg, L. K., Ajello, L., McDurmont, C. \& Hosty, T. S. (I96I). The identification of Nocardia asteroides and Nocardia brasiliensis. American Review of Respiratory Diseases 84, 337-347.

Gordon, R. E. (1966a). Some critieria for the recognition of Nocardia madurae (Vincent) Blanchard. Journal of General Microbiology 45, 355-364.

Gordon, R. E. (1966b). Some strains in search of a genus - Corynebacterium, Mycobacterium, Nocardia or what? Journal of General Microbiology 43, 329-343.

Gordon, R. E. (1967). The taxonomy of soil bacteria. In The Ecology of Soil Bacteria, pp. 293-321. Edited by T. R. G. Gray and D. Parkinson. Liverpool: Liverpool University Press.

Gordon, R. E. \& Horan, A. C. (I968). A piecemeal description of Streptomyces griseus (Krainsky) Waksman and Henrici. Journal of General Microbiology 50, 223-233.

Gordon, R. E. \& Minм, J. M. (1957). A comparative study of some strains received as nocardiae. Journal of Bacteriology 73, I5-27.

Gordon, R. E. \& MinM, J. M. (I959a). A comparison of Nocardia asteroides and Nocardia brasiliensis. Journal of General Microbiology 20, 129-1 35. 
Gordon, R. E. \& Miнm, J. M. (I959b). A comparison of four species of mycobacteria. Journal of General Microbiology 21, 736-748.

Gordon, R. E. \& MinM, J. M. (I96I). The specific identity of Jensenia canicruria. Canadian Journal of Microbiology 7, 108-110.

Gordon, R. E. \& Miнm, J. M. (1962a). Identification of Nocardia caviae (Erikson) nov.comb. Annals of the New York Academy of Sciences 98, 628-636.

Gordon, R. E. \& Mirm, J. M. (1962 b). The type species of the genus Nocardia. Journal of General Microbiology 27, I-ro.

Hugh, R. \& LeIFson, E. (I953). The taxonomic significance of fermentative versus oxidative metabolism of carbohydrates by various Gram-negative bacteria. Journal of Bacteriology 66, 24-26.

Jeffries, C. D., Holtman, D. F. \& Guse, D. G. (1957). Rapid method for determining the activity of microorganisms on nucleic acids. Journal of Bacteriology 73, 590-591.

Jones, J. G. \& Edington, M. A. (I968). An ecological survey of hydrocarbon-oxidizing micro-organisms. Journal of General Microbiology 52, 38I-390.

JONES, L. A. \& BRADLEY, S. G. (1964). Relationships among streptomycetes, nocardiae, mycobacteria and other actinomycetes. Mycologia 56, 505-5I3.

Juhasz, S. E. \& BöNICKE, R. (1965). Mycobacterium oder Nocardia pellegrino. Beiträge zur Klinik der Tuberkulose 130, I55-169.

KwAPInSKi, J. B. G. (1970). Serological taxonomy and relationships of Actinomycetales. In The Actinomycetales, pp. 345-369. Edited by H. Prauser. Jena: Gustav Fischer.

Lechevalier, H. A. \& Lechevalier, M. P. (1970). A critical evaluation of the genera of aerobic actinomycetes. In The Actinomycetales, pp. 393-405. Edited by H. Prauser. Jena: Gustav Fischer.

Lechevalier, H., Lechevalier, M. P. \& BeCKeR, B. (I966). Comparison of the chemical composition of cell-walls of nocardiae with that of other aerobic antinomycetes. International Journal of Systematic Bacteriology 16, I51-160.

Lechevalier, M. P., Horan, A. C. \& Lechevalier, H. (197I). Lipid composition in the classification of nocardiae and mycobacteria. Journal of Bacteriology 105, 31 3-318.

LecheVAlier, M. P. \& Lechevalier, H. (1971). Chemical composition as a criterion in the classification of aerobic actinomycetes. International Journal of Systematic Bacteriology 20, 435-444.

Mackinnon, J. E. \& Artagaveytia-Allende, R. C. (1956). The main species of pathogenic aerobic actinomycetes causing mycetomas. Transactions of the Royal Society of Tropical Medicine and Hygiene $\mathbf{5 0}^{\mathbf{0}}$ $3 \mathrm{I}-40$.

Magnusson, M. \& MARIAT, F. (1968). Delineation of Nocardia farcinica by delayed type skin reactions on guinea pigs. Journal of General Microbiology 5I, 15 I-1 58.

Mariat, F. (1958). Physiologie des actinomycètes aérobies pathogènes. Recherches sur l'activité protéolytique et sur la nutrition azotée et carbonée de Nocardia asteroides, N. brasiliensis, Streptomyces madurae, $S$. pelletieri et $S$. somaliensis. Mycopathologia et mycologia applicata 9, I I I-I 49 .

MARIAT, F. (1962). Critères de detérmination des principales espèces d'Actinomycètes aérobies pathogènes. Annales de la Société belge de médecine tropicale 4, 651-672.

Mariat, F. (I963). Activité uréasique des Actinomycètes aérobies pathogènes. Annales de L'institut Pasteur I05, 795-797.

Mariat, F. (1965). Étude comparitive de souches de Nocardia isolés de mycétomes. Annales de L'institut Pasteur 109, 90-104.

MCCLung, N. M. (1954). The utilization of carbon compounds by Nocardia species. Journal of Bacteriology $68,231-236$.

Mitchell, T. G. \& Shewan, J. M. (1968). Aspects of taxonomy with respect to biodeterioration. In Biodeterioration of Materials: Microbiological and Allied Aspects, pp. I 3-21. Barking: Elsevier Publishing Co. Ltd.

Mordarska, H. \& Modarski, M. (1969). Comparative studies on the occurrence of lipid A, diaminopimelic acid and arabinose in Nocardia cells. Archivum Immunologiae et Therapiae Experimentalis 17, 739-743.

Pier, A. C. \& Fichtner, R. E. (1971). Serologic typing of Nocardia asteroides by immunodiffusion. American Review of Respiratory Disease 103, 698-707.

Prauser, H. (1967). Contributions to the taxonomy of the Actinomycetales. Publications of the Faculty of the Sciences, J. E. Purkynĕ University, Brno K 40, 196-199.

Prauser, H. \& Falta, R. (1968). Phagensensibilität, Zellwandzusammensetzung und Taxonomie von Actinomyceten. Zeitschrift für allgemeine Mikrobiologie 8, 39-46. 
Prauser, H., Lechevalier, M. P. \& Lechevalier, H. (1970). Description of Oerskovia gen.n. to harbor Ørskov's motile Nocardia. Applied Microbiology 19, 534.

PridhaM, T. G. \& GotTlieb, D. (1948). The utilization of carbon compounds by some actinomycetales as an aid for species determination. Journal of Bacteriology 56, 107-1 I4.

RAYMOND, R. L., JAMISON, V. W. \& HuDSON, J. O. (I967). Microbial hydrocarbon co-oxidation. I. Oxidation of mono- and dicyclic hydrocarbons by soil isolates of the genus Nocardia. Applied Microbiology 15, $857-865$.

SIERRA, G. (1957). A simple method for the detection of lipolytic activity of microorganisms and some observations on the influence of the contact between cells and fatty substrates. Antonie van Leeuwenhoek 23, I5-22.

SNEATH, P. H. A. (1957). The application of computers to taxonomy. Journal of General Microbiology 17, 20I-226.

SNeATH, P. H. A. (I966). Identification methods applied to Chromobacterium. In Identification Methods for Microbiologists, Part A, pp. 15-20. Edited by B. M. Gibbs and F. A. Skinner. London and New York: Academic Press.

SNeAth, P. H. A. (1968). Vigour and pattern in taxonomy. Journal of General Microbiology 54, I-II.

SNeATh, P. H. A. \& Skerman, V. B. D. (1966). A list of type and reference strains of bacteria. International Journal of Systematic Bacteriology I6, I-I33.

Sneath, P. H. A. \& Stevens, M. (1967). A divided petri dish for use with multipoint inoculators. Journal of Applied Bacteriology 30, 495-497.

Society of AMERICAN BACterIologists (1957). Manual of Microbiological Methods. New York: McGrawHill.

Sokal, R. R. \& Michener, C. D. (1958). A statistical method for evaluating systematic relationships. Kansas University Science Bulletin 38, I409-I438.

Sokal, R. R. \& Sneath, P. H. A. (1963). Principles of Numerical Taxonomy. San Francisco: Freeman.

Stanier, R. Y., Palleroni, N. J. \& Doudoroff, M. (I966). The aerobic pseudomonads: a taxonomic study. Journal of General Microbiology 43, 159-27I.

SteEL, K. J. (196I). The oxidase reaction as a taxonomic tool. Journal of General Microbiology 25, 297-306.

Stevenson, I. L. (1967). Utilization of aromatic hydrocarbons by Arthrobacter spp. Canadian Journal of Microbiology 13, 205-21I.

Sukapure, R. S., Lechevalier, M. P., Reber, H., Higgins, M. L., Lechevalier, H. A. \& Prauser, H. (1970). Motile nocardioid Actinomycetales. Applied Microbiology I9, 527-533.

TACQUET, A. (1962). Techniques récentes d'identification des mycobactéries. Annales de la Société belge de médecine tropicale 4, 383-402.

Tsukamura, M. (1966). Adansonian classification of mycobacteria. Journal of General Microbiology 45, 253273.

Tsukamura, M. (1969). Numerical taxonomy of the genus Nocardia. Journal of General Microbiology 56, $265-287$.

VeldKAMP, H. (1955). A study of the aerobic decomposition of chitin by micro-organisms. Mededelingen van de Landbouwhoogeschool te Wageningen. 55, 127-174.

YAMAGUCHI, T. (1965). Comparison of the cell-wall composition of morphologically distinct actinomycetes. Journal of Bacteriology 89, 444-453. 